SERI/STR-232-3569

DE89009493

\title{
Design and Operation of an Outdoor Microalgae Test Facility
}

\section{Final Subcontract Report}

\author{
J. C. Weissman \\ D. M. Tillet \\ R. P. Goebel
}

Prepared under Subcontract No. XK-7-06113-1
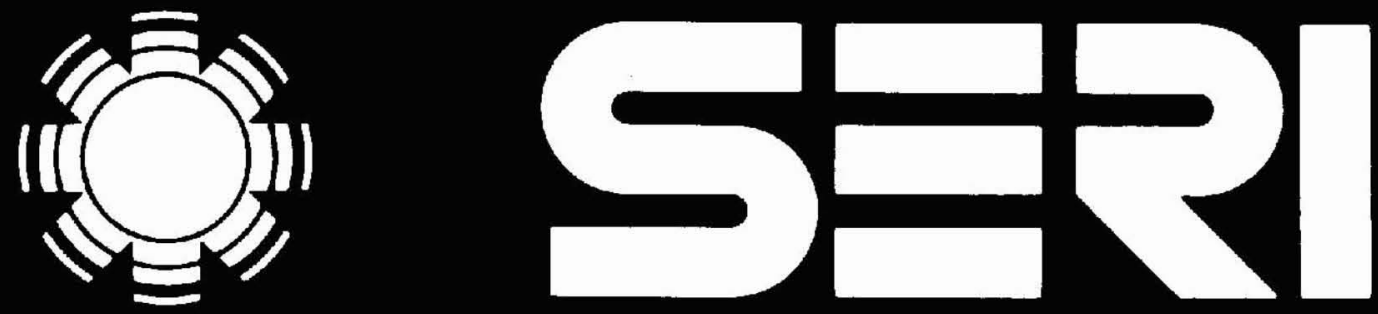

Solar Energy Research Institute A Division of Midwest Pesearch institute

1617 Cole Boulevard

Golden, Colorado 80401

Operated for the

U.S. Department of Energy

under Contract No. DE-AC02-83CH10093 


\section{Design and Operation of an Outdoor Microalgae Test Facility}

\section{Final Subcontract Report}

J. C. Weissman

D. M. Tillett

R. P. Goebel

October 1989

SERI Technical Monitor: W. Bollmeier

Prepared under Subcontract No. XK-7-06113-1

Solar Energy Research Institute

A Division of Midwest Research Institute

1617 Cole Boulevard

Golden, Colorado 80401-3393

Prepared for the

U.S. Department of Energy

Contract No. DE-AC02-83CH10093 


\section{NOTICE}

This report was prepared as an account of work sponsored by an agency of the United States government. Neither the United States government nor any agency thereof, nor any of their employees, makes any warranty, express or implied, or assumes any legal liability or responsibility for the accuracy, completeness, or usefulness of any information, apparatus, product, or process disclosed, or represents that its use would not intringe privately owned rights. Reference herein to any specific commercial product, process, or service by trade name, trademark, manufacturer, or otherwise does not necessarily constitute or imply its endorsement, recommendation, or favoring by the United States government or any agency thereof. The views and opinions of authors expressed herein do not necessarily state or reflect those of the United States government or any agency thereof.

Printed in the United States of America

Available from:

National Technical Information Service

U.S. Department of Commerce

5285 Port Royal Road

Springfield, VA 22161

Price: Microfiche A01

Printed Copy AO4

Codes are used for pricing all publications. The code is determined by the number of pages in the publication. Information pertaining to the pricing codes can be found in the current issue of the following publications which are generally available in most libraries: Energy Research Abstracts (ERA): Govern. ment Reports Announcements and Index (GRA and I); Scientific and Technical Abstract Reports (STAR); and publication NTIS-PR-360 available from NTIS at the above address. 


\section{PREFACE}

The Solar Fuels Research Division of the Solar Energy Research Institute (SERI) manages the Aquatics Species Program for the U.S. Department of Energy (DOE) Biofuels and Municipal Waste Technology Division under DOE Contract No. XK-7-06113-1. A major emphasis of this program is to develop the technology for mass culture of microalgae in large outdoor ponds for conversion of the microalgae to liquid fuels, such as diesel.

This is the final report submitted by Microbial Products, Inc., in partial completion of Contract No. XK-7-06113-1. 


\section{ACKNOWLEDGMENTS}

This work was supported in part by the New Mexico Research and Development Institute with a grant administered through the city of Roswell, N. Mex. We thank Dr. Larry Icerman, director of the Institute; John Capps, the Roswell assistant city manager; and Charles Sparnon, the Roswell utilities manager, for their efforts.

The authors would like to acknowledge the contributions of Ronald S. Sturdevant in both the fabrication of the experimental systems and their operation. In addition, we thank Gary Beatty, Eddy Trujillo, and Ken Irvin for their aid and support. 


\section{SUMMARY}

\section{Objective}

The objective of this project is to establish and operate a facility in the American Southwest to test the concept of producing microalgal biomass as a feedstock for the production of liquid fuels. The site chosen for this project was an existing water research station in the city of Roswell in southeastern New Mexico. The climate and water resources are representative of those in the Southwest. Fulfillment of this objective includes testing specific designs, modes of operation, and strains of microalgae; proposing and evaluating modifications to technological concepts; and assessing the progress in meeting cost objectives set for the Aquatic Species Program (ASP).

The objectives during the first year were to evaluate outdoor production performance of prescreened species of microalgae in six small-scale reactors $\left(3 \mathrm{~m}^{2}\right)$ and to begin the development of a larger-scale facility. The objectives during the second year were to continue evaluating biomass and lipid productivity in the $3-\mathrm{m}^{2}$ system, to finish installation of two 0.1-ha raceways, to perform an engineering analysis of the system, and to begin long-term production of algal biomass.

\section{Discussion}

In the $3-\mathrm{m}^{2}$ ponds, 15 strains of microalgae were tested for productivity potential. Six of the strains grew well enough to evaluate. The small ponds were operated for almost 11 months, allowing annual productivity to be estimated. Based on this year's growth, that average is at least $16 \mathrm{~g}$ ash free dry weight (AFDM) $/ \mathrm{m}^{2} / \mathrm{d}$ of algal biomass. Improvement during several critical months, during which insolation is high but temperatures are variably cool, could easily bring this average above $20 \mathrm{~g} \mathrm{AFDM} / \mathrm{m}^{2} / \mathrm{d}$. To significantly improve productivities above that will require an understanding of why shortterm productivities exceed $50 \mathrm{~g} \mathrm{AFDM} / \mathrm{m}^{2} / \mathrm{d}$ during the summer when averages are only $30 \mathrm{~g} \mathrm{AFDM} / \mathrm{m}^{2} / \mathrm{d}$, and selection of organisms that perform better at temperatures between $5^{\circ}$ and $10^{\circ} \mathrm{C}$.

The growth response to lowered $\mathrm{pCO}_{2}$ was also studied. When productivity of $\mathrm{CO}_{2}$ replete cultures $\left(285 \mu \mathrm{m} \mathrm{CO}\right.$ ) averaged about $20 \mathrm{~g} \mathrm{AFDM} / \mathrm{m}^{2} / \mathrm{d}$, lowering $\mathrm{pCO}_{2}$ to $20 \mu \mathrm{m}$ at a pH of 8.3 only lowered productivity 15\%. That the decrease was small is significant, since loss of inorganic carbon (via outgassing) is almost negligible at this $\mathrm{CO}_{2}$ concentration. Through continued study, we will determine whether the reduction is so modest when productivity is at a higher level (e.g., $35 \mathrm{~g} \mathrm{AFDM} / \mathrm{m}^{2} / \mathrm{d}$ ).

After the two 0.1-ha raceways were completed, the system was evaluated in terms of effectiveness of mixing; energy losses in fluid motion along channels, through bends and sumps; efficiency of the paddle wheel as a mixing device; and efficiency of the carbonation sumps in getting $\mathrm{CO}_{2}$ absorbed into the water. We found that uneven grading of the pond bottoms limited the shallowness of the ponds to more than $15 \mathrm{~cm}$, and probably to $20 \mathrm{~cm}$. At lower depths, in-pond sedimentation of biomass was a significant problem. In general, velocity profiles were as expected: fairly uniform across the channel, decreasing quickly within a few centimeters of the pond bottom, and highly nonuniform around 
bends, sumps, and at the paddle wheel intake. The large velocity head created at this intake lowered the mixer efficiency at high mixing rates. Mixing power required to overcome friction was close to that estimated previously. Adjustments to these estimates were, however, required to account for losses in bends and sumps. The smooth, plastic-lined channels had a Manning's roughness of 0.0100 , while the clay-lined, rockcovered channels had a roughness of 0.0173 .

The countercurrent operation of the carbonation sumps allowed a $\mathrm{CO}_{2}$ injection efficiency of above $80 \%$, even without gas recycle. To achieve the $90+\%$ desired, recycle of the gas that escapes above the sump will be required. The overall efficiency for utilization of $\mathrm{CO}_{2}$ was $60 \%$. At pH 7.5 to $7.8,25 \%$ of the $\mathrm{CO}_{2}$ absorbed in the carbonation sumps was lost to the atmosphere by outgassing through the pond surface. Operating at $\mathrm{pH} 8$ to 8.3 should reduce this to less than $10 \%$.

Operation of the two 0.1-ha raceways began in August 1988. Productivities in the lined pond were $80 \%$ of those in the $3-\mathrm{m}^{2}$ fiberglass ponds while those of the unlined pond were only $60 \%$. In-pond sedimentation of biomass appears to have been the major difference among the three types of ponds, being negligible in the $3-\mathrm{m}^{2}$ ponds and worst in the unlined pond. Operating at greater depth and placing additional flow deflectors will be used to alleviate this problem. $\mathrm{CO}_{2}$ outgassing was greater from the unlined pond, due to the faster rate of renewal of surface resulting from greater bottom roughness. Power consumption was also greater, especially when compared to the effectiveness of the mixing in keeping cells suspended. Finally, water loss was somewhat greater, primarily due to leaks. These leaks should be correctable. Percolation was minimal, after an initial month of operation during which time the pores sealed.

\section{Conclusions}

Several strains of microalgae have been found to grow well in the outdoor environment of southeastern New Mexico. Productivities in small test ponds were as high as $50 \mathrm{~g} \mathrm{AFDM} / \mathrm{m}^{2} / \mathrm{d}$ during the best summer days, and averaged over $16 \mathrm{~g} \mathrm{AFDM} / \mathrm{m}^{2} / \mathrm{d}$ over the entire year. Several strains have been found that tolerate freezing conditions during the winter. Initial scaleup to $1000 \mathrm{~m}^{2}$ was initiated. The significant scaleup problem encountered involved the effectiveness of the mixing system in keeping cells suspended. Strategies to improve the mixing have been developed and will be tested during the next subcontract period. Efficiency of the utilization of mixing power, water, and $\mathrm{CO}_{2}$ were all found to be good, although improvements will still be necessary. 


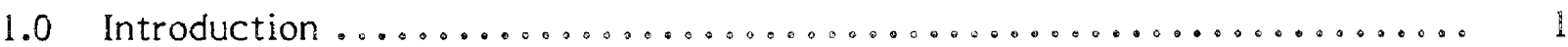

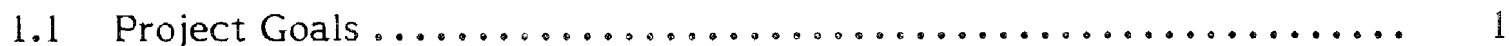

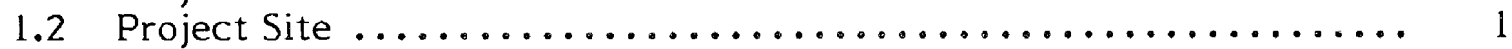

1.3 Goals for the Current Year $\ldots \ldots \ldots \ldots \ldots \ldots \ldots \ldots \ldots \ldots \ldots \ldots \ldots \ldots$

2.0 Completion of Large-Scale System $\ldots \ldots \ldots \ldots \ldots \ldots \ldots \ldots \ldots \ldots \ldots$

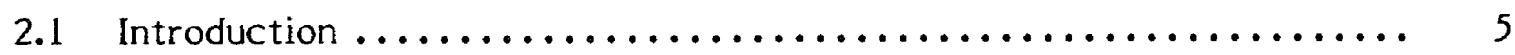

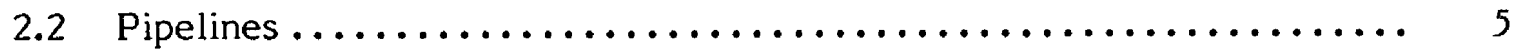

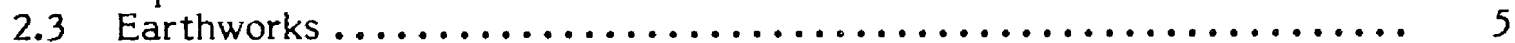

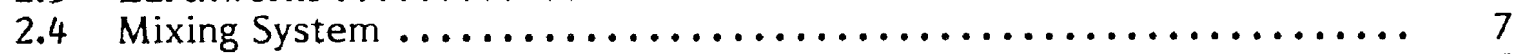

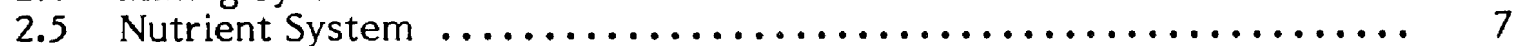

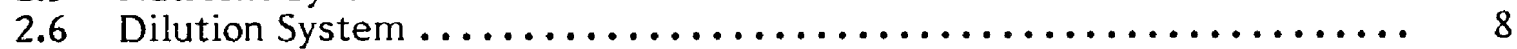

2.7 Carbonation System $\ldots \ldots \ldots \ldots \ldots \ldots \ldots \ldots \ldots \ldots \ldots \ldots \ldots \ldots \ldots \ldots$

3.0 Large-Scale System Engineering Analysis ...................... 9

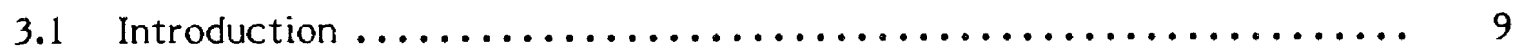

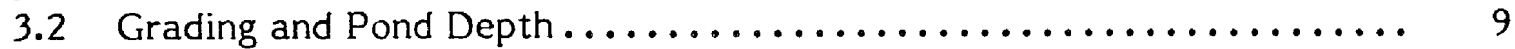

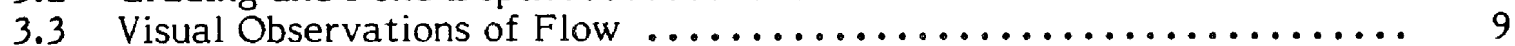

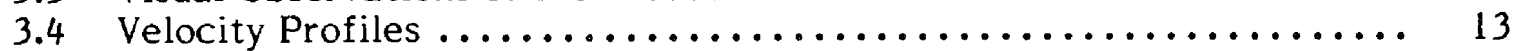

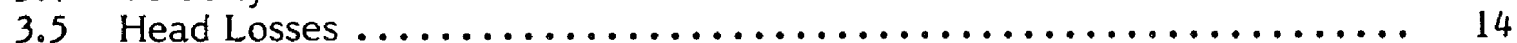

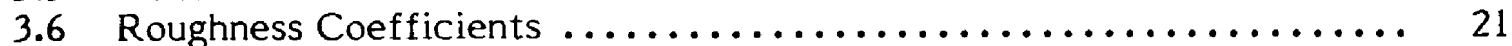

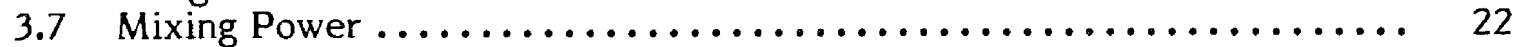

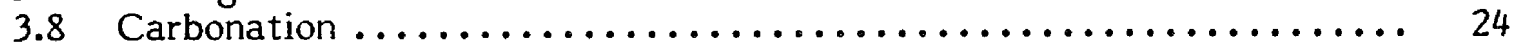

4.0 Operation of the Large-Scale System $\ldots \ldots \ldots \ldots \ldots \ldots \ldots \ldots \ldots \ldots \ldots \ldots$

5.0 Operation of the Small-Scale System $\ldots \ldots \ldots \ldots \ldots \ldots \ldots \ldots \ldots \ldots \ldots$

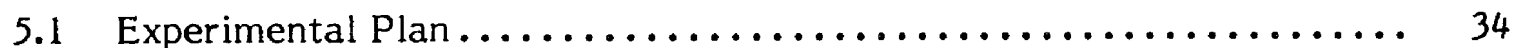

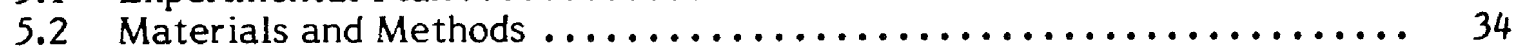

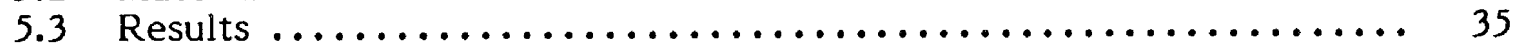

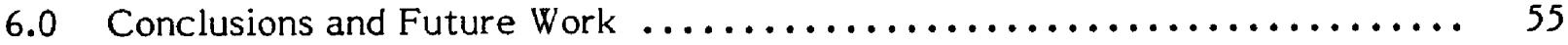

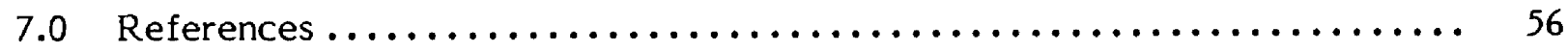




\section{LIST OF FIGURES}

1-1 Location of Roswell, N. Mex. $\ldots \ldots \ldots \ldots \ldots \ldots \ldots \ldots \ldots \ldots \ldots \ldots, 2$

2-1 Large-scale system pond layout $\ldots \ldots \ldots \ldots \ldots \ldots \ldots \ldots \ldots \ldots \ldots \ldots, 6$

3-1 Depth profiles along channel bottoms for average pond depths of $13.7 \mathrm{~cm}$ in North (lined) pond and $13.5 \mathrm{~cm}$ in South (unlined) pond.

3-2 Depth profiles along channel bottoms for North (lined) pond (average depth of $13.7 \mathrm{~cm}$ ) at five locations across channel

3-3 Depth profiles along channel bottoms for South (unlined) pond (average depth of $13.5 \mathrm{~cm}$ ) at five locations across channel $. . \ldots \ldots \ldots . .$.

3-4 Velocity-depth profiles in North (lined) pond at paddle wheel rotation settings of $0.3(2.7 \mathrm{rpm})$ and $0.5(4.4 \mathrm{rpm}) \ldots \ldots \ldots \ldots \ldots$

3-5 Velocity-depth profiles in Nor th (lined) pond at paddle wheel rotation settings of $0.7(6.1 \mathrm{rpm})$ and $0.9(7.8 \mathrm{rpm}) \ldots \ldots \ldots \ldots \ldots \ldots . . .16$

3-6 Velocity-depth profiles in South (unlined) pond at paddle wheel rotation settings of $0.3(2.7 \mathrm{rpm})$ and $0.5(4.4 \mathrm{rpm}) \ldots \ldots \ldots \ldots \ldots \ldots \ldots$

3-7 Velocity-depth profiles in South (unlined) pond at paddle wheel rotation settings of $0.7(6.1 \mathrm{rpm})$ and $0.9(7.8 \mathrm{rpm})$

3-8 Profiles of depth-averaged velocity across the return channel (1.4-m upstream from sump) in each 0.1 -ha raceway $\ldots \ldots \ldots \ldots \ldots \ldots . . .$.

3-9 Mixing power as a function of average water velocity in

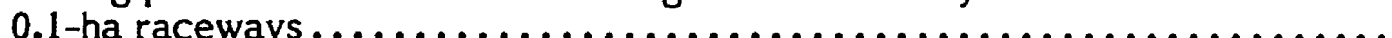

5-1 Daily total insolation at the Roswell Test Facility, N. Mex. .............

5-2 Maximum and minimum air temperatures at the Roswell Test Facility, N. Mex. ................................... 38

5-3 Maximum and minimum temperatures in unheated ponds $\ldots \ldots \ldots \ldots \ldots \ldots . \quad 39$

5-4 Productivity of Amphora sp. RTF $\ldots \ldots \ldots \ldots \ldots \ldots \ldots \ldots \ldots \ldots \ldots, 42$

5-5 Harvested productivity of $T$. suecica and Cyclotella sp. RTF ........... 43

5-6 Harvested productivity of C. muelleri CHAET9 and C. muelleri CHAET63....................................... 44

5-7 Harvested productivity of $M$. minutum MONOR2.................. 45

5-8 Productivity of nitrogen-depleted induction batches of C. muelleri CHAET63..................................... 


\section{LIST OF FIGURES (Concluded)}

Page

5-9 Productivity of nitrogen-depleted induction batches of C. muelleri CHAET9.

5-10 Productivity of nitrogen-depleted induction batches of M. minutum MONOR2

5-11 Productivity of nitrogen-depleted induction batches of Cyclotella sp. RTF.

5-12 Productivity of nitrogen-depleted induction natches of T. suecica TETRA1.

5-13 Productivity of nitrogen-depleted induction batches of Amphora sp. RTF 


\section{LIST OF TABLES}

$\underline{\text { Page }}$

1-1 Mineral Composition of Water Resources at RTF

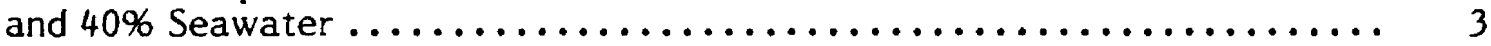

1-2 Facility Development Plan $\ldots \ldots \ldots \ldots \ldots \ldots \ldots \ldots \ldots \ldots \ldots \ldots \ldots \ldots \ldots$

2-1 Mixing System Design Criteria $\ldots \ldots \ldots \ldots \ldots \ldots \ldots \ldots \ldots \ldots \ldots \ldots \ldots$

3-1 $\quad 0.1$-ha Pond Depths and Deviations $\ldots \ldots \ldots \ldots \ldots \ldots \ldots \ldots \ldots \ldots \ldots$

3-2 Average Depths, Velocities, and Flow Rates 1.4-m Upstream from

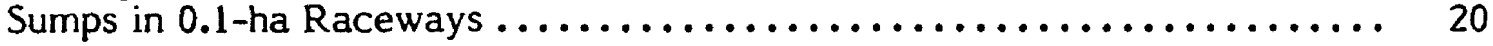

3-3 Average Velocities in 0.1 -ha Raceways $\ldots \ldots \ldots \ldots \ldots \ldots \ldots \ldots \ldots \ldots$

3-4 Total Head Loss (CM) for Each Section of 0.1 -ha Raceways .......... 21

3-5 Manning's Roughness Coefficients for 0.1 -ha Raceways ............. 22

3-6 Mixing Power Requirements for 0.1 -ha Raceways $\ldots \ldots \ldots \ldots \ldots \ldots \ldots$

3-7 pH, Partial Pressure of $\mathrm{CO}_{2}\left(\mathrm{pCO}_{2}\right)$, and TIC Relationship for RTF Water26

3-8 Summary of Carbonation Tests in Sump ..................... 29

3-9 Summary of Carbonation Tests in $600-\mathrm{L}$ Tank .................. 29

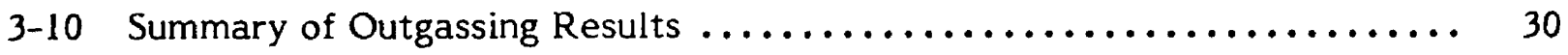

4-1 Large-scale System Productivity $\ldots \ldots \ldots \ldots \ldots \ldots \ldots \ldots \ldots \ldots \ldots \ldots \ldots \ldots \ldots$

4-2 Average Daily Water Loss from Large-scale Ponds ............... 32

4-3 Carbon Utilization Efficiency in Lined Pond $\ldots \ldots \ldots \ldots \ldots \ldots \ldots \ldots \ldots$

5-1 Monthly Productivity Results from $3-m^{2}$ Algal Cultures ............ 40

5-2 Productivity of Algal Strains Cultivated in $3 \mathrm{~m}^{2} \ldots \ldots \ldots \ldots \ldots \ldots$

5-3 Effects of Heating on Algal Productivity in $3-m^{2}$ Ponds $\ldots \ldots \ldots \ldots$

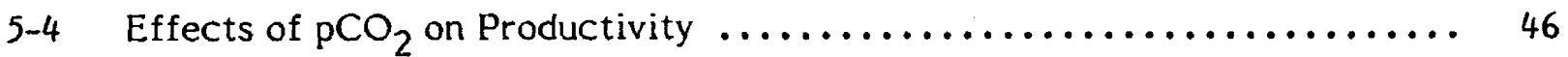

5-5 Effects of Dilution Rate on Productivity $\ldots \ldots \ldots \ldots \ldots \ldots \ldots \ldots \ldots$

5-6 Productivities of Nutrient-sufficient and -deficient

Algal Cultures .................................. 48 


\subsection{INTRODUCTION}

\subsection{Project Goals}

The overall objectives of this project are to develop and to operate a test facility in the American Southwest to evaluate microalgal productivities and to examine the problems and potential of scaling up and operating large microalgal production systems. This project includes testing specific designs, modes of operation, and strains of microalgae; proposing and evaluating modifications to technological concepts; and assessing the progress in meeting cost objectives of the Aquatic Species Program (ASP).

The objective during the first year of the project (March 9, 1987, to March 11, 1988) was to evaluate the outdoor production performance of prescreened microalgae species in six small-scale reactors $\left(3 \mathrm{~m}^{2}\right)$ and to begin the development of a larger-scale facility (Weissman et al., 1988a).

\subsection{Project Site}

The project is located at an established water research facility in the city of Roswell in the southeastern part of New Mexico (Figure 1-1). The site is representative of those that may be available for construction of an actual production plant. It is characterized by high insolation, low precipitation, flat land, and an abundant supply of highly saline groundwater. Much of the infrastructure required for this type of project was already in place: triple-lined evaporation ponds for disposal of pond effluents, land at very affordable rental rates, and laboratory and office space. In addition, a chemical analysis laboratory exists, much of which is common space for the tenants of the facility.

Two abundant water respurces are available at the New Mexico site: city water (at $\$ 326 /$ acre-ft or $\$ 0.26 / \mathrm{m}_{3}^{3}$ ) and saline groundwater (800 gpm at a pumping cost of about $\$ 75 /$ acre-ft or $\left.\$ 0.012 / \mathrm{m}^{3}\right)$. The mineral composition of each is given in Table $1-1$. The groundwater has a salinity similar to $40 \%$ seawater, differing primarily in that it contains about one-third as much magnesium and twice as much calcium. Growth on this water would be representative of growth on high-calcium, low-alkalinity waters similar to seawater and Type I groundwaters (Barclay et al., 1987). It is believed that this water resource is typical of most saline aquifers in the Southwest.

The Roswell Test Facility (RTF) has flat, usable land around the main laboratories. A small part of this area is currently used to operate our six small-scale experimental ponds. One mile east of this location are 36 ha of triple-lined evaporation ponds arranged as a set of three 12-ha units. The large-scale system was constructed within one-half of one of these ponds, leaving room for expansion in the future. Another 12-ha evaporation unit is used for evaporative disposal of the growth pond effluents. This preexisting disposal system at the RTF is one of the major attractions of the facility. Construction of an evaporation system of the requisite size, from two to five times the growth pond area, would have been a major cost item.

At the beginning of the project, a plan was developed for establishing the test facilities during the first several years. The plan was based on total funds of about $\$ 300,000$ for fabrications. The schedule of development and the corresponding costs are given in Table 1-2. The facility now includes a small-scale system comprising six $3-\mathrm{m}^{2}$ ponds, a $50-\mathrm{m}^{2}$ inoculum pond, two 0.1 -ha growth ponds (one lined with earthen materials, one with a membrane), and the infrastructural development required (power, storage sheds, water lines, etc.). A large, 0.5-ha pond and a harvesting system based on flocculationflotation have not yet been built. 


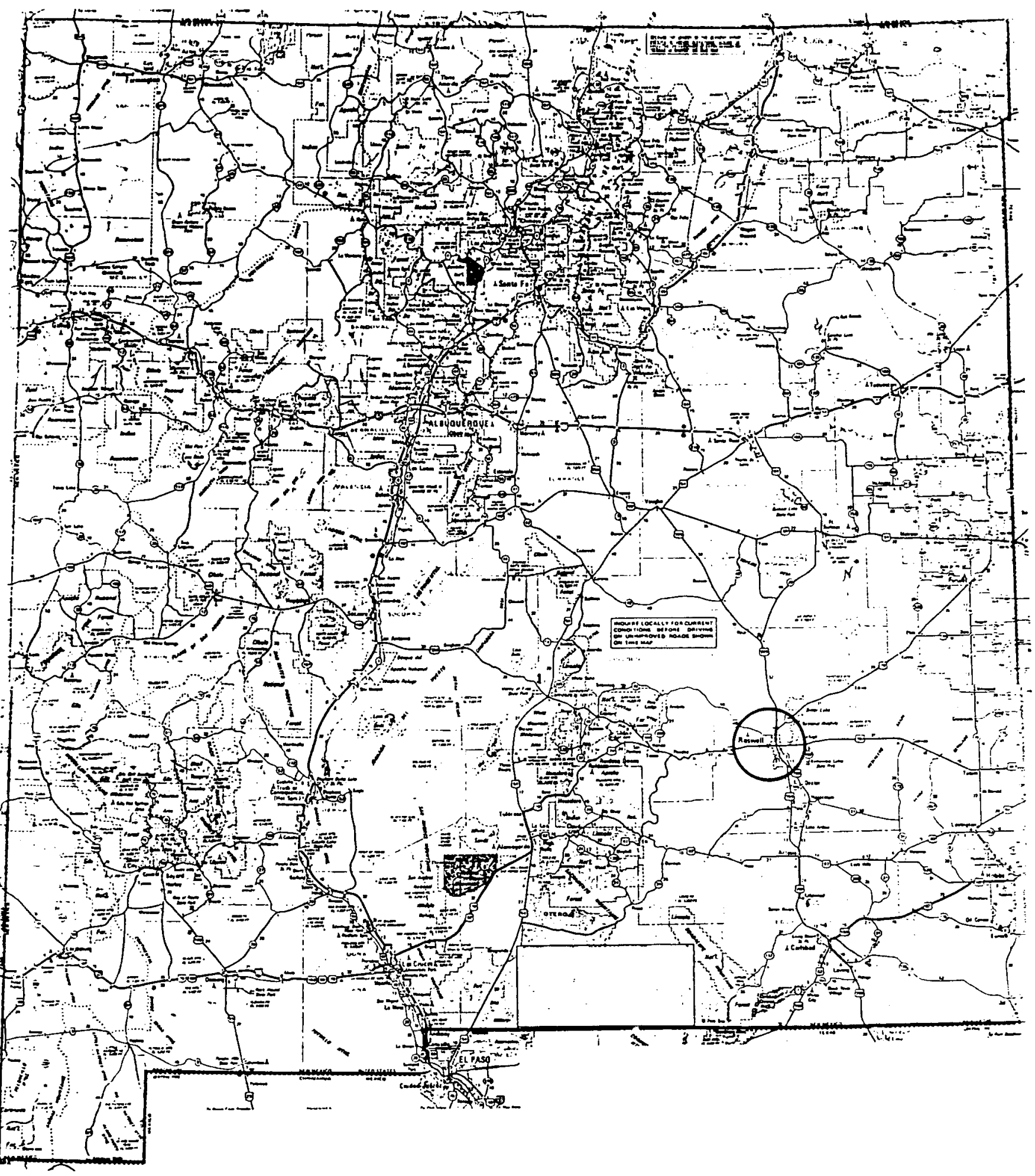

Figure 1-1. Location of Roswell, N. Mex. 
Table 1-1. Mineral Composition of Water Resources at RTF and $40 \%$ Seawater

\begin{tabular}{lccr}
\hline & City Water & SaW & $\begin{array}{c}40 \% \\
\text { Seawater }\end{array}$ \\
\hline Sodium & 35 & 4,500 & 4,800 \\
Potassium & 1 & 23 & 120 \\
Calcium & 152 & 537 & 160 \\
Magnesium & 46 & 172 & 475 \\
Chloride & 53 & 6,870 & 7,600 \\
Sulfate & 320 & 1375 & 920 \\
Bicarbonate & 229 & 192 & 78 \\
Silicon & 1.3 & 1.7 & \\
TDS & 705 & 13,620 & 14,000 \\
pH & 7.7 & 7.2 & \\
\hline
\end{tabular}

Values are $\mathrm{mg} / \mathrm{L}$.

RTF water analysis courtesy of G. Beatty, RTF chemist.

\subsection{Goals for the Current Year}

During the second year (March 12,1988, to March 11, 1989) the objectiyes of the project were to continue evaluating biomass and lipid productivity in the $3-\mathrm{m}^{2}$ pond system, to finish installation of the two 0.1-ha raceways, to evaluate the large system in terms of hydraulics and carbonation, and to begin year-round operation of the large system. Each of these tasks is discussed in a separate section of this report. 
Table 1-2. Facility Development Plan

Ist Year:

Small-scale system (six $3-\mathrm{m}^{2}$ ponds)

$\$ 29,000$

Large-scale system

Water to site

Power to site

One 0.1 -ha growth pond (membrane-lined)

One 0.1 -ha growth pond (earth-lined)

Power distribution network

Engineering

TOTAL:

$$
\begin{array}{r}
23,500 \\
5,600 \\
54,000 \\
46,100 \\
2,700 \\
3,500 \\
\hline 164,400
\end{array}
$$

2nd Year:

Inoculum pond $-50 \mathrm{~m}^{2}$

Chemical storage shed

5,000

Power distribution network

2,000

Engineering

3,400

500

TOTAL:

$\$ 10,900$

Subsequent Years:

One 0.5-ha growth pond (earth-lined)

89,300

Electrical distribution network

4,600

Harvesting system (for all large ponds)

38,250

Engineering

3,600

TOTAL:

$\$ 135,750$

Note: Does not include labor by project personnel. 


\subsection{COMPLETION OF LARGE-SCALE SYSTEM}

Much of this section was described in the last annual report (Weissman et al., 1988a). It is repeated here for the convenience of the reader and extended to describe any changes made during completion of the system.

\subsection{Introduction}

The layout of the large-scale system is shown in Figure 2-1. The system consists of two 0.1 -ha growth ponds and one $50-\mathrm{m}^{2}$ pond, along with the necesssary mixing, dilution, and nutrient systems. The growth ponds have a capacity of $150 \mathrm{~m}^{3}$ at the nominal operating depth of $0.15 \mathrm{~m}$. The North pond (the lined pond) is lined with a plastic membrane, and the South pond (the unlined pond) is lined with crushed rock over clay. The channel length-to-width (L/W) ratio of 11 was chosen as a compromise between scaleup considerations (larger ponds would typically have a higher $\mathrm{L} / \mathrm{W}$ ratio) and the desire to have reasonably wide channels for studying bend hydraulics and mixing systems. The final choice in fact approximates that of a projected 4.0-ha pond, which would be somewhat constrained in length by the site.

\subsection{Pipelines}

The source of dilution water for the large-scale system is the deep well at the RTF, the same water used in the small-scale system. A 15.2-cm (6-in.) line (Class 125 PVC) was installed between the test facility and the pond site, a distance of approximately $1280 \mathrm{~m}$. This line has a capacity of about $120 \mathrm{~m}^{3} / \mathrm{h}(2000 \mathrm{~L} / \mathrm{min})$, sufficient to operate both the two 0.1-ha ponds and a future 0.5-ha pond. The two 0.1-ha ponds are operating solely on artesian presssure. A 7.6-cm (3-in.) freshwater line was also installed, with a capacity of about $36 \mathrm{~m}^{3} / \mathrm{h}(600 \mathrm{~L} / \mathrm{min})$, to allow blending of the two water types and to have fresh water at the site. As shown in Figure A-2, the pipelines tee into a main "utility corridor," which runs along the ends of the 0.1 -ha growth and $50-\mathrm{m}^{2}$ inoculum ponds and then over to evaporation pond $\mid ⿰ 2$, which will take waste from the system. The utility corridor contains all supply, harvest, and drain piping, as well as electrical and $\mathrm{CO}_{2}$ lines. Piping at the south end of the utility corridor was terminated to allow expansion to additional ponds.

\subsection{Earthworks}

This phase of the construction involved removing the existing vegetation, placing and compacting fill, and grading the fill material to the required slope. Placing, compacting, and grading the fill material was difficult because of soft spots at various locations on the pad. A test hole revealed groundwater at about $1 \mathrm{~m}$ below the level of the final grade. As will be discussed in Section 3, the limited ability to grade has had some consequences for pond hydraulics. Work may be required, during the next subcontract period, to make the grade more uniform.

On this scale, we determined that a continuous slope in the direction of flow (corresponding to the head losses at the nominal flow velocity) was impractical, since the total head loss, even at $30 \mathrm{~cm} / \mathrm{s}$, was only about $4 \mathrm{~cm}$. To do so would have required four changes in slope over the width of the pad, adding substantially to the cost, and probably could not have been done with sufficient accuracy given the difficulties encountered. Instead, the entire pad was graded to drain toward the west at a slope of 0.0006 , corresponding to about $4.5 \mathrm{~cm}$ over the length of the pond. This approach makes it easier to drain ponds, although it causes the culture depth to vary (in this case, $\pm 10 \%$ from nominal) as it moves around the pond. This, in turn, makes analysis of the hydraulics 


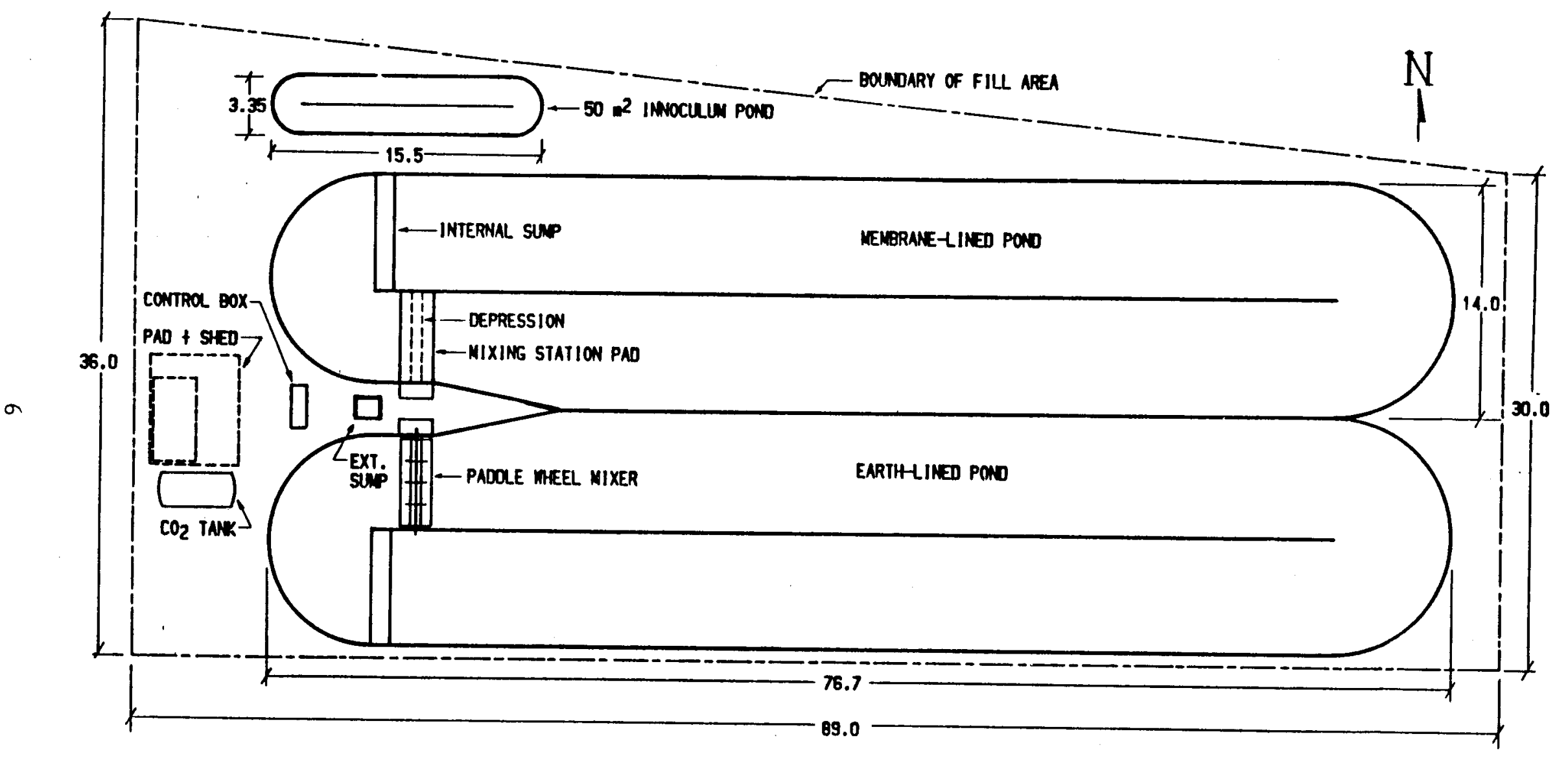

Figure 2-1. Large-scale system pond layout 
more complicated, since conditions of uniform flow can prevail only in the return channel.

\subsection{Mixing System}

Design criteria for the mixing system are listed in Table $2-1$. The choice of $42 \mathrm{~cm} / \mathrm{s}$ as the maximum mixing velocity was somewhat arbitrary, since this speed was about twice the normal mixing speed. The cost of designing for even greater speeds is high, given the cubic relationship between mixing speed and input power. (The details of the paddle wheel mixing system were given previously in Weissman et al. [1988a].) The paddle wheel and drive systems were installed during this project year.

The paddle wheel is driven directly by a speed reducer, which is belt-driven by a motor/ variable speed unit. A $1.12-\mathrm{kW}(1.5-\mathrm{hp})$ motor is face mounted to the variable speed unit (Beier Variator N2AXCY), which permits a 3:1 variation at the turn of a handle. Lower speeds are possible by changing the pitch diameter of the variable pitch pulley mounted on the output shaft. A V-belt couples this unit with the input of the two-stage cycloidal speed reducer (Cyclo 非165/11, 210:1 ratio). The speed reducer input pulley incorporates an adjustable torque limiter (American Autogard 409) that disengages upon overload. The output shaft drives the paddle wheel through a jaw coupling (Browning JS7Q). A direct drive between speed reducer and paddle wheel was chosen. In larger ponds, the two would typically be coupled with sprockets and chain, designed to reduce the speed by an additional $3: 1$ or $4: 1$, allowing a smaller and less expensive speed reducer to be used. As will be discussed in Section 3, this choice of drive had a distinct disadvantage: the power consumption of the reduction system and the inefficiency of a large motor operated at low rpm coupled to produce a large, no-load power. This made the overall efficiency of the drive system very low. For research purposes, however, the flexibility gained outweighs this reduced efficiency.

\subsection{Nutrient System}

The nutrient system was installed during the fall of 1988. Nutrients are mixed in concentrated solutions and fed into the dilution lines. The following nutrients and their respective mixing tank sizes are used: silica (as sodium metasilicate pentahydrate),

Table 2-1. Mixing System Design Criteria

\begin{tabular}{lccl}
\hline \multicolumn{1}{c}{ Parameter } & Nominal & Maximum & Units \\
\hline Width at channel & 6.85 & 6.85 & $\mathrm{~m}$ \\
Width at paddle wheel & 4.93 & 4.93 & $\mathrm{~m}$ \\
Paddle wheel efficiency & 0.6 & 0.6 & \\
Drive efficiency & 0.6 & 0.6 & \\
Manning roughness & 0.018 & 0.018 & $\mathrm{~cm} / \mathrm{s}$ \\
Velocity in channel & 20.0 & 42.0 & $\mathrm{~cm} / \mathrm{s}$ \\
Velocity at paddle wheel & 28.0 & 58.0 & $\mathrm{~cm}$ \\
Head loss & 1.8 & 8.0 & $\mathrm{~W}$ \\
Hydraulic power & 43.0 & 402.0 & $\mathrm{~W}$ \\
Total power & 121.0 & 1120.0 & $\mathrm{rpm}$ \\
Paddle wheel speed & 4.0 & 8.4 & $\mathrm{~N}-\mathrm{m}$ \\
Paddle wheel torque & 171.0 & 765.0 & \\
\hline
\end{tabular}


$1000 \mathrm{~L}$; urea, $375 \mathrm{~L}$; phosphate (as potassium phosphate dibasic), to be added to urea tank; iron (as ferrous sulfate slurry), $200 \mathrm{~L}$; and sulfuric acid, to neutralize the sodium metasilicate, $190 \mathrm{~L}$ drum. Nutrient solutions will be mixed with deionized water to prevent formation of precipitates. Deionized water is produced by a small reverse-osmosis unit (Kiss International, Statesman I, 2000-L/d capacity) located on-site. The mixing tanks are equipped with mixers appropriate to the size of the tank (e.g., 1/3 hp for the 1000-L tank). Chemical feed pumps (e.g., Blue-White Industries) will feed the concentrated solutions into the dilution lines where they pass under the control box. An electrical interlock permits the pumps to operate only when dilutions are taking place.

\subsection{Dilution System}

The dilution system was designed to accommodate a peak dilution flow rate of $8.56 \mathrm{~m}^{3} / \mathrm{h}$ (143 L/min) per pond. Influent lines branch off the main saltwater line. They are metered with a paddle-type flow sensor (Signet MK 515-P0, with MK 575 indicator/ totalizer), receive concentrated nutrients, and pass through throttling and automatic shutoff valves before discharging into the growth ponds. The piping was laid out so that fresh water could easily be tied into the dilution system if required. Effluents are pumped (Little Giant 8-CBA) through a throttling valve, are metered with a magnetic flowmeter (Signet MK565A, with MK575 indicator/totalizer), and then are passed into two harvest lines that run to the waste pond. The harvest lines can also be used for inter-pond transfer or for filling either growth pond from the inoculum pond. Influent and effluent flow rates will be matched manually with the diaphragm throttling valves, allowing for the average evaporation. A level sensor in the pond will shut off the influent flow as necessary to compensate for mismatched flows or rainy days. During the fall of 1988 and winter of 1989 , the large-scale system was operated manually in a batch mode.

\subsection{Carbonation System}

The internal sumps were constructed to allow carbonation by counterflow injection of $\mathrm{CO}_{2}$. The $0.91-\mathrm{m}$ deep $\times 0.62-\mathrm{m}$ wide sumps have vertical walls and span the full width of the channel opposite the mixing station. A vertical baffle placed in the sump obstructs the flow, forcing it down one side, around the bottom, then up and out the

other side. A $6.5-\mathrm{cm}$ radius was formed into all corners to reduce flow losses. $\mathrm{CO}_{2}$ is sparged into the downflowing stream using porous polyethylene diffusers. By matching the downflow velocity with the average bubble rise velocity, long contact times are achieved, resulting in high $\mathrm{CO}_{2}$ absorption efficiencies. The downflow velocity is controlled by both mixing speed and the relative position of the movable divider baffle. The bubble rise velocity (actually the velocity distribution) is a function of bubble size, which depends on sparger design, $\mathrm{CO}_{2}$ flow rate, salinity, and other factors. Counterflow carbonation creates hydraulic losses as a result of turbulence induced by the changes in flow direction and the "lift" associated with the rising $\mathrm{CO}_{2}$. The latter effect is negligible because the volumetric ratio of water $/ \mathrm{CO}_{2}$ is high $($ at $20 \mathrm{~cm} / \mathrm{s}$ nominal mixing velocity and $3 \mathrm{~g} / \mathrm{m}^{2} / \mathrm{h}$ algae productivity, flow rate of water $(\mathrm{Qw})=0.28 \mathrm{~m} / \mathrm{s}$, flow rate of $\mathrm{CO}_{2}$ $\left.\left(\mathrm{QCO}_{2}\right)=0.00076 \mathrm{~m}^{3} / \mathrm{s}\right)$. However, it is likely that higher sparging rates will be tested to simulate conditions in larger ponds. Losses due to turbulence are difficult to estimate but are unlikely to exceed two velocity heads $(1.3 \mathrm{~cm})$.

The $\mathrm{CO}_{2}$ is added on demand via a solenoid activated by the $\mathrm{pH}$ controller (Cole-Parmer J5654-34). Instantaneous and integrated $\mathrm{CO}_{2}$ flow is measured by positive displacement flowmeters and mass flow controllers. 


\subsection{LARGE-SCALE SYSTEM ENGINEERING ANALYSIS}

\subsection{Introduction}

The large-scale system was designed as a research vehicle intermediate in scale between the small fiberglass $\left(3-\mathrm{m}^{2}\right)$ raceways and a larger 0.5 -ha demonstration raceway. Biological and engineering scaleup problems are uncovered, and solutions elucidated, using these 0.1-ha raceways. To begin this process, an engineering analysis was performed on the system. The goals were to evaluate performance of construction techniques, hydraulic operation, and carbonation systems in terms of design expectations and future scaleup.

\subsection{Grading and Pond Depth}

The grade was designed with a 0.0006 slope from east to west, resulting in a $4.5-\mathrm{cm}$ depth differential from one end of each channel to the other. This design was implemented for ease of construction (of this relatively small system) and as an aid in draining and cleaning the ponds. The $180^{\circ}$ bends were banked and were more shallow towards the walls. This design was used to minimize cross-channel secondary flows.

Depth profiles for the two 0.1-ha raceways are shown in Figures 3-1 through 3-3. Generally, the design intent would have been accomplished, except that the soil structure at the site was poor. Earth compacting was extremely limited; the spongy clay soils did not fully compact. Instead, certain areas compacted and sank subsequent to the grading efforts. The salient result is evident in the figures: the depth profile undulates. This has had two deleterious consequences. First, the ponds are not easy to drain and clean. Second, the contractions and expansions of flow, due to the depth changes, complicate the hydraulics in the ponds and lead to an increased problem of in-pond deposition of particulates. A decision will be made later whether to correct the problem in the lined pond by using sand to even the grade.

Table 3-1 gives the deviations in channel depths for average depths of 13.5 and $13.7 \mathrm{~cm}$. The depth of operation during 1988 was about $14 \mathrm{~cm}$. Greater depths were used beginning in the spring of 1989 to reduce the magnitude of depth changes along the lengths of the channels.

\subsection{Visual Observations of Flow}

The raceways were first operated without flow deflectors around the $180^{\circ}$ bends. As expected, the flow was characterized by large eddies formed just after the bends and continuing far into each channel. The most serious problem, however, was that the flow was not straight entering the paddle wheel: water depth varied across the channel just upstream of the mixer. This condition led to flow across the paddle wheel blades, and to cross flows just after the mixer. In addition, the flow was characterized by separate concentric "tracks" traveling at various speeds around the pond. The track closest to the center wall moved the fastest, and the head differential across the mixer (upstream to downstream) formed a gradient that was greatest next to the center wall. The installation of two flow deflectors at each bend greatly straightened and evened the flow. This, in turn, reduced the areas of stagnation in each channel. It also caused the stream to flow into and off of the paddle wheel more evenly. With a straight flow at the head of each channel, fewer dead zones and cross flows occurred. In general, velocities were more uniform. 

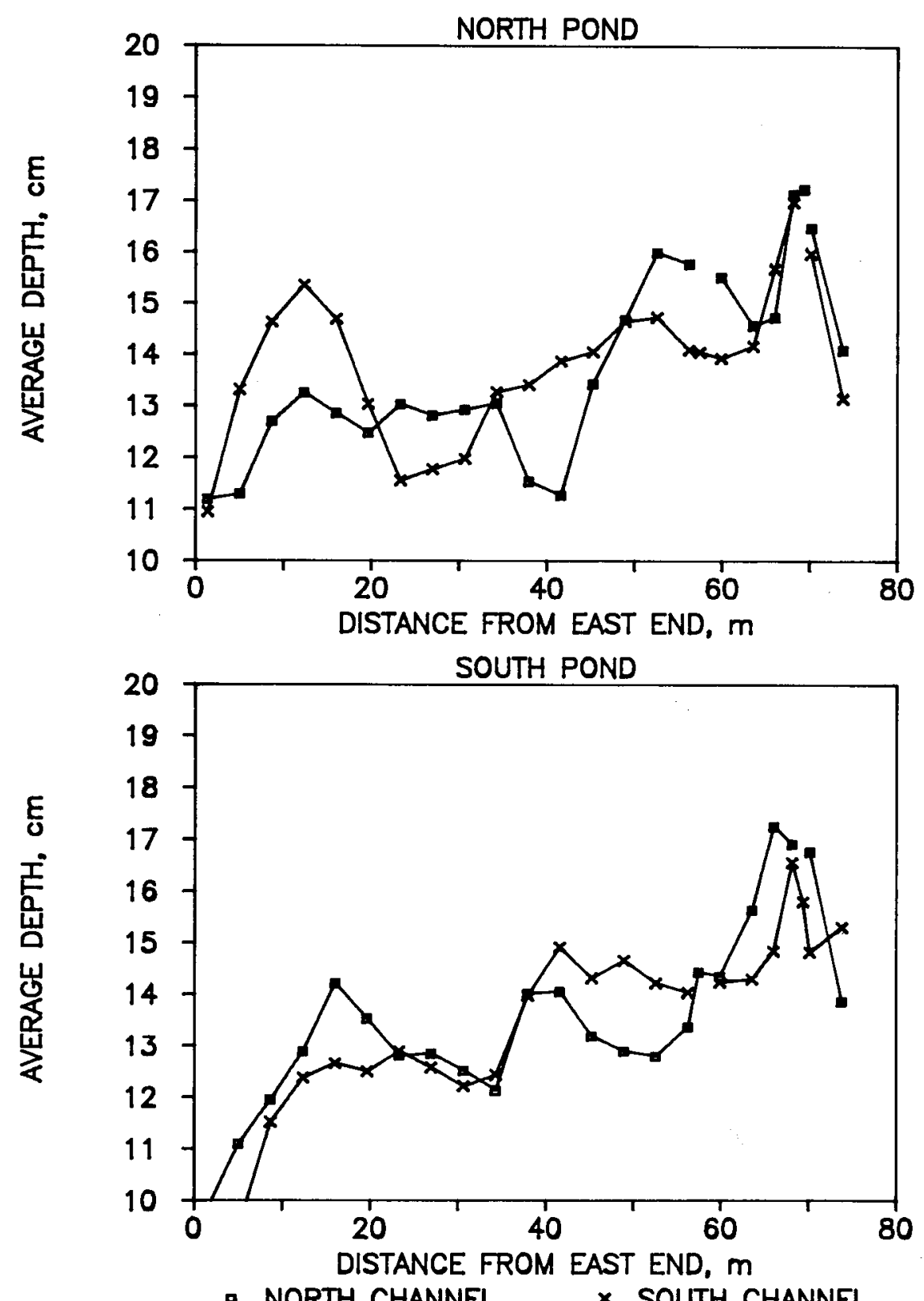

Figure 3-1. Depth profiles along channel bottoms for average pond depths of $13.7 \mathrm{~cm}$ in Nor th (lined) pond and $13.5 \mathrm{~cm}$ in South (unlined) pond 

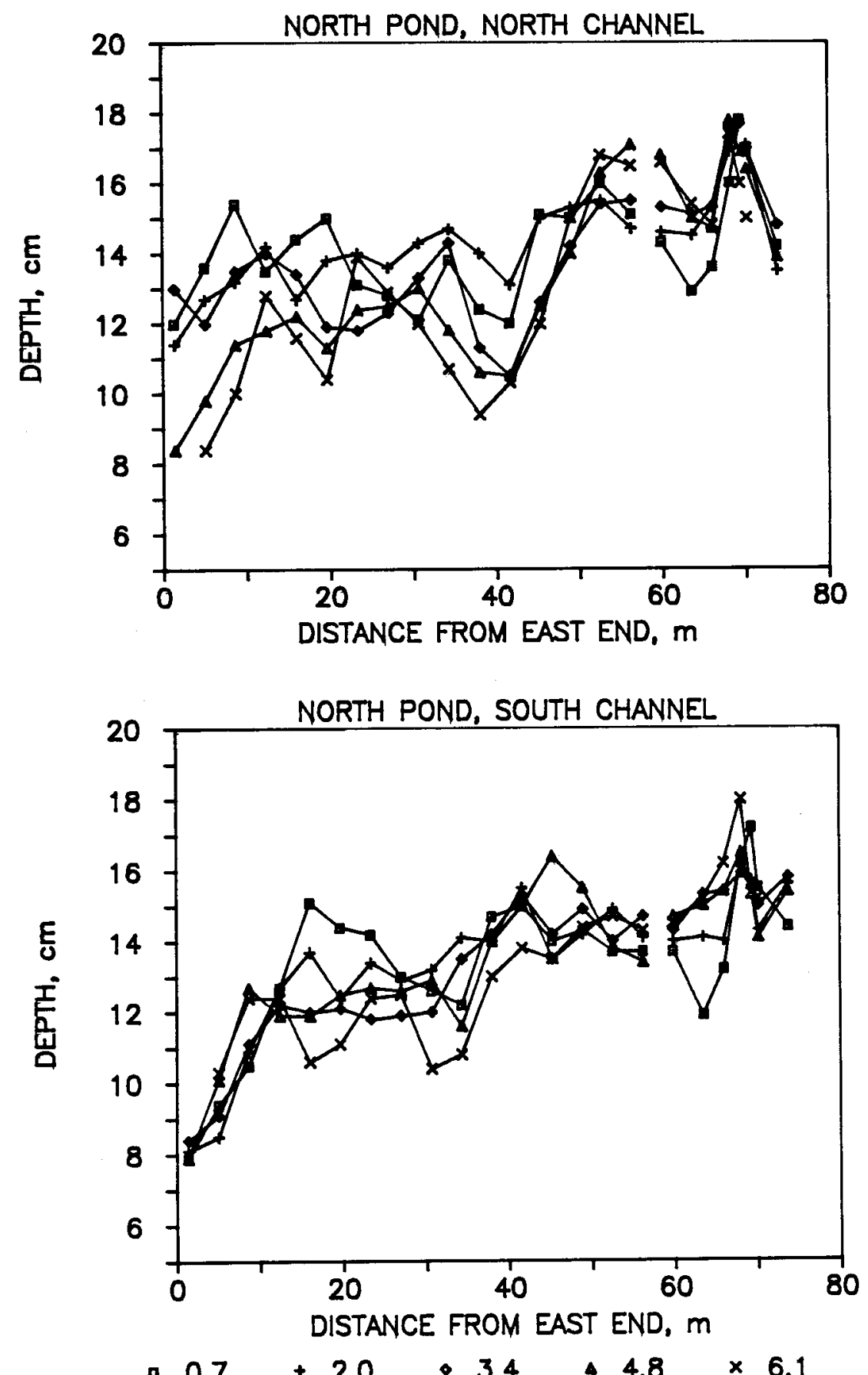

Figure 3-2. Depth profiles along channel bottoms for North (lined) pond (average depth of $13.7 \mathrm{~cm}$ ) at five locations across channel

Symbols indicate distances of measuring points from center wall 

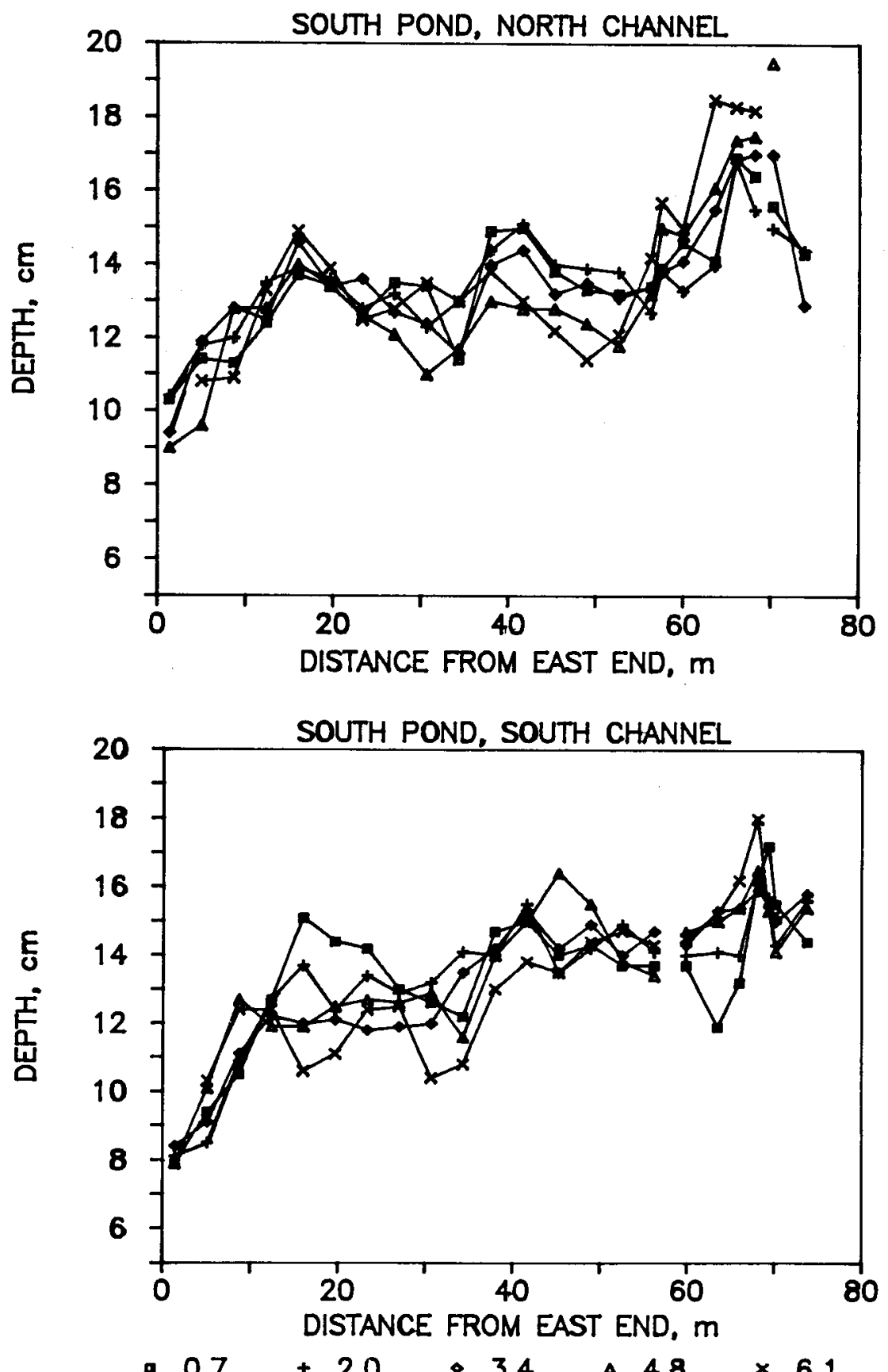

Figure 3-3. Depth profiles along channel bottoms for South (unlined) pond (average depth of $13.5 \mathrm{~cm}$ ) at five locations across channel

Symbols indicate distances of measuring points from center wall 
Table 3-1. 0.1-ha Pond Depths and Deviations (All depths in $\mathrm{cm}$ )

\begin{tabular}{|c|c|c|c|c|c|c|}
\hline & \multicolumn{3}{|c|}{ North Pond } & \multicolumn{3}{|c|}{ South Pond } \\
\hline & $\mathrm{NC}^{*}$ & $\mathrm{SC}^{*} *$ & Overall & $\mathrm{NC}^{*}$ & $\mathrm{SC}^{* *}$ & Overall \\
\hline Average depth & 13.6 & 13.8 & 13.7 & 13.6 & 13.3 & 13.5 \\
\hline Standard deviation & 2.1 & 1.8 & -- & 1.9 & 2.0 & -- \\
\hline
\end{tabular}

*NC $=$ north channel

$* * \mathrm{SC}=$ south channel

$n>100$ for each channel

Variations in velocities were visually apparent in the ponds because of the variations in water depth. These may be alleviated somewhat by operating at greater depth. As mentioned earlier, we may need to improve the evenness of the grade. This will be possible if the settling of the ponds stabilizes.

\subsection{Velocity Profiles}

Velocity profiles in open channel flow have been fit to various curves, but a simple logarithmic relationship is of ten satisfactory (Daugherty and Franzini, 1977). The data from the velocity-depth profiles were fit to the relationship: $A+B \log (y / d)$, where $A$ and $B$ are constants, $d$ is the depth, and $y$ is the distance from the bottom to the measuring point. This fit breaks down at $y=0$ (the velocity profile near the bottom changes shape as it approaches zero at the pond bottom) and usually again at $y=d$ (the surface velocity may even be lower than beneath the surface). For the measurements taken here, the functional form given here was adequate. Virtually all of the correlation coefficients were higher than 0.95 and most were higher than 0.98. It has the advantage of allowing easy calculation of the depth-averaged velocity from the fitted curve. The average velocity is equal to $B-A$, or the velocity at $y / d=0.368$. This fit also allows for an easy estimate of the corrections to the kinetic energy of the flow. If the velocity were uniform with depth, the kinetic energy could be represented by a single velocity head term. For non-uniform velocities, this term is multiplied by a correction factor, which was calculated from the log curve and determined to be 1.05 .

Velocity profiles were taken $1.4 \mathrm{~m}$ upstream from the sump in each pond at six measurement stations in each channel: $0.60,1.83,3.05,4.27,5.49$, and $6.10 \mathrm{~m}$ from the center wall. Thus the width of a given channel was divided into seven sections, each bounded by two measurement stations. After the average velocity was calculated at each of the stations (from the depth profiles), the section averages were calculated by averaging the two (depth-averaged) velocities that bounded each section. Then each section was assigned a weight, determined by the section length divided by the channel width. The average velocity of the channel was calculated as a weighted average of the section averages. Using the average depth and average velocity, an average flow rate was calculated for each section. These, in turn, were used to determine an overall average flow rate. Given the average depth of any reach of channel and the average flow rate, the velocity of flow in that reach could now be estimated. These calculations were done for several paddle wheel rotation speeds, and used in relationships between head loss and velocity (or flow rate). 
The velocity profiles obtained at four paddle wheel rotation speeds are shown in Figures 3-4 through 3-8. Average values of velocity $1.4 \mathrm{~m}$ upstream from the sump (in the return flow channel), average depths, and flow rates for the North (lined) and South (unlined) raceways are given in Table 3-2. Overall average velocities for both ponds, based on flow rate and average pond depth, are shown in Table 3-3.

The mixing system was designed to allow variation in mixing velocity from 15 to $40 \mathrm{~cm} / \mathrm{s}$. The top speed could not be reached because of mixer inefficiency at the high lifts engendered (see Section 3.5).

\subsection{Head Losses}

Depth of flow was measured across the channel at six locations in each pond at a series of paddle wheel rotation speeds. Using the still water level as a datum, the potential energy of the water was estimated at each measuring station from the difference between the measured depth of the moving water and that of the still water. If flow were steady and uniform, these measurements would be enough to determine total head losses, since flow velocities would be equal (that is kinetic energy associated with the flow would be constant). We know, however, from the depth profile, that even under steady flow conditions attained, the flow was not uniform. In one channel of each pond, the slope of the pond bottom was adverse (increasing in the direction of flow); there were depth constrictions and expansions, and there were nonuniformities associated with bends and the lift stations. Thus, some estimate had to be made of the velocity head at each location to approximate total head. Once this estimate was completed, differences in total head between locations could be estimated.

Measurements taken before and after the paddle wheel were used to indicate total losses in mixing the pond. When multiplied by water density and flow rate, these losses gave an estimate of hydraulic power requirements for mixing. Measurements taken before and after each bend were used to estimate bend losses. Measurements were also taken before and after the carbonation sumps (to determine their contribution to losses) and at the beginning and end of the channels in each pond (to isolate the "open channel flow" losses). Estimates of the head loss for each pond section are given in Table 3-4.

Each of these measurements contained a considerable level of approximation. An error of $0.05-0.1 \mathrm{~cm}$ was associated with each depth measurement at the lower mixing speeds, and an error of twice this at the higher speeds (despite the use of stilling wells). Since two subtractions were needed to obtain a head difference, the minimum measurement error for potential head loss was 0.1 to $0.2 \mathrm{~cm}$. The errors in estimating velocity head were composed of the individual velocity measurement errors (about $10 \%$ of the mean at low velocity and $3 \%$ at high velocity), the errors in determining average velocity over pond depth and channel width (about 10\%), the propagation errors in the translation of velocity from the velocity-measuring station to the head-measuring station (using the equation of continuity for flow rate), the underestimate of the correction to kinetic head deriving from highly nonuniform velocity distributions (especially near bends, sumps, and around the paddle wheel), and the propagation errors in subtracting to get velocity head differences. At low mixing speeds, the velocity head differences were insignificant compared to the potential head differences. Thus, errors in measuring depths, and error propagation led to about a $0.2-\mathrm{cm}$ limit to precision. At high mixing speeds, the velocity head differences were $5 \%$ to $30 \%$ of the potential head differences. Thus, both sources of error were important in the overall observed error of $20 \%$ of the mean. The accuracy of the measurements was also limited. Accuracy errors were introduced when averaging the head differences across the channel. Four discrete measuring points were used. Velocity was only measured in the direction along the channel. Alihough lhe flow was 

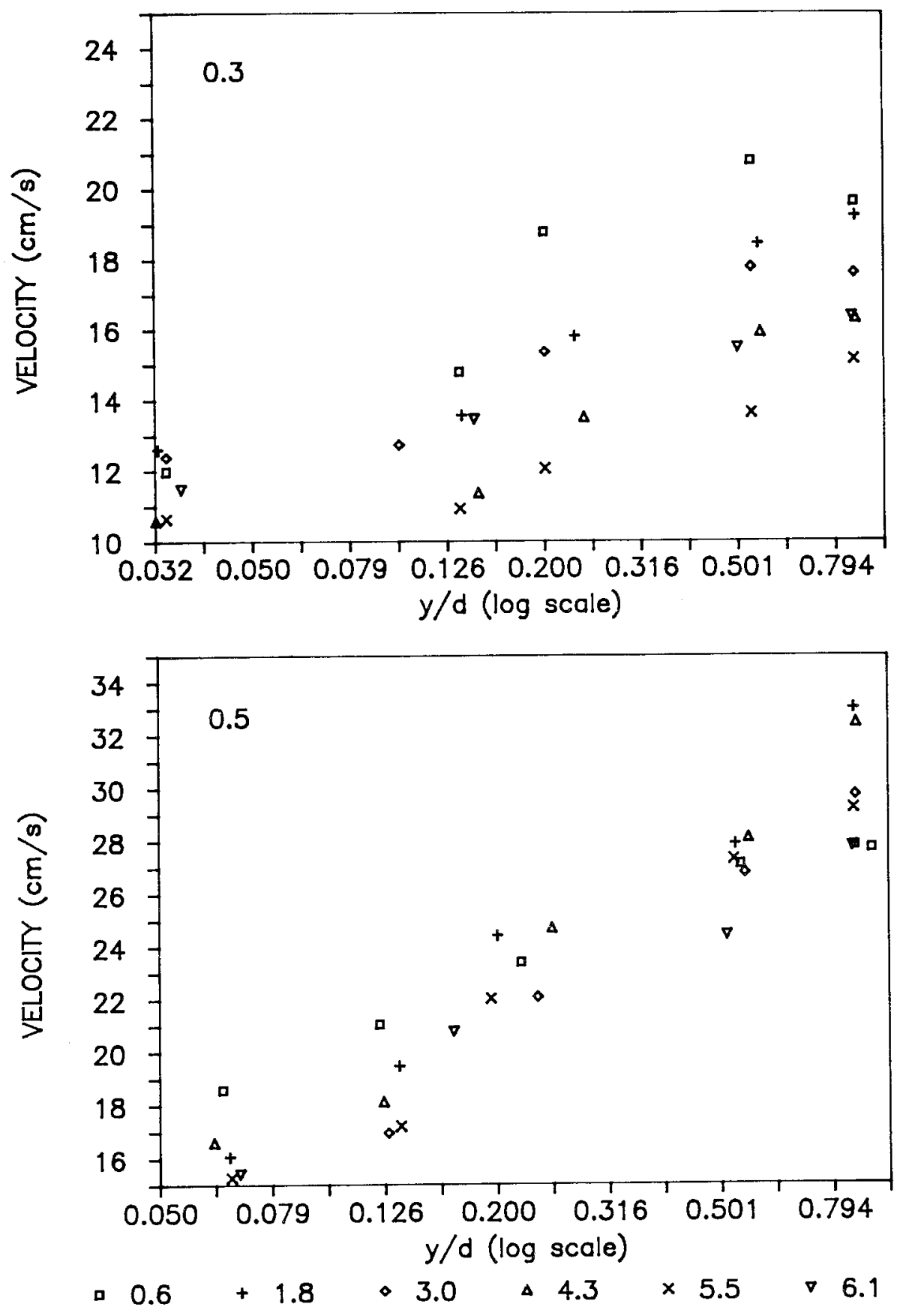

Figure 3-4. Velocity-depth profiles in North (lined) pond at paddle wheel rotation settings of $0.3(2.7 \mathrm{rpm})$ and $0.5(4.4 \mathrm{rpm})$

Symbols indicate distances of measuring station from center wall 

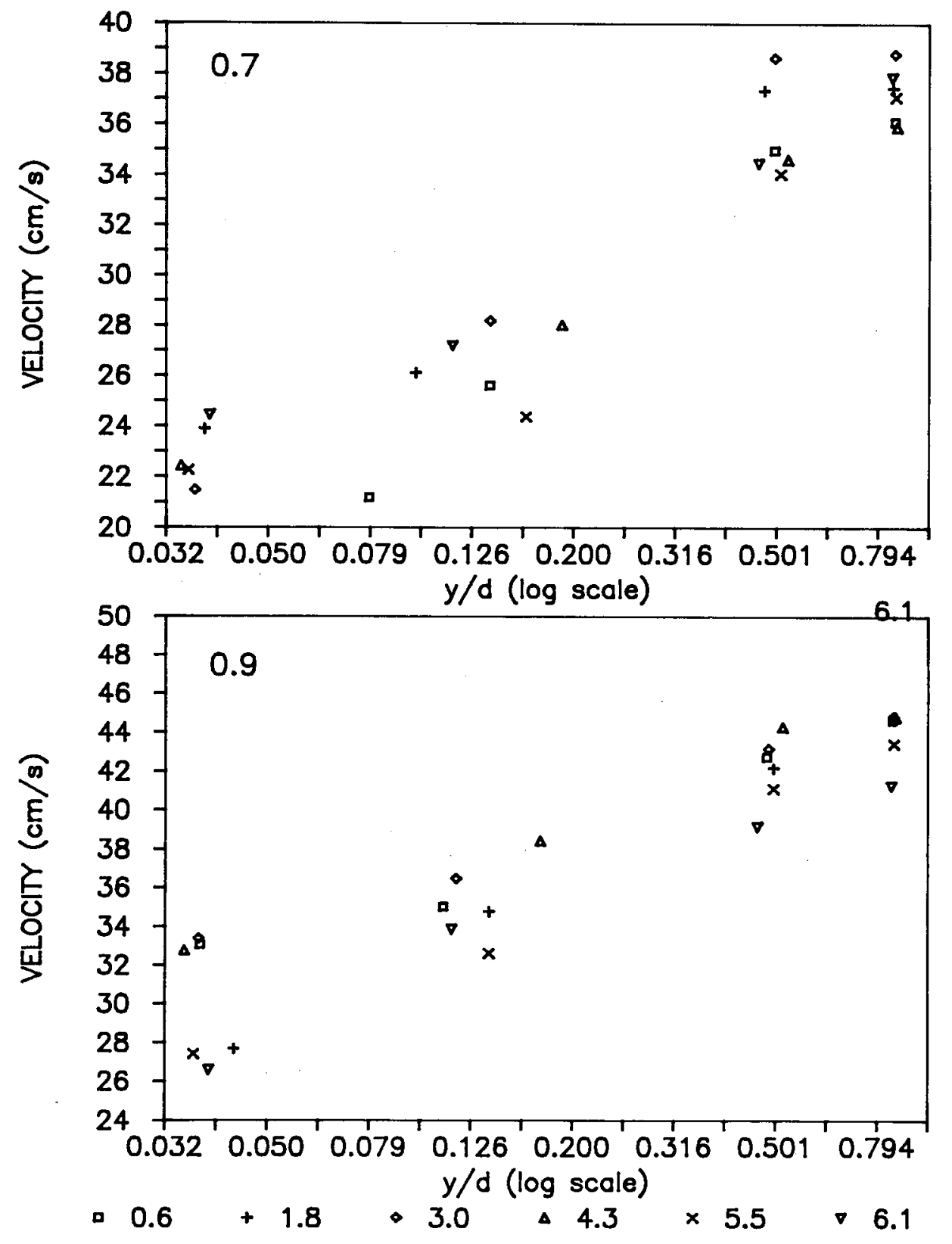

Figure 3-5. Velocity-depth profiles in North (lined) pond at paddle wheel rotation settings of $0.7(6.1 \mathrm{rpm})$ and $0.9(7.8 \mathrm{rpm})$

Symbols indicate distances of measuring station from center wall 

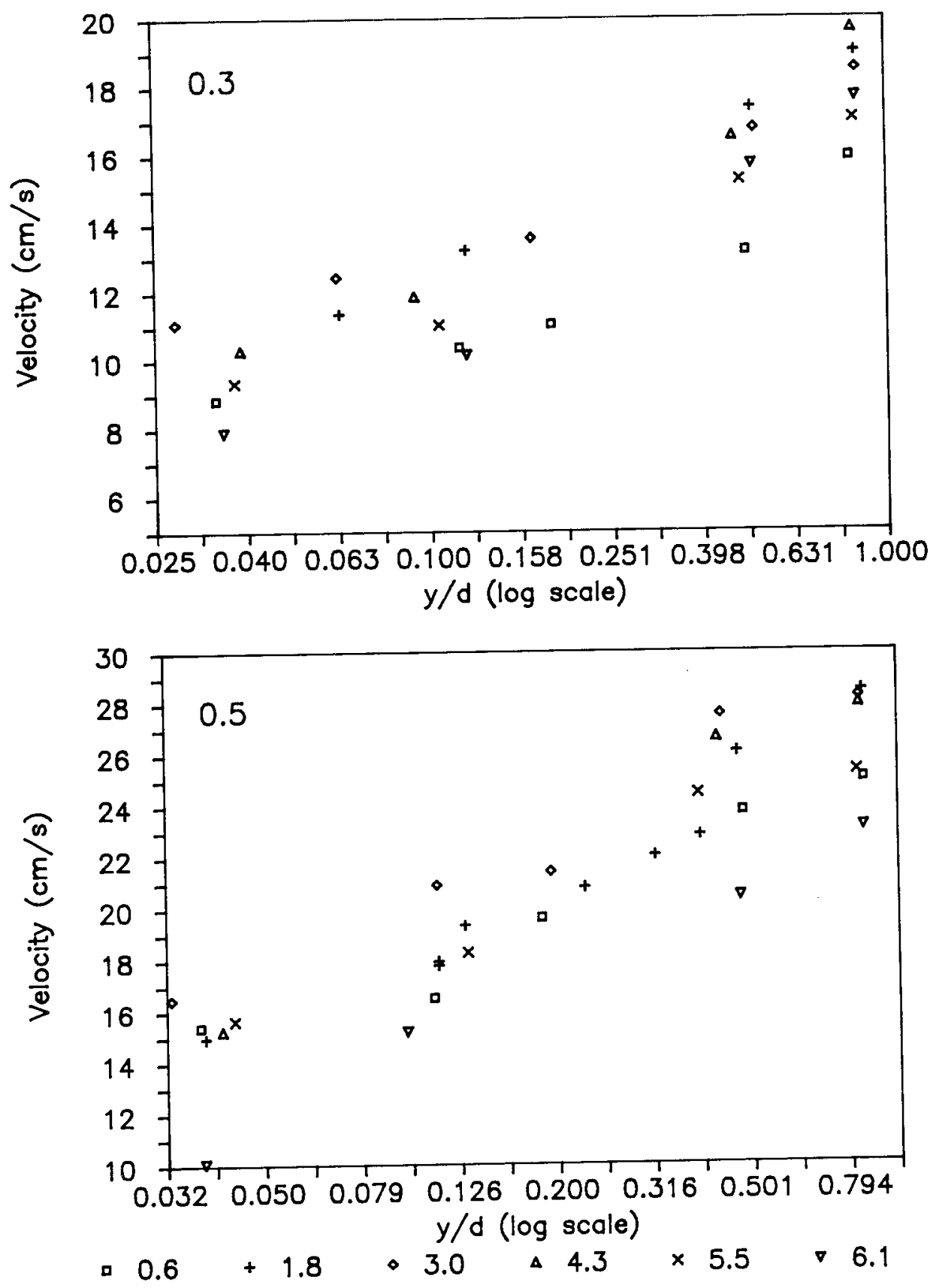

Figure 3-6. Velocity-depth profiles in South (unlined) pond at paddle wheel rotation settings of $0.3(2.7 \mathrm{rpm})$ and $0.5(4.4 \mathrm{rpm})$

Symbols indicate distances of measuring station from center wall 

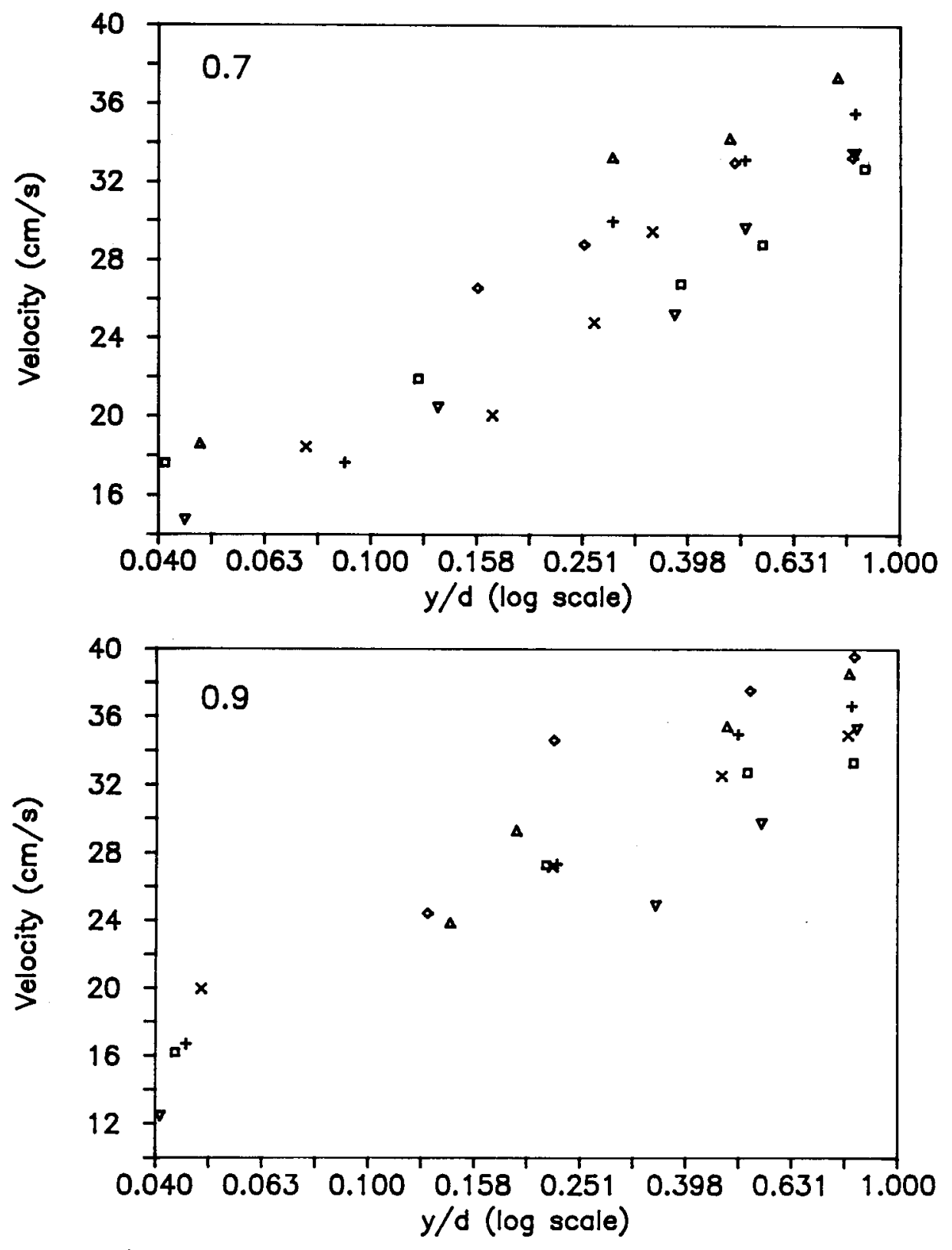

- $0.6+1.8$ - $3.0 \quad 4.3 \quad \times \quad 5.5 \quad \nabla 6.1$

Figure 3-7. Velocity-depth profiles in South (unlined) pond at paddle wheel rotation settings of $0.7(6.1 \mathrm{rpm})$ and $0.9(7.8 \mathrm{rpm})$

Symbols indicate distances of measuring station from center wall 

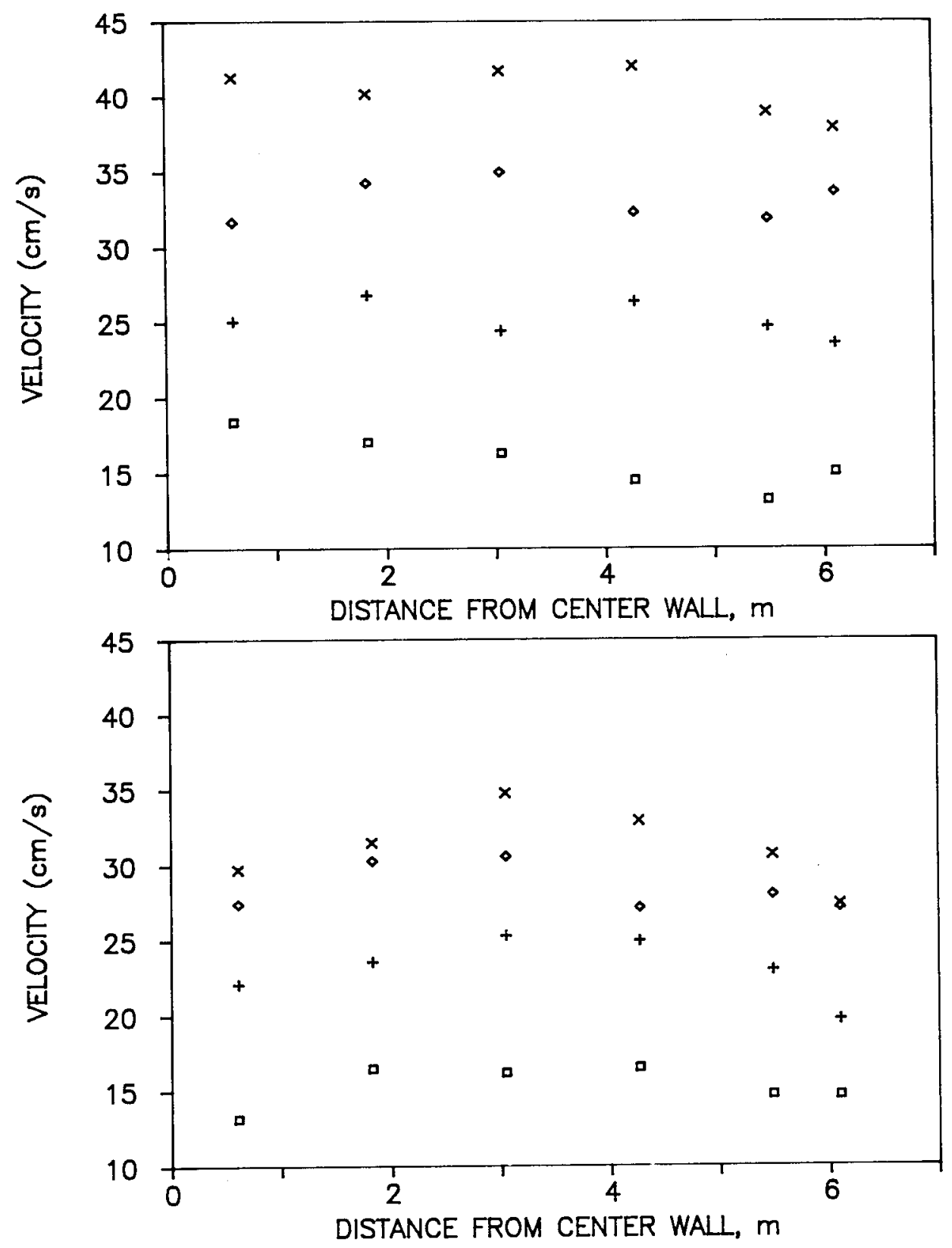

Figure 3-8. Profiles of depth-averaged velocity across the return channel (1.4-m upstream from sump) in each 0.1-ha raceway

Symbols indicate paddle wheel rpm: boxes, 2.7; pluses, 4.4; diamonds, 6.1 ; crosses, 7.8 . 
Table 3-2. Average Depths, Velocities, and Flow Rates 1.4-m Upstream from Sumps in 0.1-ha Raceways

\begin{tabular}{|c|c|c|c|c|c|c|}
\hline \multirow{2}{*}{$\begin{array}{l}\text { Padd le Whee I } \\
\text { Rotation } \\
\text { (rpm) }\end{array}$} & \multicolumn{3}{|c|}{ North Pond } & \multicolumn{3}{|c|}{ South Pond } \\
\hline & $\begin{array}{c}\mathrm{d} \\
(\mathrm{cm})\end{array}$ & $\begin{array}{c}\mathrm{V} \\
(\mathrm{cm} / \mathrm{s})\end{array}$ & $\begin{array}{c}Q \\
(L / s)\end{array}$ & $\underset{(\mathrm{cm})}{d}$ & $\begin{array}{c}\mathrm{V} \\
(\mathrm{cm} / \mathrm{s})\end{array}$ & $\begin{array}{c}\mathrm{Q} \\
(\mathrm{L} / \mathrm{s})\end{array}$ \\
\hline $\begin{array}{l}2.7 \\
4.4 \\
6.1 \\
7.8\end{array}$ & $\begin{array}{l}15.1 \\
15.3 \\
13.9 \\
13.7\end{array}$ & $\begin{array}{l}15.6 \\
24.9 \\
32.5 \\
39.7\end{array}$ & $\begin{array}{l}157 \\
260 \\
310 \\
371\end{array}$ & $\begin{array}{l}14.0 \\
12.7 \\
11.1 \\
11.2\end{array}$ & $\begin{array}{l}15.1 \\
22.7 \\
28.0 \\
30.7\end{array}$ & $\begin{array}{l}146 \\
197 \\
213 \\
235\end{array}$ \\
\hline
\end{tabular}

Note: Average pond depths were 13.7 and $13.5 \mathrm{~cm}$ for North and South ponds, respectively, when measurements were taken.

Table 3-3. Average Velocities in 0.1-ha Raceways $(\mathrm{cm} / \mathrm{s})$

\begin{tabular}{lrrrrrr}
\hline & \multicolumn{5}{c}{ Paddle Wheel Rotation Speed (rpm) } \\
\cline { 2 - 7 } & 2.7 & $3.6^{*}$ & 4.4 & $5.3^{*}$ & 6.1 & 7.8 \\
\hline North pond & 16.7 & 24.4 & 27.6 & 30.8 & 33.0 & 39.5 \\
South pond & 15.8 & 17.1 & 21.3 & 22.1 & 23.0 & 25.0 \\
\hline
\end{tabular}

* Velocity determined from interpolated flow rate.

Note: Velocities were calculated from measured flow rate and average depth of $13.7 \mathrm{~cm}$ for North pond and $13.5 \mathrm{~cm}$ for South pond.

predominantly in this direction, large eddies, cross flows, and vertical flows all contributed to the kinetic energy of the flow, but were not included in the measurements. At the higher mixing speeds, the effects of wave action were averaged when head and velocity were estimated. Their contribution to the energy of flow may have been greater than the average used.

From the nonlinearity in the curve of velocity versus paddle wheel rotation speed (Table 3-3), the mixer in the unlined (South) pond appears to have become more inefficient at higher rpm. The frictional losses were so great during circulation around the pond at high flow rate that the draw down to the paddle wheel intake became very great. Thus the amount of water lifted by each blade of the paddle wheel was suboptimal. In addition, the paddle wheel was not able to convert the increased water velocity on the intake side into potential energy on the output side. Thus the large velocity head, due to the draw down, was dissipated. These problems may be alleviated by operating the ponds at greater depth. As mentioned earlier, this will be done to minimize depth variation (as a fraction of average depth) at all mixing velocities. The paddle wheel intake could also be designed differently; but we do not anticipate that the ponds will be operated at high paddle wheel rotation speeds. 
Table 3-4. Total Head Loss $(\mathrm{cm})$ for Each Section of 0.1-ha Raceways

\begin{tabular}{|c|c|c|c|c|c|c|}
\hline & \multicolumn{6}{|c|}{ Paddle Wheel Rotation Speed (rpm) } \\
\hline & 2.7 & 3.6 & 4.4 & 5.3 & 6.1 & 7.8 \\
\hline \multicolumn{7}{|l|}{ North pond } \\
\hline First channel & $\begin{array}{l}0.33 \\
(20)\end{array}$ & $\begin{array}{l}0.53 \\
(19)\end{array}$ & $\begin{array}{l}0.60 \\
(15)\end{array}$ & $\begin{array}{l}0.66 \\
(13)\end{array}$ & $\begin{array}{l}0.61 \\
(9)\end{array}$ & $\begin{array}{l}0.64 \\
(10)\end{array}$ \\
\hline Second channel & $\begin{array}{l}0.19 \\
(11)\end{array}$ & $\begin{array}{l}0.43 \\
(15)\end{array}$ & $\begin{array}{l}0.68 \\
(17)\end{array}$ & $\begin{array}{l}0.97 \\
(19)\end{array}$ & $\begin{array}{l}1.20 \\
(19)\end{array}$ & $\begin{array}{l}1.53 \\
(24)\end{array}$ \\
\hline First bend & $\begin{array}{l}0.40 \\
(24)\end{array}$ & $\begin{array}{l}0.57 \\
(20)\end{array}$ & $\begin{array}{l}0.82 \\
(21)\end{array}$ & $\begin{array}{l}0.92 \\
(18)\end{array}$ & $\begin{array}{l}1.17 \\
(18)\end{array}$ & $\begin{array}{l}1.17 \\
(19)\end{array}$ \\
\hline Second bend & $\begin{array}{l}0.34 \\
(20)\end{array}$ & $\begin{array}{l}0.74 \\
(26)\end{array}$ & $\begin{array}{l}1.15 \\
(29)\end{array}$ & $\begin{array}{l}1.59 \\
(31)\end{array}$ & $\begin{array}{l}2.32 \\
(36)\end{array}$ & $\begin{array}{l}1.65 \\
(26)\end{array}$ \\
\hline Carbonation sump & $\begin{array}{l}0.41 \\
(25)\end{array}$ & $\begin{array}{l}0.58 \\
(20)\end{array}$ & $\begin{array}{l}0.67 \\
(17)\end{array}$ & $\begin{array}{l}0.97 \\
(19)\end{array}$ & $\begin{array}{l}1.09 \\
(17)\end{array}$ & $\begin{array}{l}1.30 \\
(21)\end{array}$ \\
\hline Total & 1.66 & 2.85 & 3.91 & 5.12 & 6.39 & 6.30 \\
\hline \multicolumn{7}{|l|}{ South pond } \\
\hline First channel & $\begin{array}{l}0.40 \\
(14)\end{array}$ & $\begin{array}{l}0.60 \\
(13)\end{array}$ & $\begin{array}{l}0.82 \\
(13)\end{array}$ & $\begin{array}{l}0.99 \\
(12)\end{array}$ & $\begin{array}{l}0.98 \\
(10)\end{array}$ & -- \\
\hline Second channel & $\begin{array}{l}0.78 \\
(27)\end{array}$ & $\begin{array}{l}1.24 \\
(26)\end{array}$ & $\begin{array}{l}1.97 \\
(30)\end{array}$ & $\begin{array}{l}2.30 \\
(27)\end{array}$ & $\begin{array}{l}2.74 \\
(27)\end{array}$ & -- \\
\hline First bend & $\begin{array}{l}0.80 \\
(27)\end{array}$ & $\begin{array}{l}1.42 \\
(30)\end{array}$ & $\begin{array}{l}1.69 \\
(26)\end{array}$ & $\begin{array}{l}2.12 \\
(25)\end{array}$ & $\begin{array}{l}2.23 \\
(22)\end{array}$ & - \\
\hline Second bend & $\begin{array}{l}0.49 \\
(17)\end{array}$ & $\begin{array}{l}0.99 \\
(21)\end{array}$ & $\begin{array}{l}1.51 \\
(23)\end{array}$ & $\begin{array}{l}2.53 \\
(30)\end{array}$ & $\begin{array}{l}3.53 \\
(35)\end{array}$ & -- \\
\hline Carbonation sump & $\begin{array}{l}0.47 \\
(16)\end{array}$ & $\begin{array}{l}0.47 \\
(10)\end{array}$ & $\begin{array}{l}0.50 \\
(8)\end{array}$ & $\begin{array}{l}0.59 \\
(7)\end{array}$ & $\begin{array}{l}0.68 \\
(7)\end{array}$ & -- \\
\hline Total & 2.94 & 4.69 & 6.51 & 8.54 & 10.17 & - \\
\hline
\end{tabular}

Note: Numbers in ( ) are percentage of total head loss.

\subsection{Roughness Coefficients}

For design purposes, open channel flow is characterized by the Manning equation and the Manning's roughness coefficient. Although these devices are most useful for ideal channels (uniform flow), they are still guides in the estimation of head loss of large channel reaches. To derive estimates of Manning's n, we used the data from the first 
channel (outgoing flow from the paddle wheel) and second channel (return flow). In the return channels, the average grade was at least in the direction of flow. However, because of the depth variations, flow was probably never uniform. The roughness coefficients calculated are given in Table 3-5. Both the 0.010 value for the North (lined) pond and the 0.0173 for the South (unlined) pond are within the range expected.

\subsection{Mixing Power}

From the measurements of total head loss around the ponds and the flow rates, the power dissipated by the fluid motion was calculated. This is called the hydraulic power. A theoretical hydraulic power was calculated from Manning's equation, assuming that the only losses were due to the bottom roughness. The ratio gives an indication of how much of the actual hydraulic power was dissipated in bends, the sumps, and deviation from uniform flow in ideal channels. This ratio was $41 \%$ for each of the ponds. The actual power delivered to the paddle wheel shaft (the net shaft power) was estimated for the

Table 3-5. Manning's Roughness Coefficients for 0.1-ha Raceways

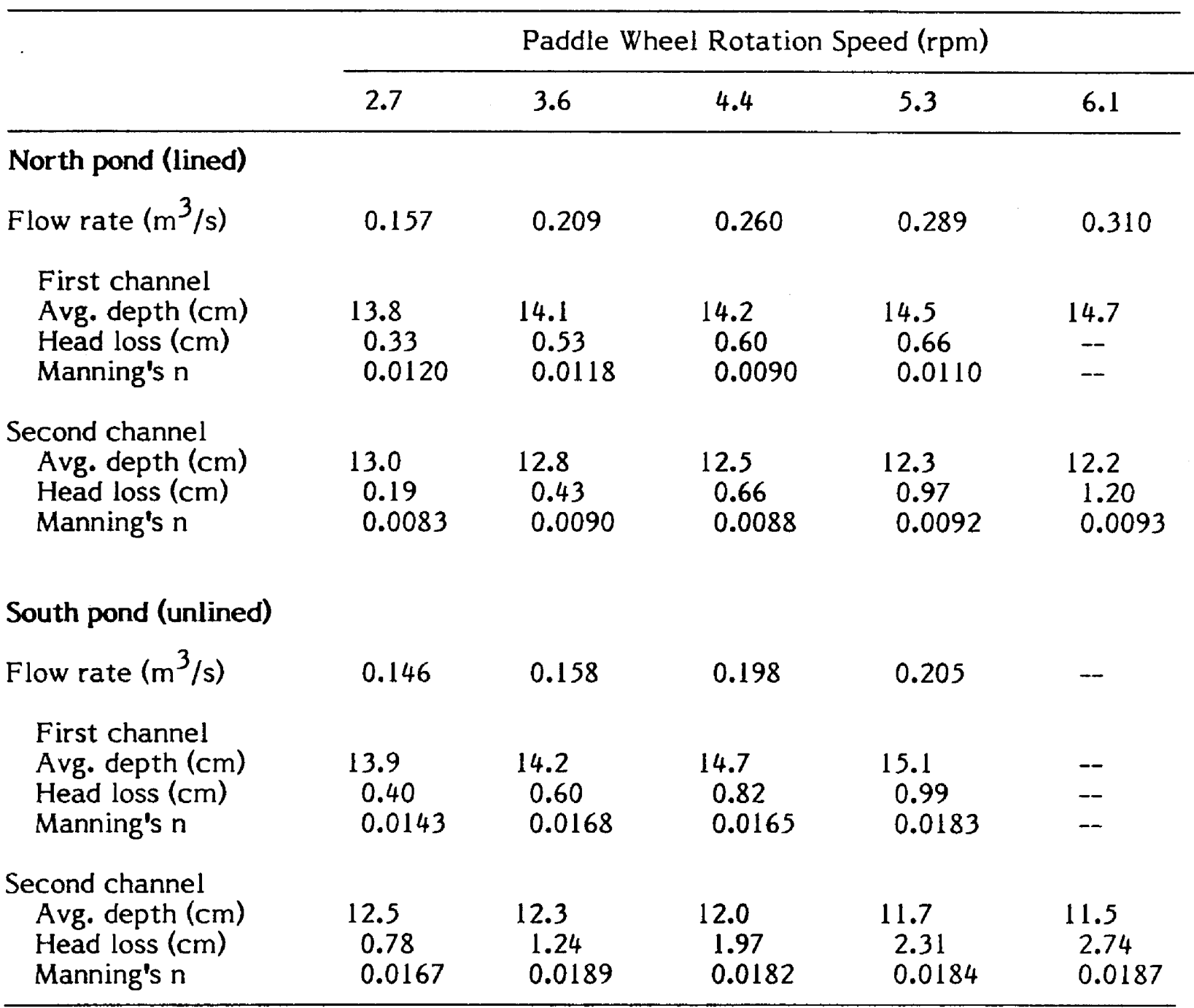


North (lined) pond. This was done, at each paddle wheel rotation speed, by taking the difference between the wattage input to the mixing drive system (motor, speed reducers, shaft) with water in the pond (load power) and without water in the pond (no-load power). The hydraulic power divided by this net shaft power is an estimate of the paddle wheel efficiency. As alluded to above, the mixer efficiency decreased with increasing mixing speed, from $76 \%$ to $40 \%$. At the two highest mixing speeds, the kinetic energy of the water entering the paddle wheel lowered the total hydraulic head loss $30 \%$ and $50 \%$, respectively. The inability of the mixer to conserve this kinetic energy resulted in the lower efficiency. Table 3-6 summarizes the power measurements taken.

A paddle wheel efficiency greater than $100 \%$ was calculated for the lowest mixing speed. The errors associated with the measured power were large at low mixing speeds. Since the system was designed to produce velocities ranging from 15 to $40 \mathrm{~cm} / \mathrm{s}$, large motors and speed reduction units were used. However, these were not very efficient at low mixing speed. A large amount of power was dissipated even under no-load conditions. The net shaft power is the difference between a loaded and non-loaded power measurement. At all mixing speeds both of these numbers were large (500-1500 W), but at low mixing speeds, the difference was small (less than $20 \mathrm{~W}$ ). The propagated error of subtraction was $15 \mathrm{~W}$, so the errors in estimates of net shaft power were large. Another error, stemming from the influence of wind on the power measurements (especially no-load measurements), is difficult to estimate. The standard deviation of replicate wattmeter readings taken one right after the other was about $0.5 \%$. However, the standard deviation of sets of replicates, taken at various temporal separations was greater, about $3 \%$. In addition to these precision errors, there was an accuracy error in the method. The no-load wattage is an estimate of the power dissipation in the drive train under load conditions, as opposed to the power delivered to the paddle wheel shaft. This power is not independent of load, so that use of the no-load measurement probably resulted in an underestimate of the drive train power and thus an underestimate of the paddle wheel efficiency. Figure 3-9 summarizes the results of the power measurements as plots against average pond velocity.

Table 3-6. Mixing Power Requirements for 0.1-ha Raceways (given in W)

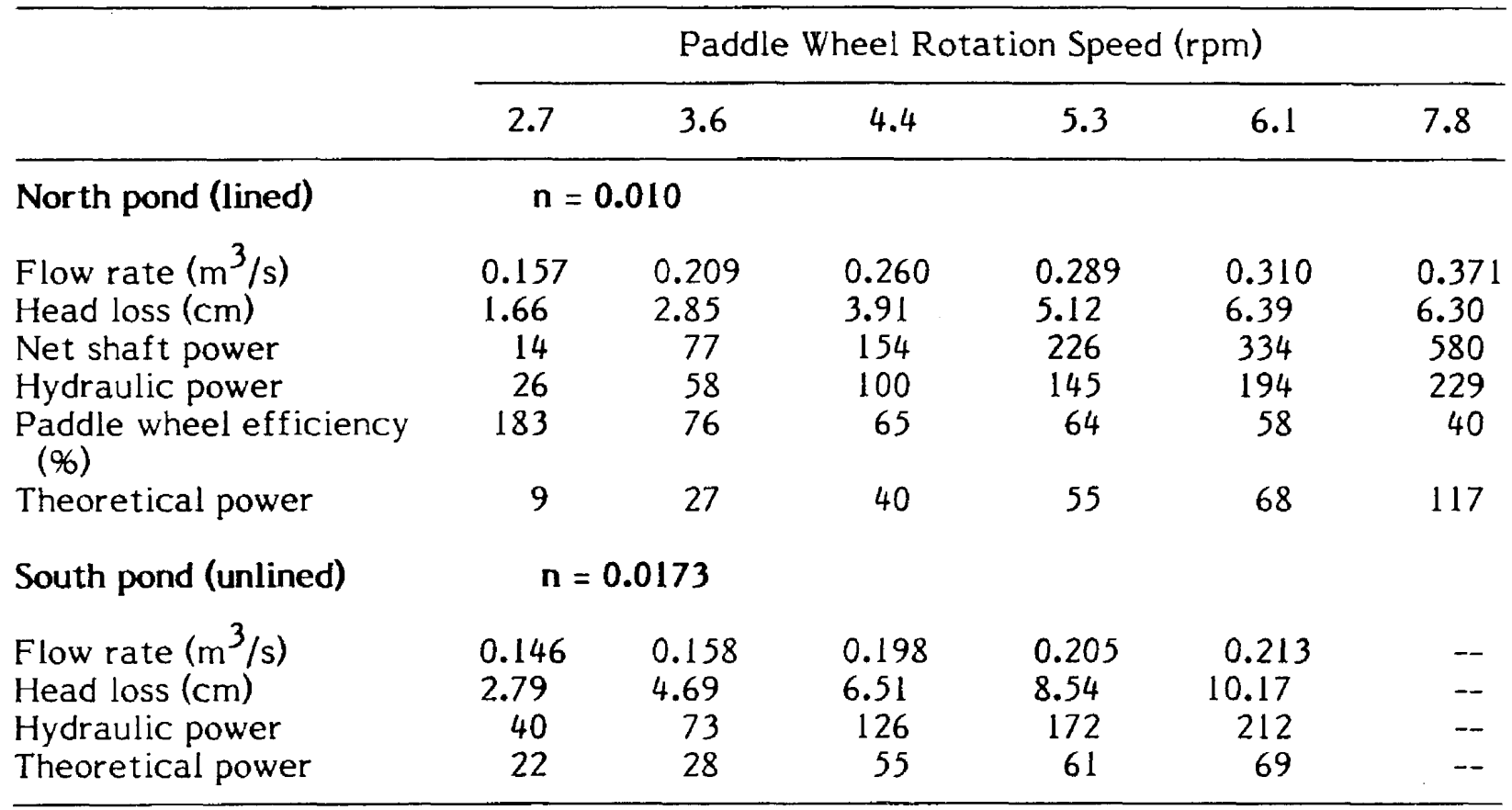




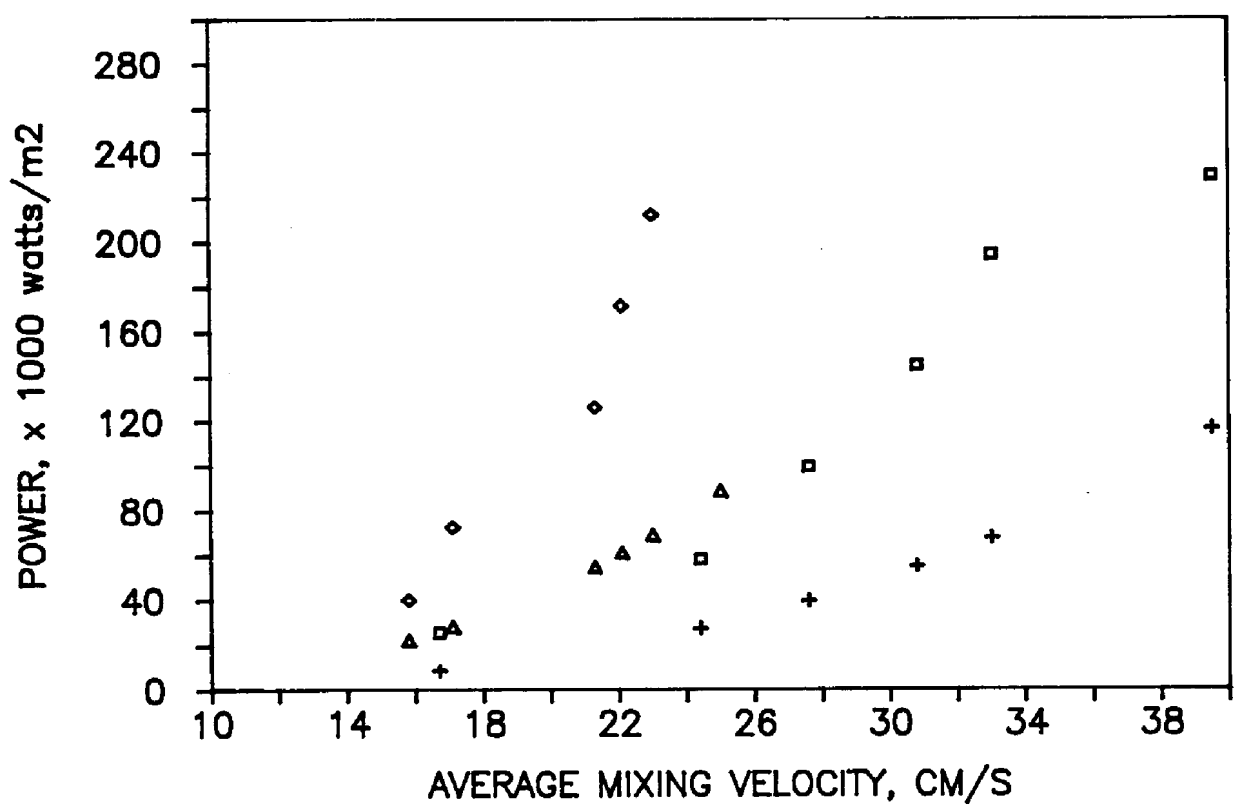

Figure 3-9. Mixing power as a function of average water velocity in 0.1 -ha raceways

Total hydraulic power consumption: North (lined) pond, boxes; South (unlined) pond, diamonds. Power consumption due only to channel roughness: North pond, pluses; South pond, triangles.

\subsection{Carbonation}

\subsubsection{Introduction}

Carbon dioxide is the single most costly input to the algal biomass fuels process (Neenan et al., 1986). The delivery and utilization of carbon in algae ponds are significant to the design and operation. Unlike other algal nutrients (e.g., nitrogen and phosphorus) which have a high solubility in water (relative to their content in algae) and can be added intermittently, carbon dioxide has a low solubility in water and must be continually replenished in an actively growing culture. One factor that aids the storage of $\mathrm{CO}_{2}$ is the carbonate buffer; however, the Roswell SaW and seawater (alkalinities of 3.6, and $2.7 \mathrm{mmol}$, respectively) can only store enough $\mathrm{CO}_{2}$ to produce approximately $1 \mathrm{~g} / \mathrm{m}^{2}$ for a $\mathrm{pH}$ rise from 7.0 to 7.5 . In summary, the amount of storage a given water type will have is dependent upon its alkalinity, carbonate equilibria, and, of course, its $\mathrm{pH}$.

The $\mathrm{CO}_{2}$ is injected into the ponds near the bottom of the sumps. The sumps contain a baffle that prevents the lateral flow of water. Instead, the flow is directed down to the sump bottom, under the baffle, up behind the baffle and out. (The predicted operation of sumps is discussed in detail in Weissman and Goebel [1987].) The efficiency depends primarily on the contact time and area between the gas and liquid phases, and is affected by the buffering capacity of the liquid. The contact area is determined primarily by the 
bubble size distribution of the gas. The contact time is determined by these factors along with the water velocity (direction and magnitude) which determine the rise velocity of bubbles relative to the water. Minimization of capital expenditures requires that the number of sumps be reduced as well as their depth. Thus, a rather large mass of gas must flow into a relatively few sumps, be efficiently absorbed, and be stored in the liquid buffer while still maintaining both the $\mathrm{pH}$ and $\mathrm{CO}_{2}$ within the range optimal for algal growth.

Unfortunately the $\mathrm{CO}_{2}$ which is injected and stored in the water's carbonate buffer can also be lost to the surrounding atmosphere as the water tries to equilibrate with air levels of $\mathrm{CO}_{2}$. The raceways' ponds are shallow reactors with an enormously large surface-area-to-volume ratio, which is essential since the limiting input--the sunlight-enters only through exposed surface area. As a consequence, $\mathrm{CO}_{2}$ can easily escape from the liquid to the atmosphere, where the concentration is low. The two factors that affect outgassing the most are the concentration in the liquid and the resistance to movement through the gas-liquid interface. Both are unfavorably affected as pond depth is decreased. The mass transfer resistance also decreases as the mixing energy input to the pond increases, since this increases the rate at which the pond surface is renewed with $\mathrm{CO}_{2}$-rich water from beneath the surface. Thus, a major undertaking of this project has been to optimize the often conflicting goals of increasing algal productivity (sufficient mixing and $\mathrm{pCO}_{2}$ ) and decreasing the opportunity for $\mathrm{CO}_{2}$ loss.

The sumps in the large-scale system were designed to be of moderate depth (about $1 \mathrm{~m}$ ), to be operated either co- or countercurrently, and to be capable of being retrofitted with a cover for catching gas and recycling it. During this subcontract period, operation was restricted to the nonrecycle, countercurrent mode to assess the injection efficiency.

\subsubsection{Materials and Methods}

All of the $\mathrm{pH}$ measurements were made with a Model 601 Orion Ionalyzer. Alkalinity was determined on $50-\mathrm{mL}$ samples with either 0.05 or $0.01 \mathrm{~N} \mathrm{HCl}$ and titrating to $\mathrm{pH} \mathrm{4.20.} \mathrm{A}$ minimum of three titrations were performed per sample.

Total inorganic carbon (TIC) was measured using an Ocean Instruments Total Organic Carbon analyzer (Model 520). This instrument works by acidifying a sample with 5\% $\mathrm{H}_{3} \mathrm{PO}_{4}$, which converts all inorganic forms of carbon to $\mathrm{CO}_{2}$. The sample is then purged with a gas stream of $\mathrm{N}_{2}$ and passed through a nondispersive infrared detector. Integrated signal response is compared against a standard for conversion to $\mathrm{mg} / \mathrm{L}$ total carbon. The instrument was blanked with $\mathrm{N}_{2}$ purged deionized-distilled water, and the carbon standard was a $100 \mathrm{mg} / \mathrm{L}$ (on a total carbon basis) solution of $\mathrm{Na}_{2} \mathrm{CO}_{3}$. Reproducibility of the standard was within 1\%, and the average percent deviation of all runs was less than $0.5 \%$.

Samples were withdrawn automatically every three minutes from a $2-\mathrm{L}$, wide mouth Erlenmeyer flask that served as an equilibrium vessel. The flask was mixed with a magnetic stir bar and sparged with a $\mathrm{CO}_{2} / \mathrm{N}_{2}$ gas mixture introduced through a coarse-fritted cylinder near the bottom of the vessel. The gas mixture was adjusted using $\mathrm{N}_{2}(2 \mathrm{slpm})$ and $\mathrm{CO}_{2}(50 \mathrm{sccm})$ flow controllers (Model FC-260, Tylan Corp.). The amounts of each gas were adjusted electronically. The gas flow was passed through a humidifier before entering the equilibrium vessel. Equilibrium was defined by no change in $\mathrm{pH}$ (.01 unit) for a period of $10 \mathrm{~min}$. 
The dissociation constants for the carbonate system were determined by regressing the pH-TIC data using the equilibrium equations as given in Table 4.2 of Stumm and Morgan (1980). The best fit was determined by a trial and error procedure until we obtained a minimum in the sum of squares. The pH-TIC data set included some previous measurements not reported in Table 3-7. These measurements had to be corrected for a difference in alkalinity, which was done by calculating $\mathrm{dTIC} / \mathrm{dAlk}$ at each $\mathrm{pH}$ value.

Injection efficiencies were measured in the carbonation sump of one of the 0.1 -ha ponds and in a $600-\mathrm{L}$ polyethylene tank. These experiments were performed by measuring the increase in total carbon in the liquid after sparging a known amount of carbon as $\mathrm{CO}_{2}$ into the vessel. Liquid phase inorganic carbon was determined by measuring the $\mathrm{pH}$ and calculating TIC using the carbonate dissociation constants determined for the RTF SaW groundwater. The $\mathrm{pH}$ measurements were taken before and after carbonation, with the "after" measurements collected following a period of hand mixing. The amount of $\mathrm{CO}_{2}$ injected was measured by a Sierra Instruments Mass Flow Controller (0-75 slpm) which also totalized the flow. The $\mathrm{CO}_{2}$ was introduced through a 2.5-cm-diameter, porous, polyethylene diffuser located in the bottom of the tank and approximately $0.25 \mathrm{~m}$ from the bottom of the carbonation sump. Two 0.3-m-long diffusers were mounted at the end of five main feedlines distributed across the width of the sump. Thus a total of $3.1 \mathrm{~m}$ of diffuser pipe was used in the carbonation sump. In the tank, only one header was used; therefore, only $0.6 \mathrm{~m}$ of diffuser was used, which was located approximately $0.05 \mathrm{~m}$ from the tank bottom.

Rates of outgassing were determined by measuring the change in $\mathrm{pH}$ per unit time in clean, noninoculated, 0.1 -ha ponds. For each condition of mixing speed and depth, the $\mathrm{pH}$ was allowed to rise at least $0.5 \mathrm{pH}$ unit--typically in the range of 7.0 to 7.5. At each value of $\mathrm{pH}$, total carbon and dissolved $\mathrm{CO}_{2}$ were calculated. The outgassing coefficient was then determined by linear regression of the average $\mathrm{CO}_{2}$ driving force with the rate of change in total carbon.

Table 3-7. $\mathrm{pH}$, Partial Pressure of $\mathrm{CO}_{2}\left(\mathrm{pCO}_{2}\right)$, and TIC Relationship for RTF Water

\begin{tabular}{lllll}
\hline $\mathrm{pH}$ & $\begin{array}{l}\mathrm{pCO}_{2} \\
(\%)\end{array}$ & $\begin{array}{l}\mathrm{CO}_{2} \\
(\mathrm{mmol})\end{array}$ & $\begin{array}{l}\mathrm{TIC} \\
(\mathrm{mmol})\end{array}$ & $\begin{array}{l}\mathrm{SD} \\
(\mathrm{mmol})\end{array}$ \\
\hline $5.10^{*}$ & 100 & 33.8 & 28.9 & 0.456 \\
6.58 & 3.62 & 1.33 & 4.58 & 0.015 \\
6.88 & 1.84 & 0.68 & 3.96 & 0.005 \\
7.18 & 0.917 & 0.34 & 3.63 & 0.008 \\
7.26 & -- & -- & 3.57 & 0.013 \\
7.47 & 0.466 & 0.17 & 3.44 & 0.010 \\
7.75 & 0.234 & 0.086 & 3.32 & 0.013 \\
8.01 & 0.119 & 0.044 & 3.21 & 0.013 \\
8.49 & -- & -- & 2.91 & 0.038 \\
\hline
\end{tabular}

* Measured at $23^{\circ} \mathrm{C}$.

Note: $-\log (\mathrm{kH})=1.435$ at $20^{\circ} \mathrm{C}$. 


\subsubsection{Carbonate Equilibria}

Calculations of the mass transfer coefficient for outgassing and the injection efficiency in the in-pond sumps both require knowledge of the carbonate equilibria. The SaW at Roswell is significantly different from either fresh water or seawater; therefore, we could not rely on published values of the dissociation constants for these waters. Instead, we directly measured the relationship between total carbon and $\mathrm{pH}$.

Table 3-7 shows the relation between total inorganic carbon, $\mathrm{pH}$, and $\mathrm{pCO}_{2}$. Solution $\mathrm{pH}$ was varied by equilibrating with different concentrations of $\mathrm{CO}_{2}$ in the gas phase. Each TIC value represents the average of five measurements. This set of measurements was done at $20^{\circ} \mathrm{C}$. The water had an alkalinity of $3.30 \pm 0.02 \mathrm{mmol}$. The accuracy error involved in estimating the carbonate alkalinity was probably several tenths of a mmol/L because of the uncertainty in the true endpoint for the titration and also because of the small amounts of other titratable bases.

The measurements shown in Table 3-7 (excluding the point at $\mathrm{pH}=5.1$ ) were combined with a previous data set and the best fit equilibrium constants were determined. The point at $\mathrm{pH}=5.1$ was not included in the fit because of uncertainties in the temperature correction and the disproportionate weighting of such a large TIC value. The curvefitting yielded $\mathrm{pK} 1=6.05$ and $\mathrm{pK} 2 *=9.37$. The standard error of the fit was calculated as $0.326 \mathrm{mmol}$. Sensitivity of the fit to changes in $\mathrm{pKL}$ or $\mathrm{pK} 2$ were determined by calculating the amount of change in either value to produce a standard error of $0.115 \mathrm{mmol}$ from the best fit case. This gave an error in pK 1 of about 0.01 and in pK 2 of about 0.2 . However, changes in the estimated value of the carbonate alkalinity resulted in large changes in the best fit values of the equilibrium constants. Assuming the true alkalinity was $0.3 \mathrm{mmol}$ higher led to a value for $\mathrm{pKL}$ that was 0.13 units lower and a value for $\mathrm{pK} 2$ that was 0.49 units lower.

Since the regressed values of the equilibrium constants were so sensitive to small errors in estimates of carbonate alkalinity, the data were analyzed with a different method. This method was based on calculating, for each data point, the ratio of dissolved $\mathrm{CO}_{2}$ to total carbon. From this, the first equilibrium constant could be calculated when $\mathrm{pH}$ is below 7.5. In this $\mathrm{pH}$ range, influence of the second dissociation on this ratio was insignificant. From four data points, pKl was valued at 6.20 with a standard deviation of 0.01 . If data points above $\mathrm{pH} 8.5$ were available, then the second constant was determined with small error. Without these points, $\mathrm{pK} 2$ could only be estimated to have been between 9.0 and 9.5 , which was insignificant because all carbonation work was performed at low $\mathrm{pH}$.

The accuracy of this method depends on the accuracy of the estimate of the Henry's Law constant. The $\mathrm{KH}^{*}$ is sensitive to temperature and ionic strength but not sensitive to the ionic distribution of the water type (Loewenthal and Marais, 1984). Using the ionic strength of $0.264 \mathrm{M} \mathrm{SaW}$ (calculated from the measured composition) and an empirical relationship for the ratio of the activity of $\mathrm{CO}_{2}$ in pure water to that in the test water (natural logarithm of the activity ratio $=0.22 \times$ ionic strength), a Henry's Law constant at $20 \mathrm{CO}_{2}$ of $0.0367(\mathrm{pKH}=1.435)$ was calculated. When $\mathrm{KH}$ was calculated from the

${ }^{*} \mathrm{pK} 1=-\log$ (first ionization constant for dissociation of carbonic acid)

$\mathrm{pK} 2=-\log$ (second ionization constant for dissociation of bicarbonate to carbonate)

${ }^{*} \mathrm{KH}=$ Henry's Law Constant for the concentration of a solute in a solution at a given partial pressure. 
comparison of the gas partial pressure of $\mathrm{CO}_{2}$ (as given in Table 3-7) and the dissolved $\mathrm{CO}_{2}$ predicted by the regressed equilibrium constants, pKH was greater than 1.50, which is greater than that of seawater. This discrepancy could easily be attributed to errors in the equilibrium constants as estimated by regression. In the future, these will be reestimated on the basis of Gran titrations.

\subsubsection{Injection Efficiency}

The experiments were designed to test the sensitivity of the injection efficiency (IE) to variations in height above diffuser and gas flow rate. Results are shown in Tables 3-8 and 3-9 for the sump and tank tests, respectively. The data for the sumps were used to yield three estimates of IE: one based on the regressed values for the equilibrium constants, one based on the actual TIC measurements (points for which the IE test endpoints corresponded closely to pH-TIC measurements as given in Table 3-7), and one based on the $\mathrm{pK} 1$ as determined from the Henry's Law constant. IE averaged 76\% by the first method, $90 \%$ by the second, and $100 \%$ by the third. Visual observation of the bubbles breaking the surface during the tests indicated a very high IE. Clearly, the first method underestimated the IE, while the third method overestimated it. Given the magnitude of the errors involved, the true IE was most likely in the range of $80 \%-90 \%$.

A more important result of the experiments is that despite variation in gas flow rate and liquid height, little change in IE occurred. Although there is uncertainty about the absolute value of the calculated injection efficiencies, these results are significant in that they corroborate a high IE value. So much gas was absorbed that the bubbles became minuscule. This would results in very little bubble "slip" relative to the liquid. A lack of dependence on the gas flow rate indicates that the hydrodynamic condition is only slightly altered by changes in the gas flow rate.

\subsubsection{Outgassing}

The outgassing coefficient was determined at two mixing speeds for the lined North pond (see Table 3-10). Measuring outgassing rates in the South (unlined) pond was difficult because of a small amount of photosynthetic uptake of $\mathrm{CO}_{2}$ during the experiments (from sediment activity); therefore, these rates are not reported here.

Each of the reported values represents two measurements. The uncertainty in individual measurements ranged between 15\%-30\% of the regressed value of KL (the coefficient of mass transfer for outgassing $\mathrm{CO}_{2}$ ). Because determination of the outgassing coefficient involves the derivative of the collected data, a small error (or noise) in the $\mathrm{pH}$ measurement can result in a large error in the rate of change in total carbon and therefore increase the uncertainty in $\mathrm{KL}$. In some cases discrepancies in $\mathrm{pH}$ measurements were the result of the discrete nature of the measurement process (versus continuous). A source of systematic error results from the uncertainty concerning the carbonate equilibria. The error is introduced because of possible deviations between the calculated TIC, and the true TIC, or more specifically errors in the slope, dTIC/dt, over the region of $\mathrm{pH}$ change. Fortunately over the range of $\mathrm{pH}$ values where $\mathrm{dTIC} / \mathrm{dt}$ is calculated, there is negligible difference between measured rates of change and those determined by the equilibrium expressions. 
Table 3-8. Summary of Carbonation Tests in Sump

\begin{tabular}{|c|c|c|c|c|c|c|c|c|}
\hline \multirow{2}{*}{$\begin{array}{c}\text { Run } \\
\text { 非 }\end{array}$} & \multirow{2}{*}{$\begin{array}{l}\text { Depth } \\
\text { (m) }\end{array}$} & \multirow{2}{*}{$\begin{array}{l}\text { Width } \\
(\mathrm{m})\end{array}$} & \multirow{2}{*}{$\begin{array}{c}\text { Volume } \\
\left(\mathrm{m}^{3}\right)\end{array}$} & \multirow{2}{*}{$\begin{array}{l}\mathrm{QCO}_{2} \\
(\mathrm{slpm})\end{array}$} & \multirow{2}{*}{$\begin{array}{r}\text { dTICg* } \\
(\mathrm{mol})\end{array}$} & \multicolumn{3}{|c|}{ Efficiency (\%) } \\
\hline & & & & & & 1 & 2 & 3 \\
\hline l & 0.88 & 0.72 & 4.34 & 71 & 4.55 & 81 & 96 & 117 \\
\hline 2 & 0.58 & 0.76 & 3.05 & 65 & 4.15 & 81 & -- & 106 \\
\hline 3 & 0.58 & 0.76 & 3.05 & 44 & 3.71 & 80 & 91 & 102 \\
\hline 4 & 0.58 & 0.76 & 3.05 & 24 & 3.79 & 78 & 88 & 94 \\
\hline 5 & 0.88 & 0.72 & 4.34 & 24 & 3.79 & 70 & 88 & 88 \\
\hline 6 & 0.88 & 0.72 & 4.34 & 45 & 3.79 & 71 & 89 & 94 \\
\hline 7 & 0.88 & 0.72 & 4.34 & 70 & 4.51 & 73 & 91 & 97 \\
\hline
\end{tabular}

* dTICg is amount of $\mathrm{CO}_{2}$ injected, calculated as flow rate $\times$ duration of injection.

Method 1--based on nonlinear regression to determine pK1, pK2.

Method 2--based on measured TIC at pH before and after injection.

Method 3--based on Raoult's Law to determine pK1.

Table 3-9. Summary of Carbonation Tests in 600-L Tank

\begin{tabular}{cccccc}
\hline $\begin{array}{c}\text { Run } \\
\#\end{array}$ & $\begin{array}{c}\text { Depth } \\
(\mathrm{m})\end{array}$ & $\begin{array}{c}\text { Volume } \\
(\mathrm{m} 3)\end{array}$ & $\begin{array}{c}\mathrm{QCO}_{2} \\
(\mathrm{slpm})\end{array}$ & $\begin{array}{c}\text { dTICg } \\
(\mathrm{mol})\end{array}$ & $\begin{array}{c}\text { Efficiency } \\
(\%)\end{array}$ \\
\hline 1 & 1.07 & 0.54 & 15 & 0.85 & $59(73)$ \\
2 & 1.07 & 0.54 & 15 & 1.34 & 65 \\
3 & 1.02 & 0.51 & 15 & 1.34 & 62 \\
4 & 1.07 & 0.54 & 15 & 1.88 & 62 \\
5 & 1.07 & 0.54 & 65 & 2.99 & 57 \\
6 & 1.07 & 0.54 & 15 & 2.01 & 63 \\
7 & 1.07 & 0.54 & 11 & 1.56 & 63 \\
8 & 0.84 & 0.43 & 15 & 1.07 & 58 \\
9 & 0.61 & 0.32 & 15 & 0.80 & 57 \\
10 & 0.61 & 0.32 & 15 & 0.80 & 57 \\
11 & 0.38 & 0.22 & 15 & 0.54 & 59 \\
$12 *$ & 1.07 & 0.54 & 15 & 1.25 & 64 \\
\hline
\end{tabular}

*Hand-mixed during sparging.

Note: All values calculated by method 1 , except for value in ( ), which was calculated from method 2 .

\subsubsection{Conclusions}

The 80\%-90\% injection efficiency measured for the large-scale carbonation system needs improvement. The data indicate that increasing the height of the water column in the carbonation sump is ineffective in increasing injection efficiency. The most likely explanation for this is that after most of the $\mathrm{CO}_{2}$ was absorbed, the remaining bubbles were so small that there was relatively little motion between the water and the gas. This resulted in the formation of a substantial local back pressure which greatly slowed absorption. The $\mathrm{pH}$ of these local volumes of water would have to have been about 5 , depending on how much the bubble $\mathrm{CO}_{2}$ content was diluted by nitrogen and oxygen absorbed from the water. The most effective manner of increasing the absorption efficiency would appear to increase the turbulence in the sump. In the actual operation 
Table 3-10. Summary of Outgassing Results

\begin{tabular}{cccc}
\hline $\begin{array}{c}\text { Depth } \\
(\mathrm{m})\end{array}$ & $\begin{array}{c}\text { Velocity } \\
(\mathrm{m} / \mathrm{s})\end{array}$ & $\begin{array}{c}\mathrm{KL} \\
(\mathrm{m} / \mathrm{s})\end{array}$ & $\begin{array}{c}\mathrm{SD} \\
(\mathrm{m} / \mathrm{s})\end{array}$ \\
\hline 0.15 & 0.17 & $1.2 \times 10^{-5}$ & $0.03 \times 10^{-5}$ \\
0.15 & 0.31 & $2.0 \times 10^{-5}$ & $0.33 \times 10^{-5}$ \\
\hline
\end{tabular}

of the ponds, this occurs--the gas is injected countercurrently into water flowing into and out of the sump. However, outgassing of oxygen (the concentration of which in the ponds was well above air saturation levels) may decrease absorption efficiency by decreasing the $\mathrm{PCO}_{2}$ in the bubbles. As discussed in Section 4, the estimated in situ efficiency is no higher than the efficiency measured in these tests, despite the countercurrent operation. If so, it may be necessary to install a system for capturing the gas and recycling it through the injection system.

Outgassing of $\mathrm{CO}_{2}$ through the pond surface can be extensive if mixing is too energetic and $\mathrm{pH}$ too low. However, it can be made negligible by optimized operation of the ponds. Given the values of the outgassing coefficients, $\mathrm{pH}$ should be maintained above 8 to reduce outgassing losses to less than $10 \%$. The effect of this on algal productivity is discussed in Section 5. 


\subsection{OPERATION OF THE LARGE-SCALE SYSTEM}

Most of the activity concerning the two 0.1-ha raceways centered around the engineering analyses discussed in Section 3. In addition, however, the process of evaluating the biological performance of the large-scale system began during this subcontract period. The two raceways began operation in August 1988 with the inoculation of Tetraselmis etroselmis suecica TETRAl. Since it was evident that pond hydraulics were not yet optimized, the paddle wheel rotation speed was set at $5.3 \mathrm{rpm}$ to try to alleviate in-pond sedimentation of biomass. This resulted in an average mixing velocity of $30 \mathrm{~cm} / \mathrm{s}$ in the lined pond and $22 \mathrm{~cm} / \mathrm{s}$ in the unlined pond.

T. suecica grew from the middle of August to the middle of September, averaging $11 \mathrm{~g}$ ash free dry weight (AFDM) $/ \mathrm{m}^{2} / \mathrm{d}$ in the North (lined) pond and $10 \mathrm{~g} \mathrm{AFDM} / \mathrm{m} / \mathrm{d}$ in the South (unlined) pond. Even with the higher mixing speed, frequent sweeping of the bottom of the North (lined) pond showed that settling of biomass was significant. Suspended solids ranged from $10 \%$ to $100 \%$ higher after sweeping, This action may have contributed to poor yield by the large ponds versus the $3-\mathrm{m}^{2}$ ponds. In the latter, T. suecica grew stably through the fall and winter, averaging $15.2 \mathrm{~g} \mathrm{AFDM} / \mathrm{m}^{2} / \mathrm{d}$ over a comparable time period.

After the loss of T. suecica from the large-scale ponds, Monoraphidium minutum was inoculated, It was also cultivated in the $50-\mathrm{m}^{2}$ inoculum pond for comparison, as well as in the $3-\mathrm{m}^{2}$ ponds. As shown in Table 4-1, productivity was highest in the smallest ponds, but not much higher than in the North (lined) ponds (the lined 0.1-ha pond and the inoculum pond). Productivity was lowest in the large, South (unlined) pond. Significant biomass settling was observed once again in both of the 0.1-ha ponds. The inability to clean the south unlined pond (by mechanical resuspension of settled matter) was a distinguishing characteristic. Whether this or some other factor was the reason for lower production from this pond is unknown. During the month of December, yields were low in all ponds because of the cold weather.

An important aspect of the difference between membrane-lined ponds and unlined ponds is the loss of water through leaks and percolation. The average daily loss of water, including evaporation, is given in Table 4-2 for the large-scale system raceways. Initially, seepage from the unlined pond was visible as water around the pond periphery. Leaks were evident between the concrete mixing structures and the clay lining. After these were fixed, percolation still occurred. Nearly one-half of a centimeter per day more water was lost from the unlined pond than from the lined pond. However, after approximately 30 days of operation, the water loss from the ponds equalized at the lower rate of $0.4 \mathrm{~cm} / \mathrm{d}$. Apparently the unlined pond had sealed. Subsequently, the pond was emptied to take some engineering measurements. The pond bottom dried out completely. When refilled, the unlined pond again incurred a greater water loss than the lined ponds. Although the extra loss of water was now less (about $0.3 \mathrm{~cm} / \mathrm{d}$, there has been no amelioration of the rate. Thus, it is likely that the drying process led to the formation of new leaks. This element will be examined next year.

A preliminary mass balance for carbon was calculated for the North (lined) 0.1-ha raceway. The amount of $\mathrm{CO}_{2}$ injected into the sump was monitored with a calibrated mass flow meter. The mass of carbon fixed into biomass was estimated as half of the AFDM produced. Finally, carbon lost to the atmosphere through outgassing was estimated from the mass transfer coefficient as a function of average operating pH. The results of the trial mass balances are shown in Table 4-3. Overall utilization efficiency of $\mathrm{CO}_{2}$-carbon varied from a low of $32 \%-65 \%$. The low efficiency was caused by low, winter biomass productivity. More $\mathrm{CO}_{2}$ was lost to the atmosphere than was fixed in biomass. When 
Table 4-1. Large-scale System Productivity (g AFDM $/ \mathrm{m}^{2} / \mathrm{d}$ )

\begin{tabular}{lcccc}
\hline & Lined Pond & Unlined Pond & $50-\mathrm{m}^{2}$ Pond & 3- $\mathrm{m}^{2}$ Pond \\
\hline $9 / 2-9 / 17$ & 13.1 & 10.8 & -- & 16.4 \\
$9 / 23-11 / 2$ & 12.5 & 7.0 & 9.4 & 14.4 \\
$11 / 3-11 / 30$ & 5.0 & -- & 4.5 & $9.4^{*}$ \\
$12 / 1-12 / 26$ & 3.2 & 2.1 & 1.8 & $3.5^{*}$ \\
\hline
\end{tabular}

* 1987 results.

Note: $50-\mathrm{m}^{2}$ pond is lined; $3-\mathrm{m}^{2}$ pond is fiberglass.

Table 4-2. Average Daily Water Loss from Large-scale Ponds (cm/day)

\begin{tabular}{lccc}
\hline & Lined Pond & Unlined Pond & $50-\mathrm{m}^{2}$ Pond \\
\hline $9 / 2-2 / 17$ & $0.32(0.52)$ & $0.79(0.19)$ & - \\
$10 / 9-11 / 13$ & $0.36(0.34)$ & $0.40(0.20)$ & $0.37(0.25)$ \\
$11 / 28-12 / 26$ & $0.11(0.13)$ & $0.43(0.13)$ & $0.16(0.13)$ \\
\hline
\end{tabular}

Table 4-3. Carbon Utilization Efficiency in Lined Pond

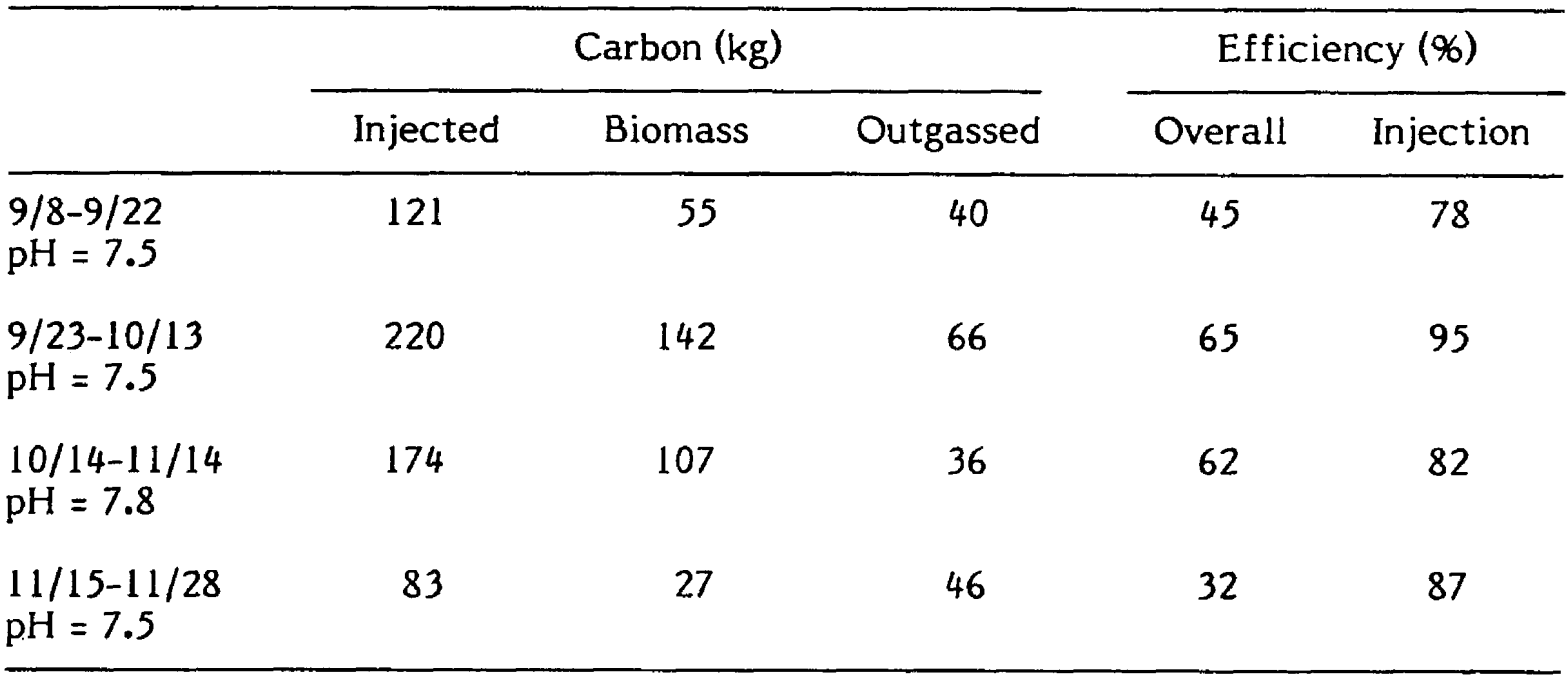


productivity averaged about $10 \mathrm{~g} \mathrm{AFDM} / \mathrm{m}^{2} / \mathrm{d}$, outgassing represented $30 \%$ of the injected $\mathrm{CO}_{2}$ at $\mathrm{pH} 7.5$ and $20 \%$ at an operating $\mathrm{pH}$ of 7.8. As noted in Section 3.8, to achieve over $90 \%$ overall $\mathrm{CO}_{2}$ utilization efficiency, the $\mathrm{pH}$ of the ponds must be kept above 8.0 . The injection efficiency of the sumps, operated countercurrently, was $78 \%$ $95 \%$.

In summary, the results from the large-scale raceways have been mixed One species, $T$. suecica, was not as productive in the larger ponds versus the $3-\mathrm{m}^{2}$ ponds, while another species, M. minutum, was about as productive. The South (unlined) pond tended to have reduced yields and more difficulties with settling. Much more discriminating results will be obtained when the ponds are operated over long periods during which yields are potentially high. In addition, some of the problems with mixing and suspension will have been examined by then. Operation of the South (unlined) pond consumed more water than the North (lined) ponds due to leaks and percolation. The leaks appeared to predominate; they also can probably be fixed. Under the worst conditions observed, water usage in the unlined system would be $50 \%$ greater than in the lined system. However, there is evidence that the unlined system can seal effectively. $\mathrm{CO}_{2}$ utilization efficiency was low (60\%), but this was mainly due to outgassing. This loss can be minimized by operating at a higher $\mathrm{pH}$. 


\subsection{OPERATION OF THE SMALL-SCALE SYSTEM}

\subsection{Experimental Plan}

The small-scale system was used to test 15 species for growth in the mass culture environment, to assess the effects of moderately low $\mathrm{CO}_{2}$ and moderately high $\mathrm{pH}$ (conditions which improve the economics of pond operation) on productivity and stability, and to evaluate capability for induction of high-lipid content in the organisms tested.

Last year, we found that $M$. minutum grew stably during the cold seasons, even surviving freezes. It was cultivated during January, February, March, April, and May, and again during October and November of 1988. During January, February, and April, it was grown in unheated ponds as well as in heated ponds. During the first two months, each condition was performed in duplicate. Other heating experiments were also performed, for two weeks at a time, during May and June to see whether raising pond temperatures would increase productivity of warm weather species (e.g., T. suecica TETRA1) and affect species dominance.

During the warm and sunny months of May through September, we could of ten operate the raceways on a two-day hydraulic detention time. However, extended periods of cloud cover can cause instability of culture density. Therefore, we compared productivity of cultures operated on a three-day detention to that of cultures operated on a two-day regime. A three-day regime is much more stable. Two warm weather organisms, which grow quite stably, were used in these two-week trials: Amphora sp. (RTF) and T. suecica TETRAl.

Since $\mathrm{CO}_{2}$ is a major input to the system, and its loss via outgassing is increased at low

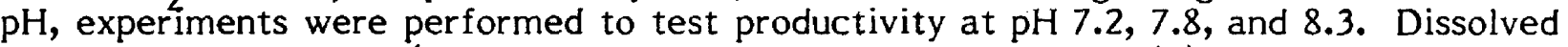
concentrations of $\mathrm{CO}_{2}$ (at the alkalinity of 3 to 5 milliequivalent/L) were about 285, 75, and $20 \mu \mathrm{m}$, respectively, at these $\mathrm{pH}$ values.

All of the organisms that were stable in culture (that is, could be grown for at least two to three weeks) were tested for the capability to produce lipids under nutrient stress. These experiments were usually conducted singly, but were repeated. Samples were preserved for subsequent lipid analysis at the Solar Energy Research Institute (SERI).

\subsection{Materials and Methods}

The small-scale system consists of six $2.74-\mathrm{m}^{2}$ fiberglass tanks operated at $15-\mathrm{cm}$ depth, mixed by paddle wheel, and $\mathrm{pH}$ controlled by injection of $100 \% \mathrm{CO}_{2}$ on demand. Two $1000-W$ heaters were available per pond to maintain a given minimum temperature for experiments performed during the fall and winter.

We prepared $900 \mathrm{~L}$ of media in each of three polyethylene tanks. The tanks were mounted at ground level, and media were pumped into the ponds. RTF SaW was the only water resource used (see Table A-1). Urea $(3.6 \mathrm{mmol}$ ), anhydrous dipotassium phosphate $(0.2 \mathrm{mmol})$, silica (as needed for diatoms, added at $4.7 \mathrm{mmol}$, neutralized with $\mathrm{HCl}$ on a 2:1 mol:mol basis), and chelated iron $(0.1 \mathrm{mmol}$ iron sulfate premixed with $2: 1$, mol:mol EDTA) were added to the nutrient tanks. Alkalinity was typically $3.5 \mathrm{mmol}$ and derived from the water used.

Daily measurements included minimum and maximum ambient temperatures and insolation (Li-Cor 1776 integrating solar monitor with 200SB pyranometer sensor), minimum/ maximum culture temperatures, $\mathrm{pH}$, ash-free biomass density, and culture depth. The $\mathrm{pH}$ 
was checked several times each day to see that it was within limits. Cultures were diluted continuously 8-14 h/d (depending on temperature and insolation) from MayOctober using Masterflex peristaltic pumps on both the influent and effluent lines. Effluents were sampled every hour and composited. The composite samples were kept fresh in a refrigerator. Daily productivity was calculated as grams AFDM harvested (mass per liter of the composited samples, multipled by liters harvested) divided by $2.74 \mathrm{~m}^{2}$ (pond area). Because of the continuous nature of the dilution, any given productivity that was calculated represented a smoothed average value. During periods of potential freezing temperatures, cultures were operated as sequential batches.

Inoculum was grown indoors in $750-\mathrm{mL}$ and $8-\mathrm{L}$ cultures, incubated at $25^{\circ}$ to $30^{\circ} \mathrm{C}$ at $\mathrm{pH}$ 7.5, under continuous illumination (cool, white fluorescent bulbs) at about $200 \pm 20 \mu \mathrm{E} \mathrm{m} / \mathrm{s}$, and at saturating $\mathrm{CO}_{2}(1.0 \%$ in air, injected continuously through glass bubblers at a rate of $0.33-0.5 \mathrm{v} / \mathrm{v} / \mathrm{min}$.

We measured AFDM by filtering $5-10 \mathrm{mg}$ of cells (estimated AFDM) on GF/C (Whatman) filters, rinsing with $50-100 \mathrm{~mL}$ of isotonic $\mathrm{NaCl}$ solution, drying at $103^{\circ} \mathrm{C}$ for $1 \mathrm{~h}$, weighing on a five-place electronic balance (Mettler AE240), ashing for $20 \mathrm{~min}$ at $550^{\circ} \mathrm{C}$, weighing again, and using the difference as the dry mass. The drying times were sufficiently long to reach constant weight.

Heat of combustion was estimated at $6 \mathrm{kcal} / \mathrm{g}$ AFDM. Photosynthetic efficiency was calculated based on photosynthetically active radiation (using $45 \%$ of the cumulated outdoor energy input) and the estimated heat of combustion to convert from mass units to thermal units.

Calibrations of pond areas, pond depth-volume relationships, and effluent tank depthvolume relationships were made. The pond area was $2.74 \mathrm{~m}^{2}$. Potential shading from sidewalls was reduced by minimizing sidewall freeboard (at $15-\mathrm{cm}$ depth, freeboard was $8 \mathrm{~cm}$ ) and by orienting the ponds so that the short dimension was in the north-south direction. Although this exacerbated sidewall shading in the winter when the sun is in the southern sky, pond depth could be raised if the problem was significant (as discussed later, temperature was the limiting factor in the winter). Paddle-wheel shading was minimized by building the wheels of clear polycarbonate. No adjustments in the productivity were made for any of these potential shading problems. The volume per centimeter of pond depth was less at the pond bottom because of the rouding of the bottom-sidewall joint and the very slight trapezoidal shape of the ponds. Above the first few centimeters, each pond contained contained $28.5+0.5 \mathrm{~L} / \mathrm{cm}$. When necessary, the actual depth-volume calibration for each pond was used. The effluent tanks were straightwalled cylinders with conical bottoms. Each was independently calibrated for depthvolume. The typical relationship was: volume $(\mathrm{L})=18+4.9 \times \operatorname{depth}(\mathrm{cm})$.

\subsection{Results}

\subsubsection{Overall Results}

Fifteen organisms were inoculated into outdoor cultures. Two species invaded: the Amphora sp. that was present during the previous year and a Cyclotella sp. that was isolated from a bloom in the 0.1-ha raceways. Six of these could be cultured: Chaetoceros muelleri CHAET9, Chaetoceros muelleri CHAET63, the indigenous Amphora, the indigenous Cyclotella, T. suecica TETRA1, and M. minutum MONOR2. The 10 that could not be cultured were Chlorella sp. 12P, Nitzschia sp. NIT2, Chaetoceros muelleri CHAET61, Green 7.1, Green 7.2, Nannochloropsis sp. NANNP2, Nannochloris sp. 
NANNO2, Cyclotella cryptica CYCLO1, Thallasiosira fluviatilis, and Thallasiosira sp. THAL1.

Of the unsuccessful cultivation attempts, a few may have been caused by the poor quality of the inoculum used. Both Cyclotella cryptica CYCLOI and THALl failed, never showing any significant growth. This response was certainly unexpected with CYCLOI since it had grown so well last year. Other species did show initial growth, but soon became contaminated with the indigenous Amphora and then dominated by TETRA1. For instance, NANNP2 grew from 50 to $300 \mathrm{mg} / \mathrm{L}$ (with a maximum productivity of $16 \mathrm{~g} \mathrm{AFDM} / \mathrm{m}^{2} / \mathrm{d}$ ) but was lost after successive blooms of the two competitors along with other indigenous green algae. The same pattern was observed with NANNO2.

The daily insolation for 1988 is shown in Figure 5-1. The ambient and typical pond temperatures are shown in Figures 5-2 and 5-3, respectively. The overall productivity results for the year are shown in Table 5-1. Two strains were found to be stable during the coldest months: $M$. minutum and T. suecica. Five species performed well during the warm season: T. suecica, Cyclotella sp. RTF, Amphora sp. RTF, Chaetoceros muelleri CHAET9, and Chaetoceros muelleri CHAET63. All of the results shown in this table are from unheated cultures. The weather was quite similar during 1987 and 1988, as was the species succession.

Productivities were very low during the coldest months (December, January, and February). Severe conditions of ice or slush in the small ponds every day limited our ability to dilute the cultures. Of course, growth was very slow anyway. The productivities averaged 25 to $30 \mathrm{~g} \mathrm{AFDM} / \mathrm{m}^{2} / \mathrm{d}$ during the warm months of May, June, July, and August. Because of our efforts to screen many species, the most productive organisms were not cultivated during most of July and August. Yields of about $20 \mathrm{~g} \mathrm{AFDM} / \mathrm{m}^{2} / \mathrm{d}$ were obtained from several strains during the transition months of September and October. These months have $10 \%$ to $20 \%$ less insolation than the months of April and March, but are much warmer. We believe the productivities may be improved for the months of March and April. If $15-20 \mathrm{~g} \mathrm{AFDM} / \mathrm{m}^{2} / \mathrm{d}$ were attained during these two months as well, the yearly average would be close to $20 \mathrm{~g} \mathrm{AFDM} / \mathrm{m}^{2} / \mathrm{d}$ rather than the $16 \mathrm{~g} \mathrm{AFDM} / \mathrm{m}^{2} / \mathrm{d}$ achieved in 1988. The greater thermal insulation of the large-scale raceways compared with the $3-\mathrm{m}^{2}$ raceways will help keep pond temperatures higher during the transition months, which may improve yields.

The results from all the species (in unheated ponds) are shown in Table 5-2 and Figures 5-4 through 5-7. As we have seen in previous years, the diatoms were more productive than the green algae.

\subsubsection{Effects of Heating}

Results of experiments with heating as a variable are shown in Table 5-3. As was observed last year, heating had little effect on the productivity of the cultures. The ponds were only heated during the day, from 0600 (or 0800) to 1300 (or 1600). Thus, the minimum and maximum temperatures reached in the heated ponds were about the same as those reached in the unheated ponds. Any effects due to low overnight temperatures would have been the same in both cases. The conditions, coupled with the generally unfavorable growth conditions during the winter, kept all productivities low during this time. The heated ponds were more productive, but still productivity was very low (photosynthetically active radiation efficiency was also very low). The major effect of the heating was to raise pond temperatures $10^{\circ} \mathrm{C}$ by $0900-1000$ hours during the winter and $15^{\circ}-20^{\circ} \mathrm{C}$ by that time during the spring. Although not much effect was expected during the winter, little was seen during April either. However, there were mitigating factors. 


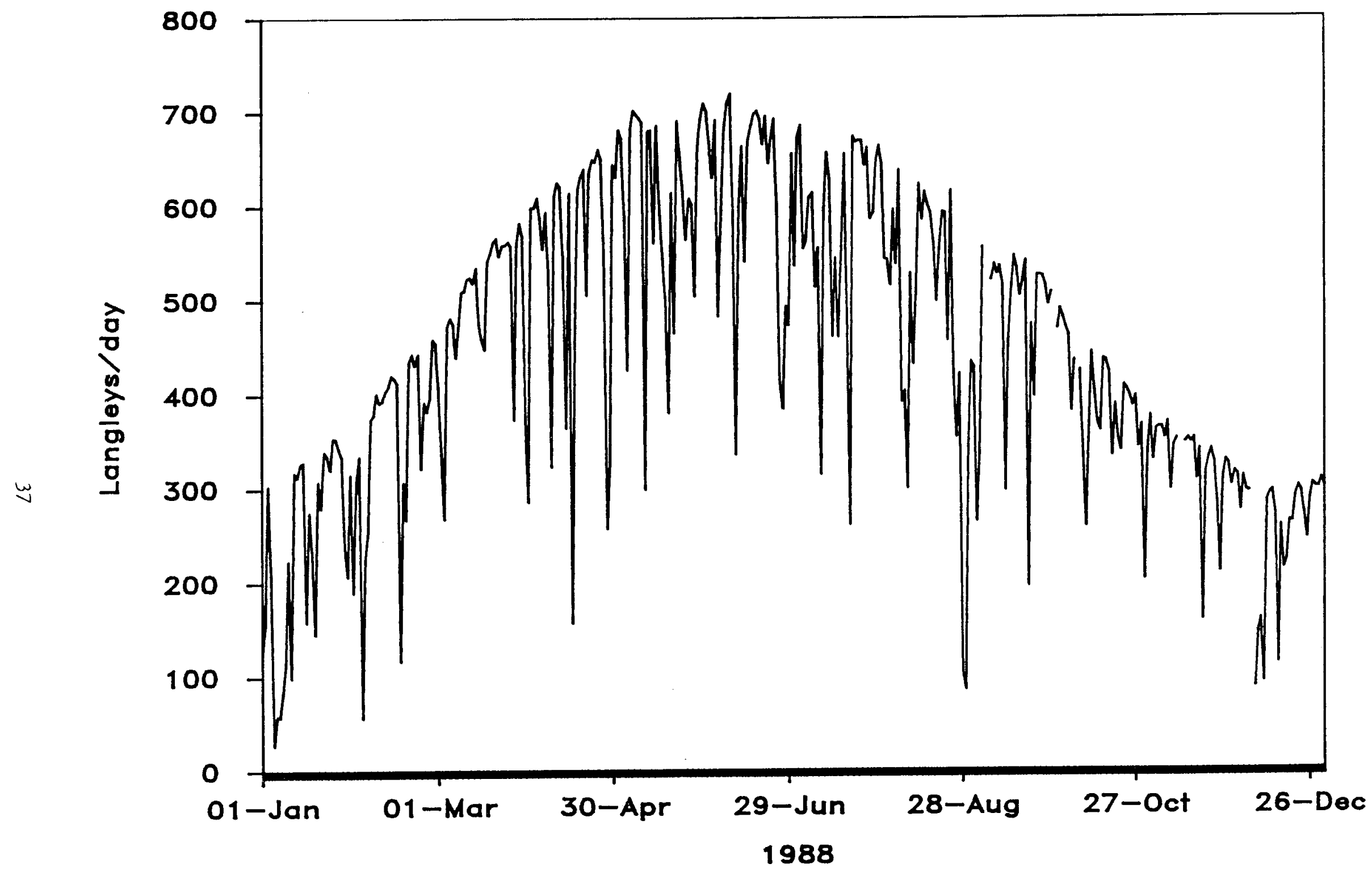

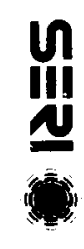

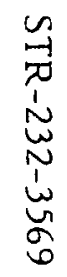

Figure 5-1. Daily total insolation at the Roswell Test Facility, N. Mex. 


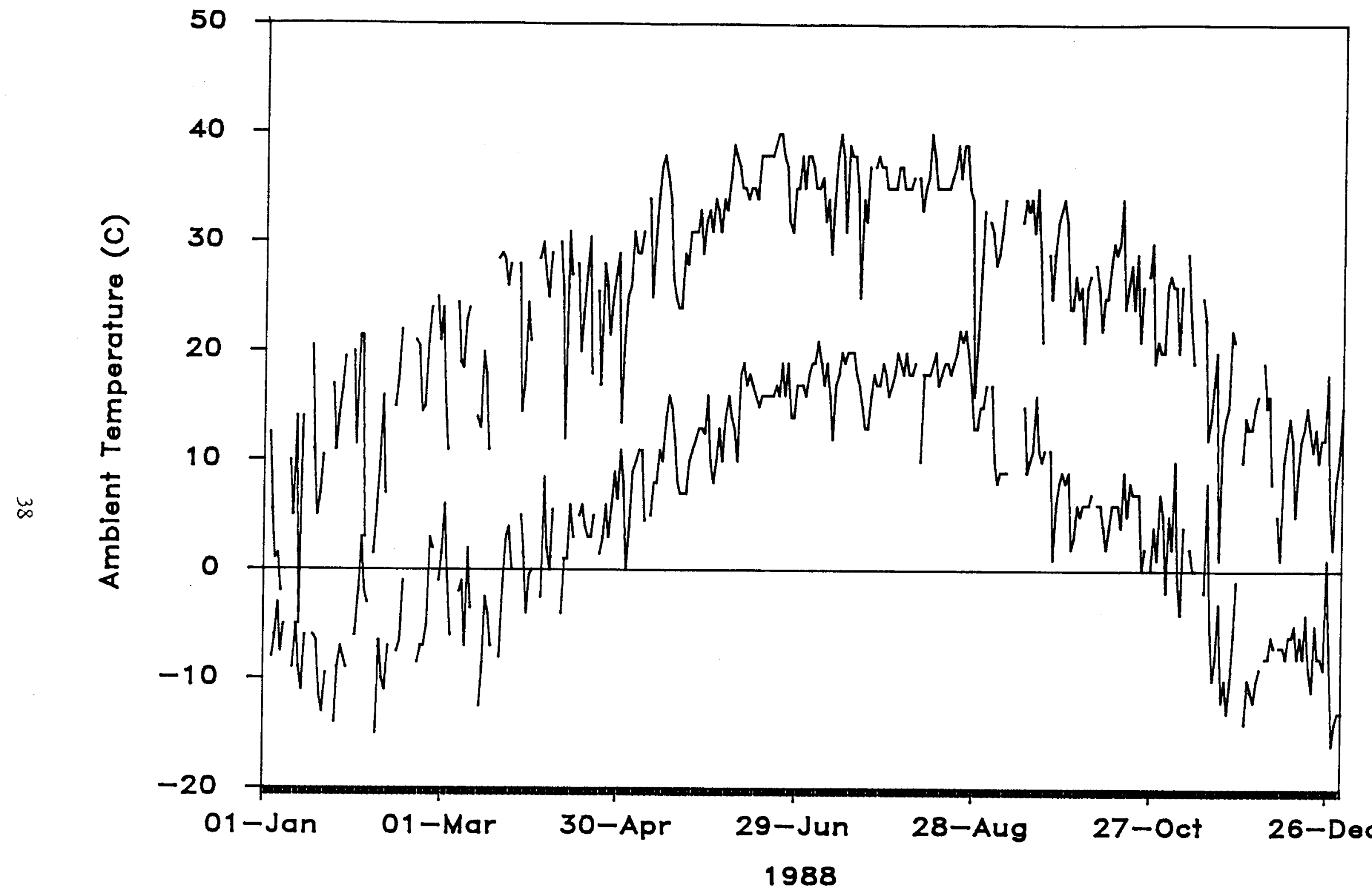

Figure 5-2. Maximum and minimum air temperatures at the Roswell Test Facility, N. Mex. 


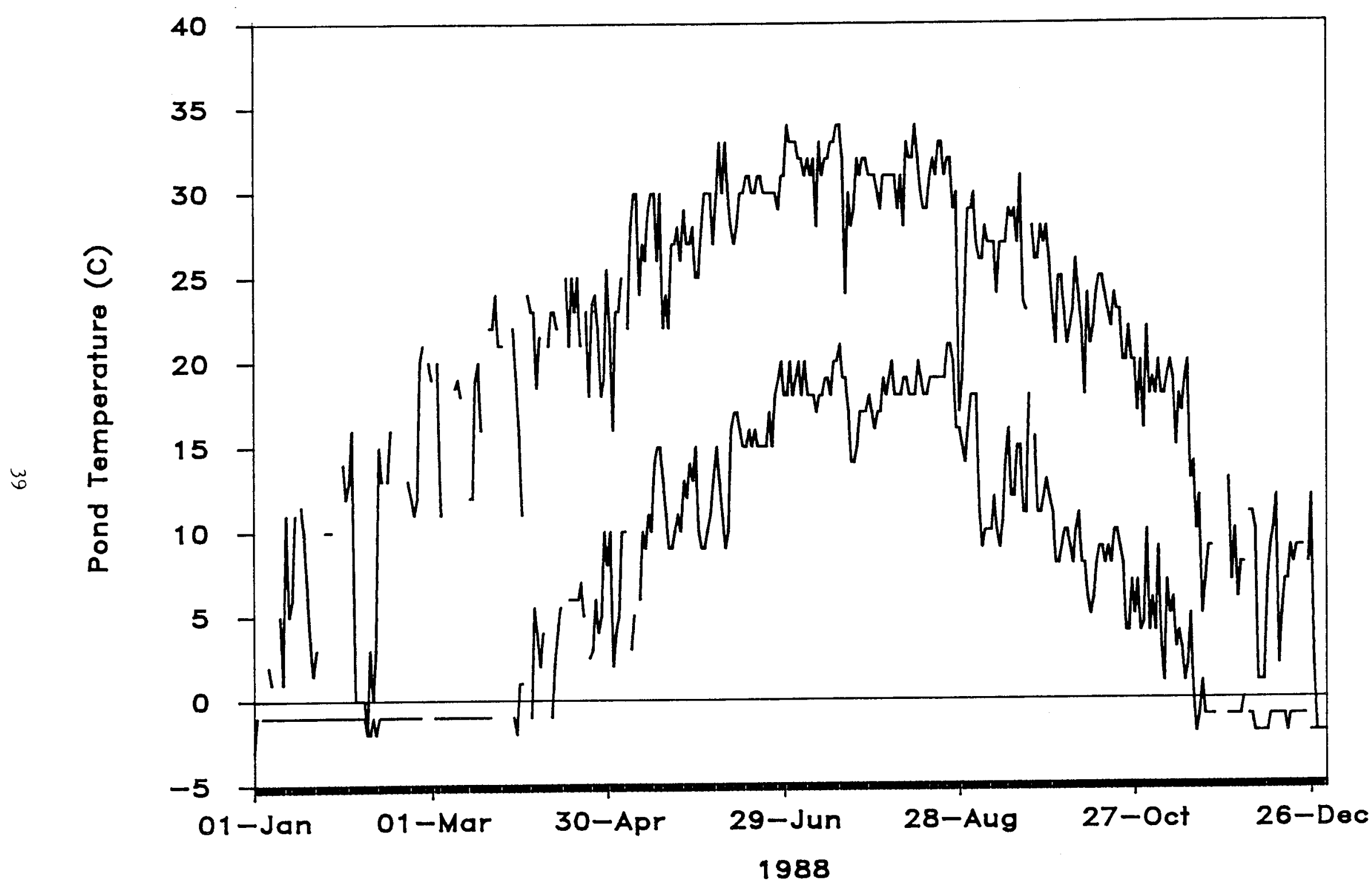

Figure 5-3. Maximum and minimum temperatures in unheated ponds 
Table 5-1. Monthly Productivity Results from 3-m² Algal Cultures

\begin{tabular}{|c|c|c|c|c|c|c|}
\hline Month & $\begin{array}{l}\text { Insolation } \\
\left(\mathrm{cal} / \mathrm{cm}^{2} / \mathrm{d}\right)\end{array}$ & $\begin{array}{l}\text { Ambient T } \\
\max \left({ }^{\circ} \mathrm{C}\right)\end{array}$ & $\begin{array}{l}\text { emperature } \\
\min \left({ }^{\circ} \mathrm{C}\right)\end{array}$ & $\begin{array}{l}\text { Productivity } \\
\left(\mathrm{g} \text { AFDM } / \mathrm{m}^{2} / \mathrm{d}\right)\end{array}$ & $\begin{array}{c}\text { Efficiency } \\
\text { (\%PAR) }\end{array}$ & Species \\
\hline Jan. & $\begin{array}{l}235 \\
(104)\end{array}$ & $\begin{array}{c}9.6 \\
(7.2)\end{array}$ & $\begin{array}{l}-8.1 \\
(2.7)\end{array}$ & $\begin{array}{c}1 \\
(2)\end{array}$ & 0.4 & MONOR2 \\
\hline Feb. & $\begin{array}{l}353 \\
(102)\end{array}$ & $\begin{array}{l}15.4 \\
(7.1)\end{array}$ & $\begin{array}{l}-4.8 \\
(4.6)\end{array}$ & $\begin{array}{c}2 \\
(4)\end{array}$ & 0.8 & MONOR2 \\
\hline Mar. & $\begin{array}{l}494 \\
(77)\end{array}$ & $\begin{array}{l}20.9 \\
(5.9)\end{array}$ & $\begin{array}{l}-2.0 \\
(4.7)\end{array}$ & $\begin{array}{c}8 \\
(7)\end{array}$ & 2.2 & MONOR2 \\
\hline Apr. & $\begin{array}{l}537 \\
(138)\end{array}$ & $\begin{array}{l}25.5 \\
(4.7)\end{array}$ & $\begin{array}{c}3.4 \\
(3.2)\end{array}$ & $\begin{array}{c}12 \\
(10)\end{array}$ & 3.0 & MONOR2 \\
\hline May & $\begin{array}{l}606 \\
(104)\end{array}$ & $\begin{array}{l}29.4 \\
(5.1)\end{array}$ & $\begin{array}{c}9.8 \\
(3.6)\end{array}$ & $\begin{array}{l}29 \\
(6)\end{array}$ & 6.4 & $\begin{array}{l}\text { MONOR2 to } \\
\text { AMPHO }\end{array}$ \\
\hline June & $\begin{array}{c}616 \\
(106)\end{array}$ & $\begin{array}{l}35.9 \\
(2.6)\end{array}$ & $\begin{array}{l}15.2 \\
(2.8)\end{array}$ & $\begin{array}{l}33 \\
(4)\end{array}$ & 6.7 & AMPHO \\
\hline July & $\begin{array}{c}582 \\
(103)\end{array}$ & $\begin{array}{l}35.4 \\
(3.2)\end{array}$ & $\begin{array}{l}17.5 \\
(2.2)\end{array}$ & $\begin{array}{l}21 \\
(3)\end{array}$ & 4.8 & $\begin{array}{l}\text { TETRA1 or } \\
\text { CHAET } 9\end{array}$ \\
\hline Aug. & $\begin{array}{c}484 \\
(139)\end{array}$ & $\begin{array}{l}34.5 \\
(5.0)\end{array}$ & $\begin{array}{l}18.0 \\
(2.6)\end{array}$ & $\begin{array}{l}26 \\
(3)\end{array}$ & 7.7 & AMPHO \\
\hline Sept. & $\begin{array}{l}473 \\
(94)\end{array}$ & $\begin{array}{l}30.2 \\
(3.8)\end{array}$ & $\begin{array}{l}9.8 \\
(3.9)\end{array}$ & $\begin{array}{l}22 \\
(7)\end{array}$ & 6.2 & AMPHO \\
\hline Oct. & $\begin{array}{l}388 \\
(62)\end{array}$ & $\begin{array}{l}25.7 \\
(3.6)\end{array}$ & $\begin{array}{l}5.0 \\
(2.3)\end{array}$ & $\begin{array}{l}20 \\
(2)\end{array}$ & 7.0 & $\begin{array}{l}\text { CYCLO or } \\
\text { AMPHO }\end{array}$ \\
\hline Nov.* & $\begin{array}{l}326 \\
(46)\end{array}$ & $\begin{array}{l}18.7 \\
(6.8)\end{array}$ & $\begin{array}{l}-3.6 \\
(6.7)\end{array}$ & $\begin{array}{l}14 \\
(2)\end{array}$ & 5.4 & AMPHO \\
\hline
\end{tabular}

*Half month.

Note: Standard deviation in ( ).

For example, one week of dilution of the ponds was lost during April because of the collapse of one of the cultures (a large dose of chlorine was measured in the make-up water). In general, the dilution rate may not have been fast enough to attain maximal productivities. On the other hand, last year we found that with $M$. minutum, responses to heating are minimal. This finding was again observed in the May experiments.

A heating experiment was performed using T. suecica TETRAI during June. Unlike the other experiments, this one was conducted sequentially and without replication. However, the average conditions of insolation and ambient temperature were quite uniform during this time. For 12 days in early June, a culture was heated to $20^{\circ} \mathrm{C} 24 \mathrm{~h}$ each day. For 11 days during the last two weeks of June, the culture was not heated. When we compared the results of these experiments, we found that productivity was 
Table 5-2. Productivity of Algal Strains Cultivated in $3-\mathrm{m}^{2}$ Ponds (1988)

\begin{tabular}{llccc}
\hline Species & \multicolumn{1}{c}{ Date } & $\begin{array}{c}\text { Insolation } \\
\left(\mathrm{cal} / \mathrm{cm}^{2} / \mathrm{d}\right)\end{array}$ & $\begin{array}{c}\text { Productivity } \\
\left(\mathrm{g} \mathrm{AFDM} / \mathrm{m}^{2} / \mathrm{d}\right)\end{array}$ & $\begin{array}{c}\text { Efficiency } \\
(\% \text { AR })\end{array}$ \\
\hline RTF CYCLO & $9 / 27-11 / 8$ & 389 & 20.3 & 7.0 \\
RTF AMPHO & $5 / 17-7 / 3$ & 608 & 30.9 & 6.8 \\
& $8 / 16-11 / 16$ & 420 & 20.7 & 6.6 \\
CHAET9 & $6 / 26-8 / 13$ & 552 & 20.6 & 5.0 \\
CHAET63 & $9 / 15-10 / 6$ & 476 & 18.5 & 5.2 \\
TETRA1 & $5 / 14-11 / 16$ & 506 & 18.4 & 4.8 \\
MONOR2 & $1 / 1-5 / 14$ & 427 & 7.9 & 2.5 \\
& $9 / 15-10 / 23$ & 435 & 15.7 & 4.8 \\
\hline
\end{tabular}

unchanged. The only noticeable difference was that the small amount of contamination of these cultures by Amphora was absent in the heated culture.

\subsubsection{Effects of Reduced $\mathrm{pCO}_{2}$}

Amphora sp. RTF, T. suecica TETRAl, and C. muelleri CHAET9 were grown at several $\mathrm{pHs}$ to test the effect on productivity of reducing the concentration of $\mathrm{CO}_{2}$ in the bulk liquid. Although the $\mathrm{pH}$ had to be raised to accomplish this, we assumed that with the values that tested higher, $\mathrm{pH}$ would not affect productivity (Weissman, in press). Three $\mathrm{pH}$ values were used. At $\mathrm{pH} 7.2, \mathrm{CO}_{2}$ concentration was about $285 \mu \mathrm{m}$; at $\mathrm{pH} 7.8$, it was $75 \mu \mathrm{m}$; and at $\mathrm{pH} 8.3$, it was about $20 \mu \mathrm{m}$. Thus, outgassing losses of $\mathrm{CO}_{2}$ could be significantly lowered by operating at a higher $\mathrm{pH}$.

The results of cultivation at different $\mathrm{pH}$ values are shown in Table 5-4. Productivity was significantly lower in a statistical sense ( $t$ test for difference of correlated means, data not shown). However, in a practical sense, the 10\%-15\% lower productivity at higher $\mathrm{pH}$ is not important. We will continue to study whether the difference remains small when such an experiment is performed at productivities above $30 \mathrm{~g} \mathrm{AFDM} / \mathrm{m}^{2} / \mathrm{d}$.

\subsubsection{Effect of Rate of Dilution}

T. suecica TETRA1 and Amphora RTF were grown in continuous culture with either $35 \%$ or $50 \%$ of the volume diluted per day. As shown in Table 5-5, no significant difference in the yield occurred in either case. However, the slower rate of dilution is more stable in a climate with variable insolation. The slower rate of dilution allows the pond to maintain a standing biomass during cloudy days.

\subsubsection{Growth under Nitrogen or Silicon Deficiency}

A number of experiments were performed to monitor production of biomass and lipids under nutrient-deficient conditions. Nutrient-sufficient biomass was taken from continuously diluted cultures, diluted with nitrogen-free or silicon-free growth medium, and allowed to grow in batch. Sampling was made daily. The cell density (and thus, time) at 

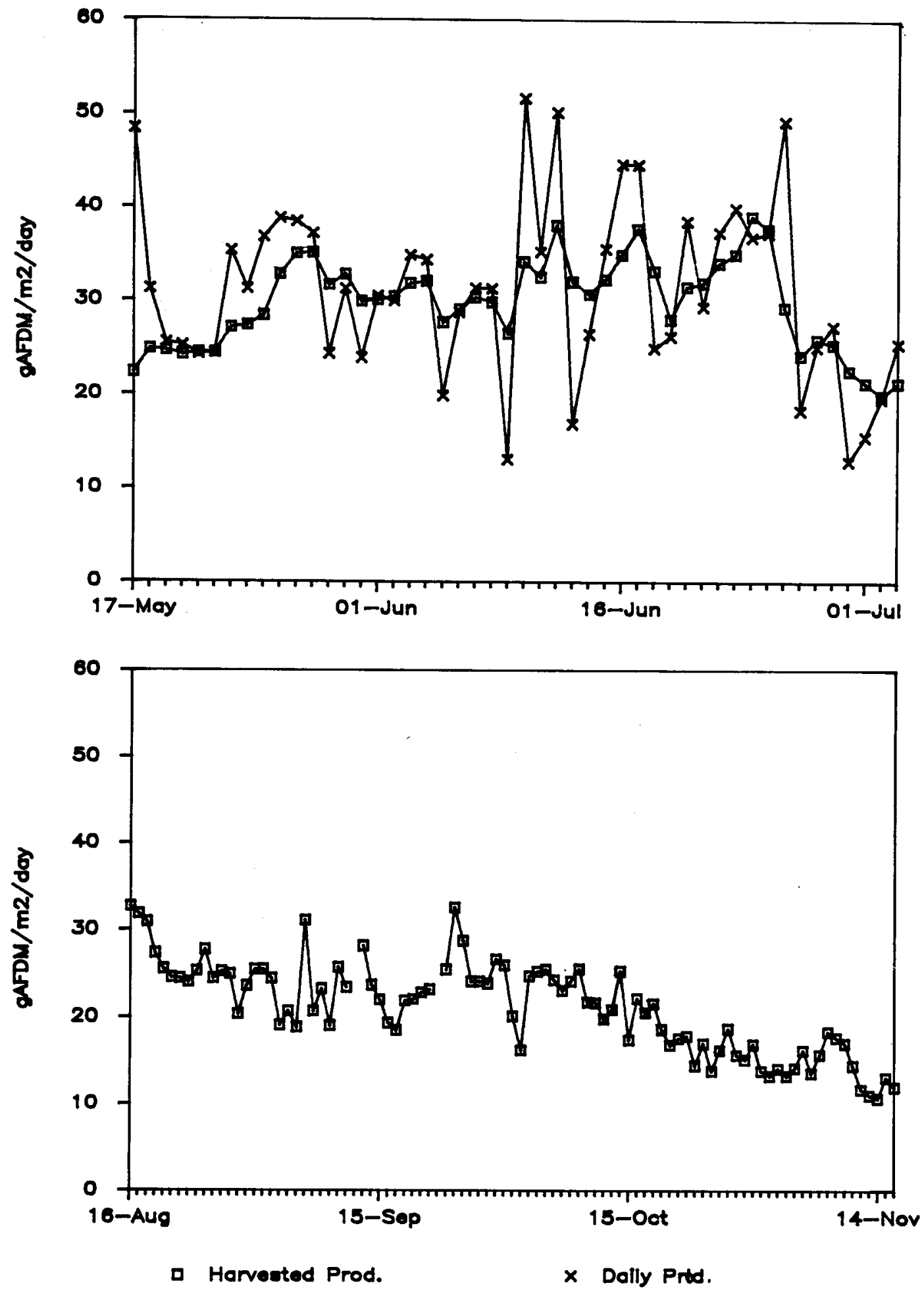

Figure 5-4. Productivity of Amphora sp. RTF

Dilution was continuous with approximately $35 \%$ of the pond volume removed each day. 

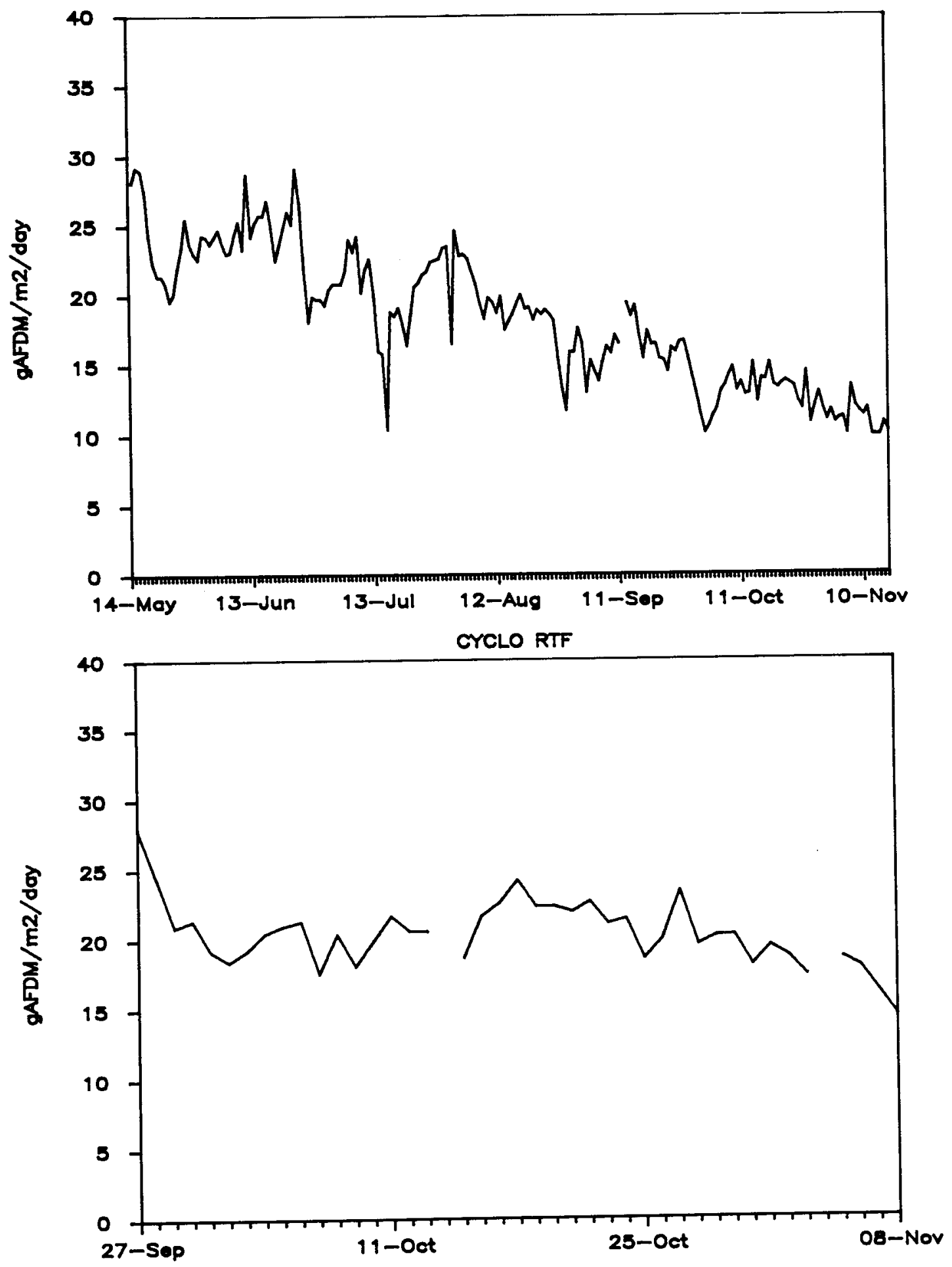

Figure 5-5. (a) Harvested productivity of T. suecica TETRA1

(b) Harvested productivity of Cyclotella sp. RTF

Dilution was continuous at $35 \%$ removed per day 

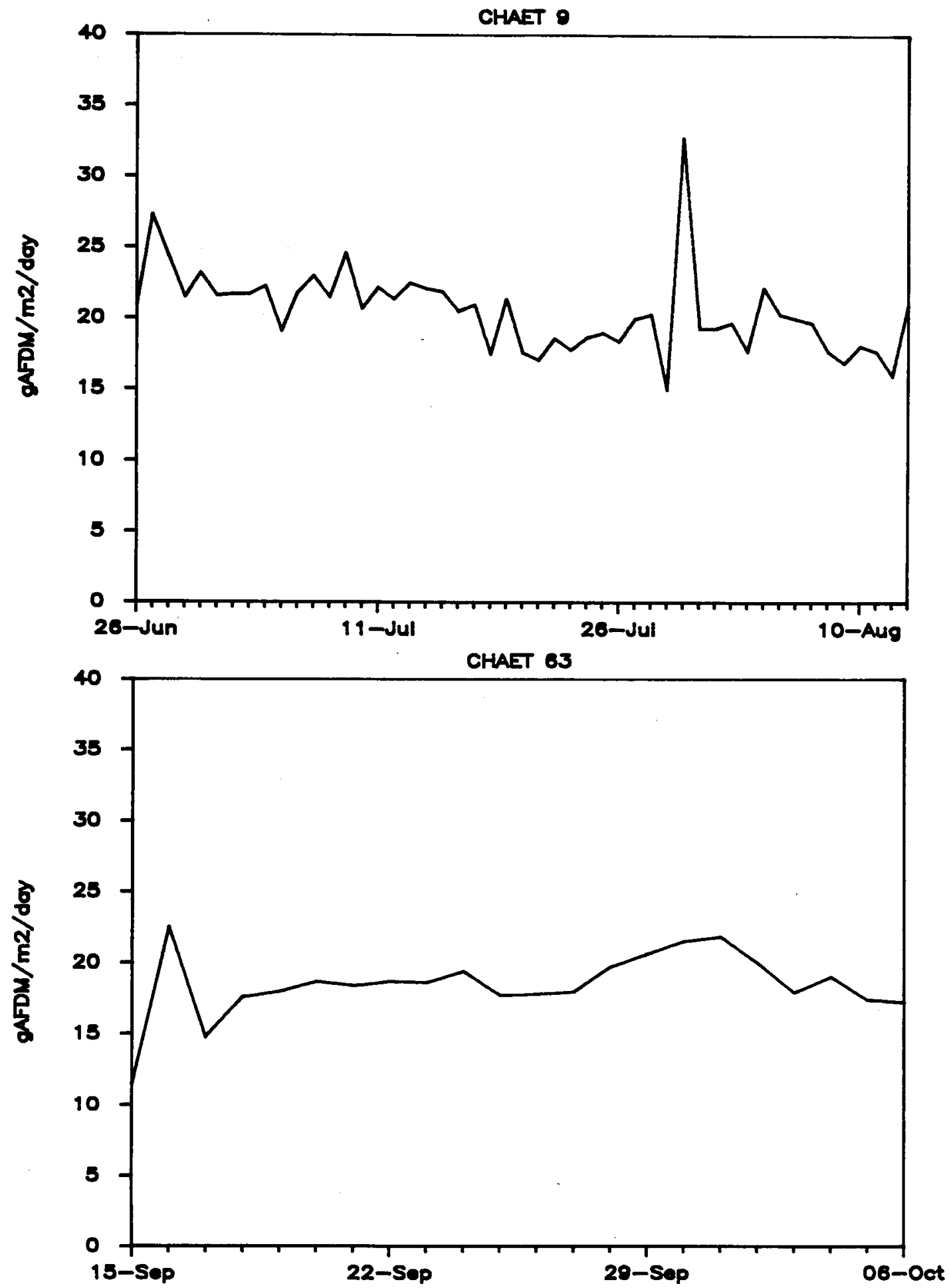

Figure 5-6. (a) Harvested productivity of C. muellera CHAET9

(b) Harvested productivity of $C$. muelleri CHAET63

Dilution was continuous at $35 \%$ removed per day. 

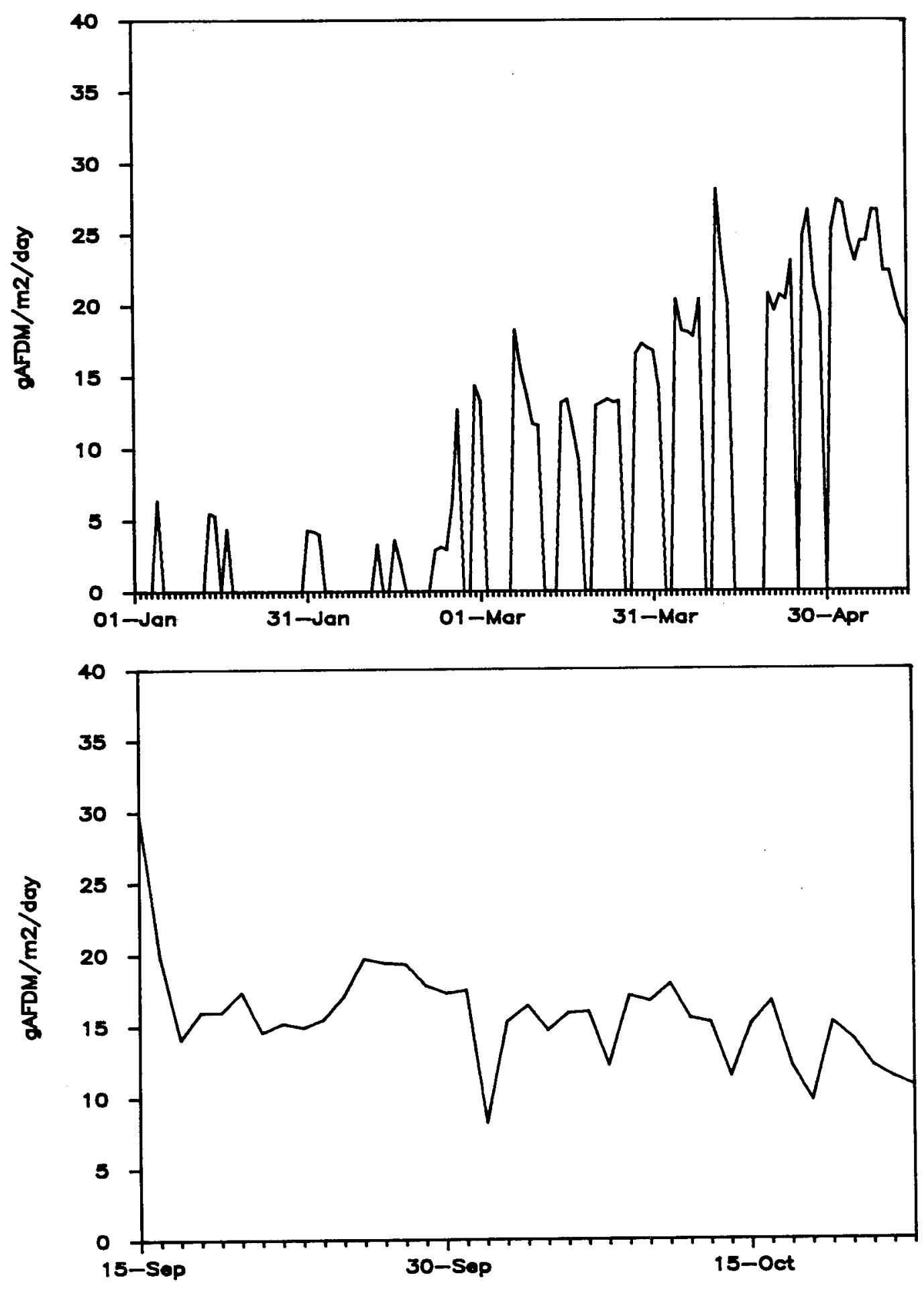

Figure 5-7. Harvested productivity of $M$. minutum MONOR2

Gaps represent periods of time when ponds were not diluted; thus, there was no harvested productivity. 
Table 5-3. Effects of Heating on Algal Productivity in $3-\mathrm{m}^{2}$ Ponds

\begin{tabular}{|c|c|c|c|c|c|c|c|}
\hline \multirow{3}{*}{ Month } & \multicolumn{4}{|c|}{ Temperature } & \multicolumn{2}{|c|}{ Productivity } & \multirow{3}{*}{ Species } \\
\hline & \multirow{2}{*}{$\frac{\begin{array}{c}\text { Heated } \\
\max \left({ }^{\circ} \mathrm{C}\right)\end{array}}{21.5}$} & \multirow{2}{*}{$\begin{array}{l}\text { Pond } \\
\min \left({ }^{\circ} \mathrm{C}\right) \\
0\end{array}$} & \multicolumn{2}{|c|}{$\begin{array}{l}\text { Unheated Pond } \\
\max \left({ }^{\circ} \mathrm{C}\right) \min \left({ }^{\circ} \mathrm{C}\right)\end{array}$} & \multicolumn{2}{|c|}{$\begin{array}{l}\text { Heated Unheated } \\
\left.\text { (g AFDM } / \mathrm{m}^{2} / \mathrm{d}\right)\end{array}$} & \\
\hline & & & 7.1 & $<0$ & 3.05 & 0.8 & \\
\hline Feb. & 24.6 & 1.5 & 9.6 & 0 & 3.3 & 1.95 & MONOR2 \\
\hline $\begin{array}{l}\text { Apr. } \\
\text { R2 }\end{array}$ & 23.6 & 5.7 & 21.8 & 4.4 & 12.6 & 11.9 & MONO \\
\hline $\begin{array}{l}\text { May } \\
1-14\end{array}$ & 27.9 & 10.9 & 25.0 & 7.1 & 23.8 & 26.2 & MONOR2 \\
\hline $\begin{array}{l}\text { May } \\
14-23\end{array}$ & 29.0 & 12.0 & 27.1 & 11.7 & 25.2 & 28.3 & TETRA 1 \\
\hline $\begin{array}{l}\text { June } \\
4-15\end{array}$ & 30.5 & 19.5 & 29.7 & 13.7 & 24.6 & -- & TETRAI \\
\hline $\begin{array}{l}\text { June } \\
15-25\end{array}$ & -- & -- & 30.3 & 15.3 & -- & 25.2 & TETRAI \\
\hline
\end{tabular}

Table 5-4. Effects of $\mathrm{pCO}_{2}$ on Productivity (g AFDM $/ \mathrm{m}^{2} / \mathrm{d}$ )

\begin{tabular}{llcc}
\hline Species & $\mathrm{PCO}_{2}$ & Productivity & $\mathrm{n}$ \\
\hline RTF AMPHO & 0.0090 & $24.0(2.0)$ & 5 \\
& 0.0024 & $22.6(2.6)$ & \\
CHAET63 & 0.0090 & $19.0(1.7)$ & 14 \\
& 0.0006 & $16.8(1.7)$ & \\
TETRA1 & 0.0090 & $21.3(1.6)$ & 15 \\
& 0.0024 & $18.1(1.3)$ & \\
TETRA1 & 0.0090 & $19.5(3.4)$ & 18 \\
& 0.0006 & $16.5(1.0)$ &
\end{tabular}

Note: $\mathrm{PCO}_{2}$ of $0.0090,0.0024$, and 0.0006 correspond to $\mathrm{pH} 7.2,7.8$, and 8.3 , respectively. $0.01 \mathrm{~atm}=320 \mu \mathrm{m}$.

Standard deviation given in ( ). 
Table 5-5. Effects of Dilution Rate on Productivity $\left(\mathrm{g} \mathrm{AFDM} / \mathrm{m}^{2} / \mathrm{d}\right)$

\begin{tabular}{lccc}
\hline Species & $\begin{array}{c}\text { Detention Time } \\
\text { (days) }\end{array}$ & Productivity & $\mathrm{n}$ \\
\hline RTF AMPHO & 3 & $30.9(2.6)$ & 19 \\
& 2 & $30.3(3.9)$ & -- \\
TETRA1 & 3 & $23.4(1.5)$ & 19 \\
& 2 & $21.2(2.3)$ & -- \\
\hline
\end{tabular}

Note: Standard deviation given in ( ).

which the cultures reduced intracellular nutrients below levels typical of nutrient sufficiency was estimated from the initial concentration of nutrient (that is, by diluting nutrient-sufficient medium plus any additions). Nitrogen sufficiency was assumed to end when biomass nitrogen content dropped below $8 \%$, and silicon sufficiency was assumed to end when biomass silicon content dropped to $20 \%$. The experiment was terminated when calculated intracellular nutrient concentration reached half of its sufficiency value. Lipid samples were saved for subsequent analysis at SERI.

The effect of nutrient deficiency on biomass productivity is shown in Table 5-6 and Figures 5-8 through 5-13. Without the nutrient analyses, it is difficult to determine where the optimal stopping point of the induction should be, as well as to what extent the lipid productivity increased or decreased. In general, the biomass productivities of the induction batches were less than concurrently operated, nutrient-sufficient continuous cultures, even before the nutrient became limiting. An experiment with $T$. suecica was the only exception perhaps because the cultures were both too dilute for optimal production at the beginning of the batches, and then not adapted to the shade conditions as the batches got denser (Weissman and Goebel, 1988). Setting the initial conditions of an induction batch will prove to be an important controlling factor. For the most part, biomass productivity dropped after nutrient-sufficient growth turned to nutrient-limiting growth. 
Table 5-6. Productivities of Nutrient-sufficient and-deficient Algal Cultures (g AFDM $/ \mathrm{m}^{-2} / \mathrm{d}$ )

\begin{tabular}{|c|c|c|c|c|}
\hline Species & $\begin{array}{l}\mathrm{N} \text { - or Si-sufficient } \\
\text { Continuous Cultures }\end{array}$ & Before Depletion & $\begin{array}{l}\text { Induction Batch } \\
\text { After Depletion }\end{array}$ & Overall \\
\hline $\begin{array}{l}\text { CHAET63 } \\
\text { Nitrogen } \\
\text { Nitrogen }\end{array}$ & $\begin{array}{l}18 \\
20\end{array}$ & $\begin{array}{l}9.8(4)^{*} \\
14.2(3)\end{array}$ & $\begin{array}{l}13.4(5-7)^{* * *} \\
19.2(4-6)\end{array}$ & $\begin{array}{l}11.4 \\
12.2\end{array}$ \\
\hline $\begin{array}{l}\text { CHAET9 } \\
\text { Nitrogen } \\
\text { Nitrogen }\end{array}$ & $\begin{array}{l}22 \\
22\end{array}$ & $\begin{array}{l}15.4(2) \\
17.6(2)\end{array}$ & $\begin{array}{l}14.4(3-4) \\
12.0(3-4)\end{array}$ & $\begin{array}{l}14.9 \\
14.8\end{array}$ \\
\hline $\begin{array}{l}\text { MONOR2 } \\
\text { Nitrogen } \\
\text { Nitrogen }\end{array}$ & $\begin{array}{l}16 \\
13\end{array}$ & $\begin{array}{l}6.9(5) \\
7.9(5)\end{array}$ & $\begin{array}{l}8.6(6) \\
2.1(6)\end{array}$ & $\begin{array}{l}7.2 \\
6.3\end{array}$ \\
\hline $\begin{array}{l}\text { RTF CYCL } \\
\text { Nitrogen } \\
\text { Nitrogen } \\
\text { Silicon }\end{array}$ & $\begin{array}{l}22 \\
20 \\
20\end{array}$ & $\begin{array}{l}16.4(2) \\
12.2(3) \\
16.4(3)\end{array}$ & $\begin{array}{l}16.1(3-5) \\
12.1(3-5) \\
13.8(4-7)\end{array}$ & $\begin{array}{l}16.2 \\
12.1 \\
14.1\end{array}$ \\
\hline $\begin{array}{l}\text { TETRA1 } \\
\text { Nitrogen } \\
\text { Nitrogen } \\
\text { Nitrogen }\end{array}$ & $\begin{array}{l}26 \\
24 \\
16\end{array}$ & $\begin{array}{l}19.1(5) \\
22.5(3) \\
20.5(3)\end{array}$ & $\begin{array}{c}13.6(6-7) \\
13.7(4-6) \\
9.8(4-10)\end{array}$ & $\begin{array}{l}17.5 \\
18.1 \\
13.8\end{array}$ \\
\hline $\begin{array}{l}\text { RTF AMPH } \\
\text { Nitrogen } \\
\text { Nitrogen } \\
\text { Nitrogen } \\
\text { Silicon } \\
\text { Silicon }\end{array}$ & $\begin{array}{l}40 \\
37 \\
27 \\
38 \\
35\end{array}$ & $\begin{array}{l}21.4(2) \\
21.2(2) \\
20.3(3) \\
15.5(1) \\
19.2(2)\end{array}$ & $\begin{array}{l}13.1(3-7) \\
12.1(3-4) \\
8.0(4) \\
8.2(2) \\
5.1(3-4)\end{array}$ & $\begin{array}{l}15.5 \\
16.7 \\
17.2 \\
11.8 \\
12.2\end{array}$ \\
\hline
\end{tabular}

* Number of days of nutrient-sufficient growth.

* Day of change to nutrient-deficient growth minus last day of experiment

Note: Biomass is nutrient sufficient until depletion of nutrient from medium. 

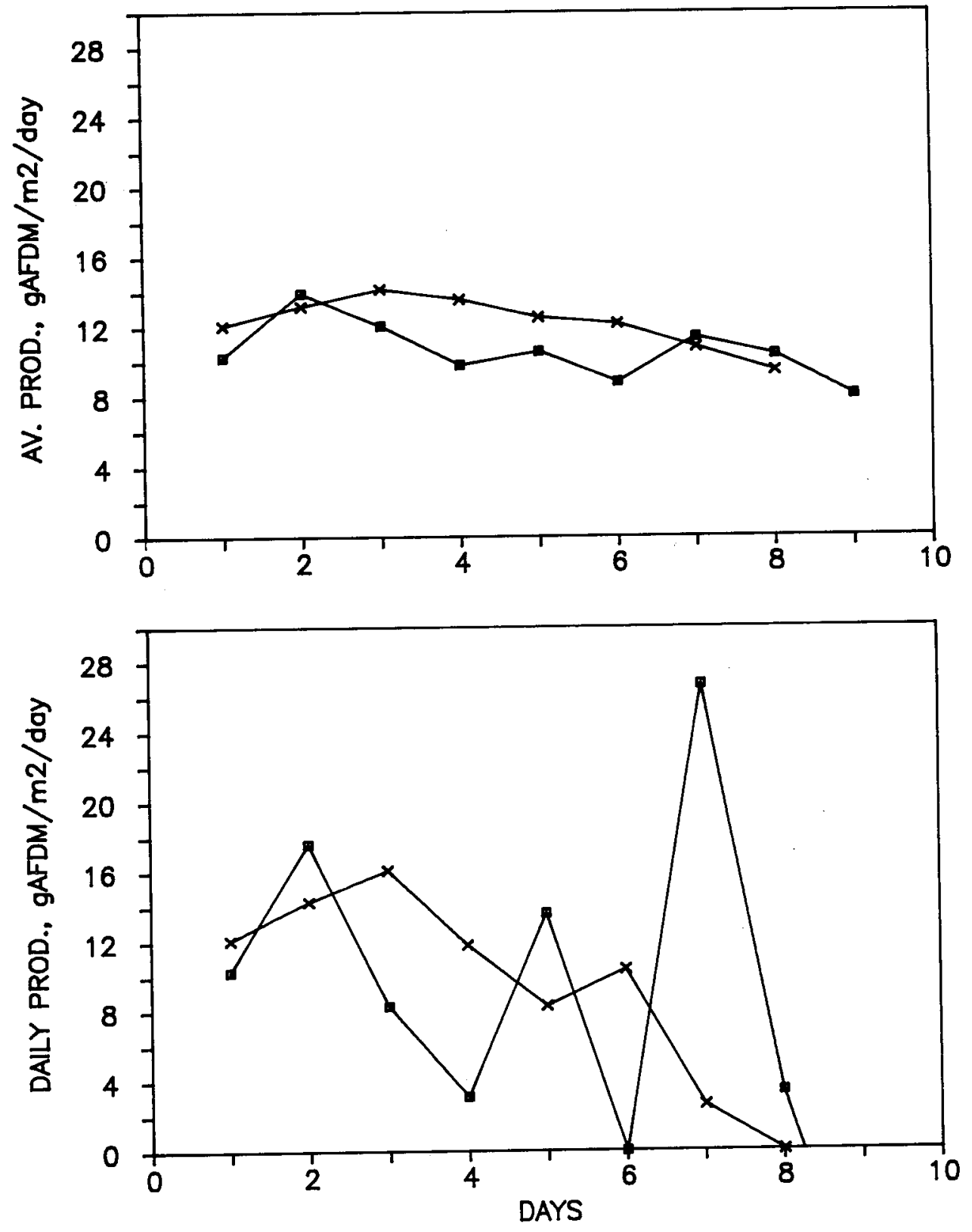

Figure 5-8. Productivity of nitrogen-depleted induction batches of C. muelleri CHAET63

Nutrient-sufficient growth ceased after day 3 (crosses) or day 4 (boxes) 

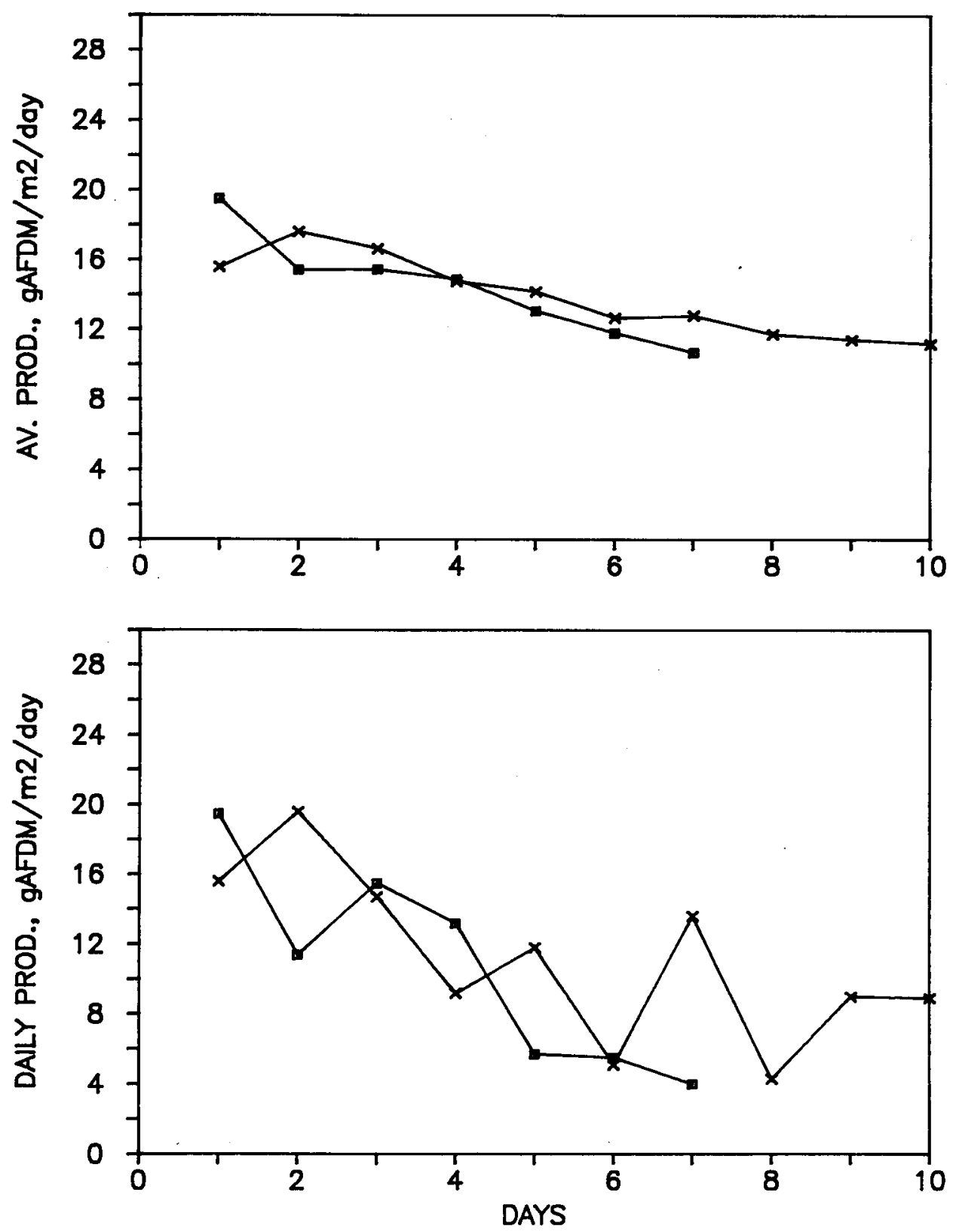

Figure 5-9. Productivity of nitrogen-depleted induction batches of C. muelleri CHAET9

Nutrient-sufficient growth ceased between days 1 and 2 in both experiments 

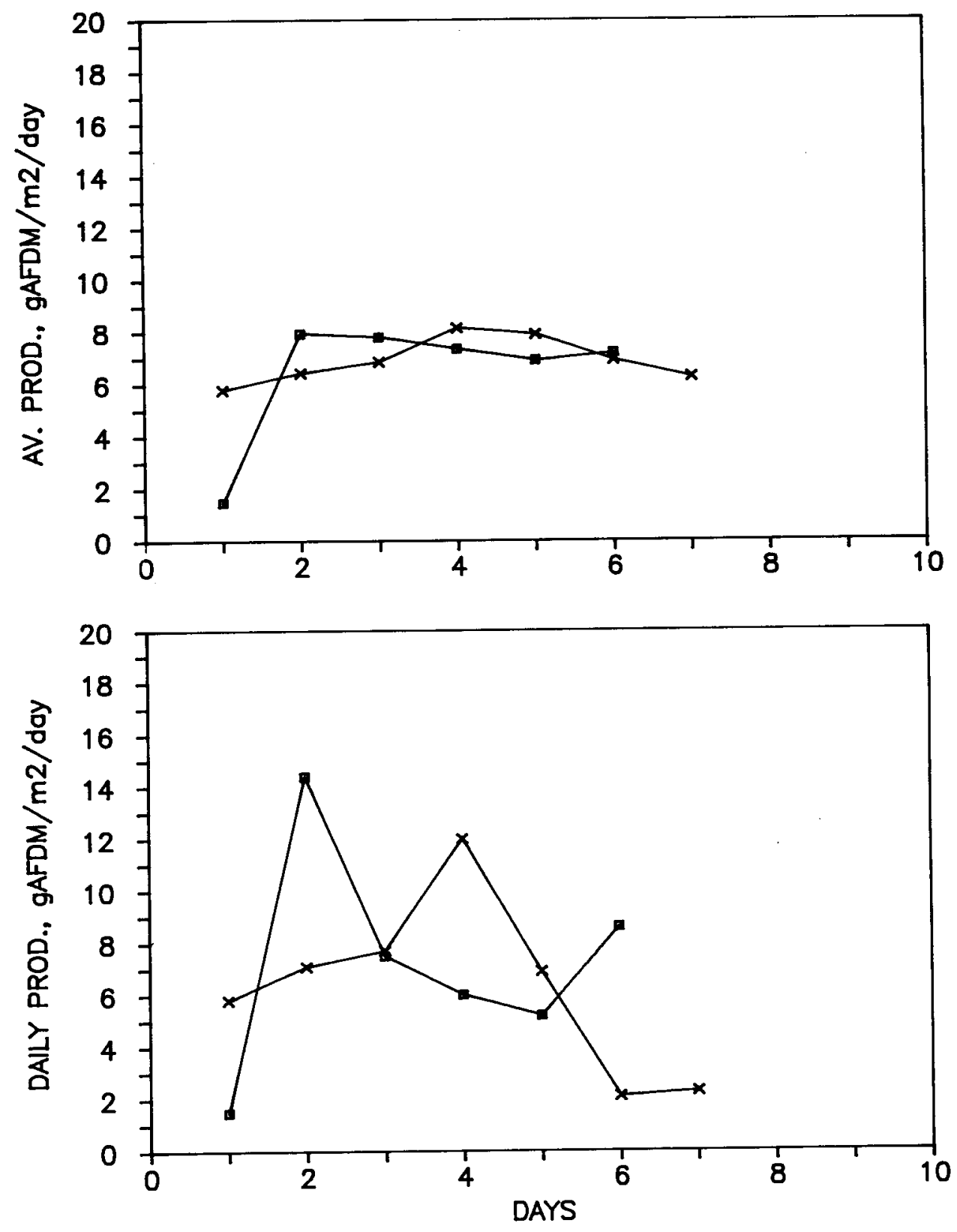

Figure 5-10. Productivity of nitrogen-depleted induction batches of M. minutum MONOR2

Nutrient-sufficient growth ceased after day 5 in both experiments 

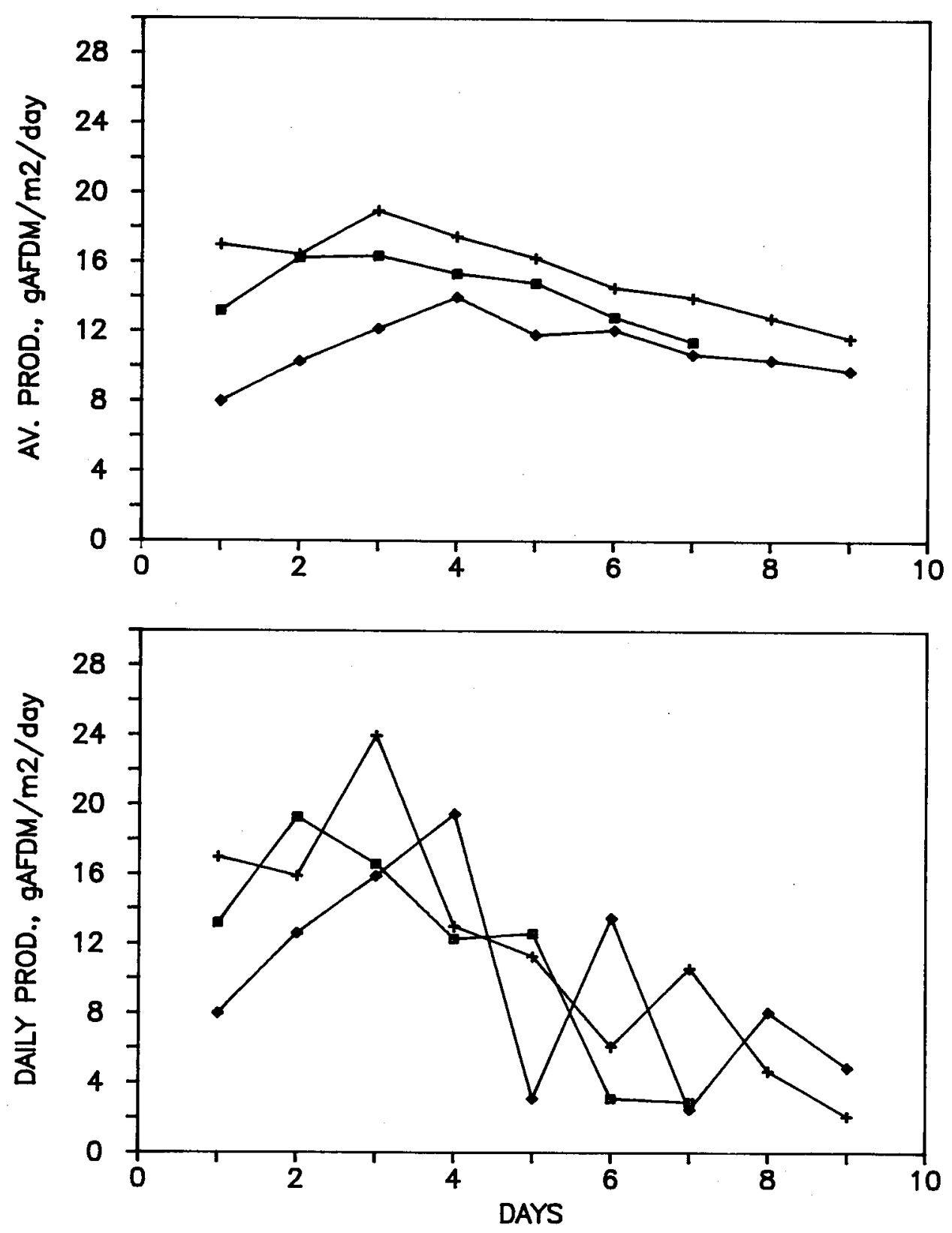

Figure 5-11. Productivity of nutrient-depleted induction batches of Cyclotella sp. RTF

Nitrogen-sufficient growth ceased after day 2 (pluses) or day 3 (diamonds). Silicon-sufficient growth ceased after day 3 (boxes) 

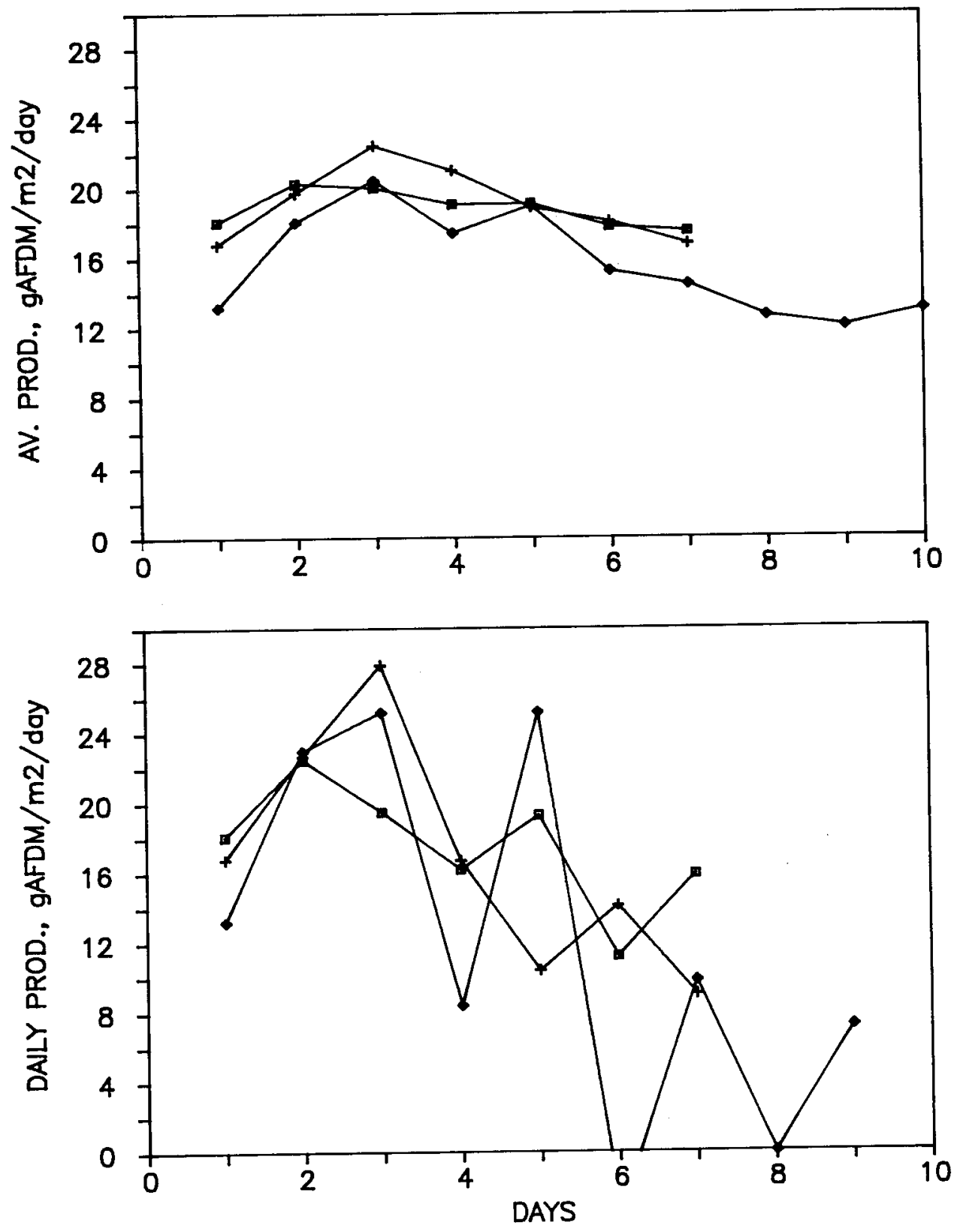

Figure 5-12. Productivity of nitrogen-depleted induction batches of T. suecica TETRA1 Nitrogen-sufficient growth ceased after day 3 (pluses and diamonds) or after day 5 (boxes). 

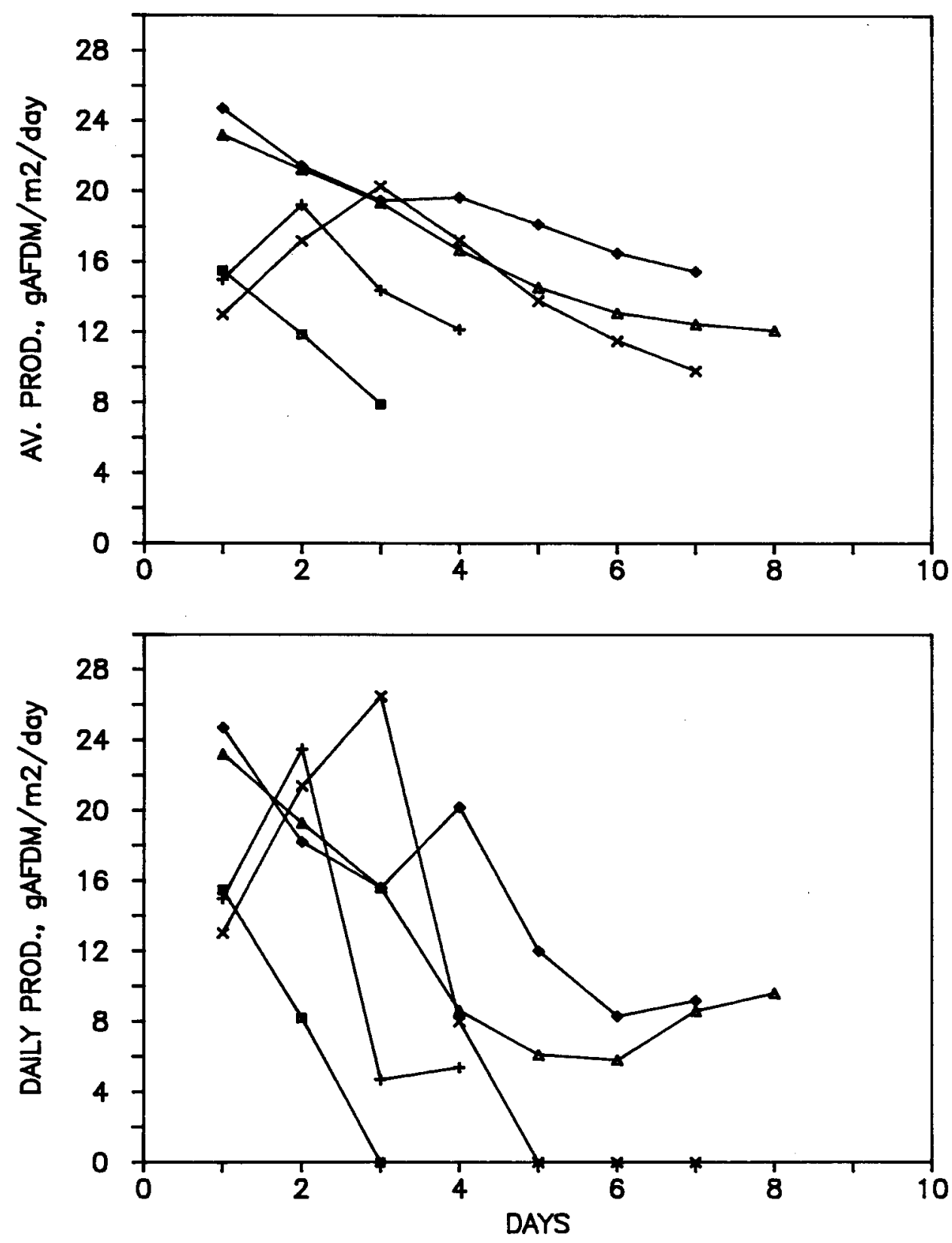

Figure 5-13. Productivity of nutrient-depleted induction batches of Amphora sp. RTF

Nitrogen-sufficient growth ceased after day 2 (diamonds and triangles) or day 3 (crosses). Silicon-sufficient growth ceased after day 1 (boxes) or day 2 (pluses). 


\subsection{CONCLUSIONS AND FUTURE WORK}

Several important conclusions can be reached based on the data collected. The use of equations for uniform flow in open channels in the design of large raceways (Weissman et al., 1988b) is justified and practical when adjustments are made for head losses not associated with channel roughness. For the 0.1 -ha raceways, these additional losses were just as significant as those due to the pond bottom. Even for larger raceways, the design of the slope and the mixing system must be modified to accommodate increased losses caused by bends and sumps. From the overall mixing system efficiencies, it is evident that before a larger pond system is built, the design-mixing velocity must be specified rather closely. Otherwise, power consumed for mixing will be much greater than actually needed to satisfy the hydraulic power consumption. In terms of operating large raceways, the data indicate that operation will be easier and more economical if the design depth is larger than the present operating depth of $14 \mathrm{~cm}$. During most of 1989 , the operating depth will be increased to $18-20 \mathrm{~cm}$. If lower depths are desired, then grading costs will certainly increase greatly for large pond construction.

The methods used for measuring velocity and power were chosen as a compromise between precision and accuracy on the one hand, and cost (both for instruments and time) on the other. The methods are adequate, but the degree of error limits the scope of the analysis. At present, we do not plan to spend more funds to significantly lower the measurement errors. However, when the next set of measurements are taken, the pond depth will be greater. This should improve the precision of all depth measurements and reduce the influence of depth variations on velocity and kinetic energy measurements. Thus, operation at greater depth will not only improve hydraulics, but also improve hydraulic measurements. At that time, we will determine whether to improve the grade of the system by filling low spots with sand. This determination will be based on cost, convenience, and whether the increased depth results in sufficient improvement in hydraulics.

The analysis of the carbonation system indicates that although injection efficiency is good, averaging above $80 \%$ in the tests, it needs to be as high as $90 \%$. Carbon is one of the most critical cost centers in the technology. In the $3-\mathrm{m}^{2}$ ponds we found that losses via outgassing can be kept minimal by operating at $\mathrm{pH} 8$ and above. The impact on biomass productivity appeared to be small. This finding must be confirmed at the highest rates of production. The errors in the carbonation sump tests also need to be reduced. This will be accomplished by measuring actual total inorganic carbon in the water, rather than by estimating it with buffer equations.

The performance of the 0.1-ha raceways was hampered by start-up problems. Depths were too shallow for the uneven grade, leading to excessive in-pond settling of cells; operations were interrupted to reexamine some of the engineering measurements; and adjustments in baffling were ongoing to improve hydraulics. Some of these problems cannot be avoided in a research environment. Improvements need to be tested. However, emphasis will be placed on reducing in-pond settling because its effects on yield are serious.

Annually averaged biomass, yields, estimated on the basis of performance in the $3-\mathrm{m}^{2}$ ponds, were $16 \mathrm{~g} \mathrm{AFDM} / \mathrm{m}^{2} / \mathrm{d}$. The months of March and April are being targeted for yield improvement. Insolation is high, although temperatures are variably cool. If a strain can be found that grows well in the large raceways during these months, in addition to the kind of grqwth achieved during the summer, then productivity average will exceed $20 \mathrm{~g} \mathrm{AFDM} / \mathrm{m}^{2} / \mathrm{d}$. We have evidence of much greater yields for very short periods. At present, there is virtually no understanding why yield can be above $50 \mathrm{~g} \mathrm{AFDM} / \mathrm{m}^{2} / \mathrm{d}$ on isolated days. In the future, research needs to be conducted to elucidate the conditions favorable for such high yields. 


\subsection{REFERENCES}

Barclay, W.R., K.L. Terry, N.J. Nagle, J.C. Weissman, and R.P. Goebel, 1987, "Potential of New Strains of Marine Inland Saline-Adapted Microalgae for Aquaculture," J. World Aquaculture Soc., Vol. 18, pp. 218-228.

Daugherty, R.L., and J.B. Franzini, 1977, Fluid Mechanics with Engineering Applications, New York: McGraw-Hill.

Loewenthal, R.E., and C.V.R. Marais, 1984, Carbonate Chemistry of Aquatic Systems: High Salinity Waters, Boston: Butterworths.

Neenan, B., D. Feinberg, A. Hill, R. Mclntosh, and K. Terry, 1986, Fuels from Microalgae: Technology Status, Potential, and Research Requirements, SERI/SP-231-2550, Golden, CO: Solar Energy Research Institute.

Stumm, W., and J.J. Morgan, 1980, Aquatic Chemistry, New York: John Wiley \& Sons.

Weissman, J.C., and R.P. Goebel, 1985, Production of Liquid Fuels and Chemicals by Microalgae, Final Report, SERI/STR-231-2649, Golden, CO: Solar Energy Research Institute.

Weissman, J.C., and R.P. Goebel, 1987, Design and Analysis of Microalgal Open Pond Systems for the Purpose of Producing Fuels, Final Report, SERI/STR-231-2840, Golden, CO: Solar Energy Research Institute.

Weissman, J.C., and R.P. Goebel, 1988, Production of Liquid Fuels and Chemicals by Microalgae, Final Report, \#XK-3-030135-1, Golden, CO: Solar Energy Research Institute.

Weissman, J.C., R.P. Goebel, and D.M. Tillett, 1988a, Design and Operation of an Outdoor Microalgae Test Facility, Final Report, Subcontract XK-1-06113-1, Golden, CO: Solar Energy Research Institute.

Weissman, J.C., R.P. Goebel, and J.R. Benemann, 1988b, "Photobioreactor Design: Mixing, Carbon Utilization, and Oxygen Accumulation," Biotechnol. Bioeng., Vol. 31, pp. 336-344. 


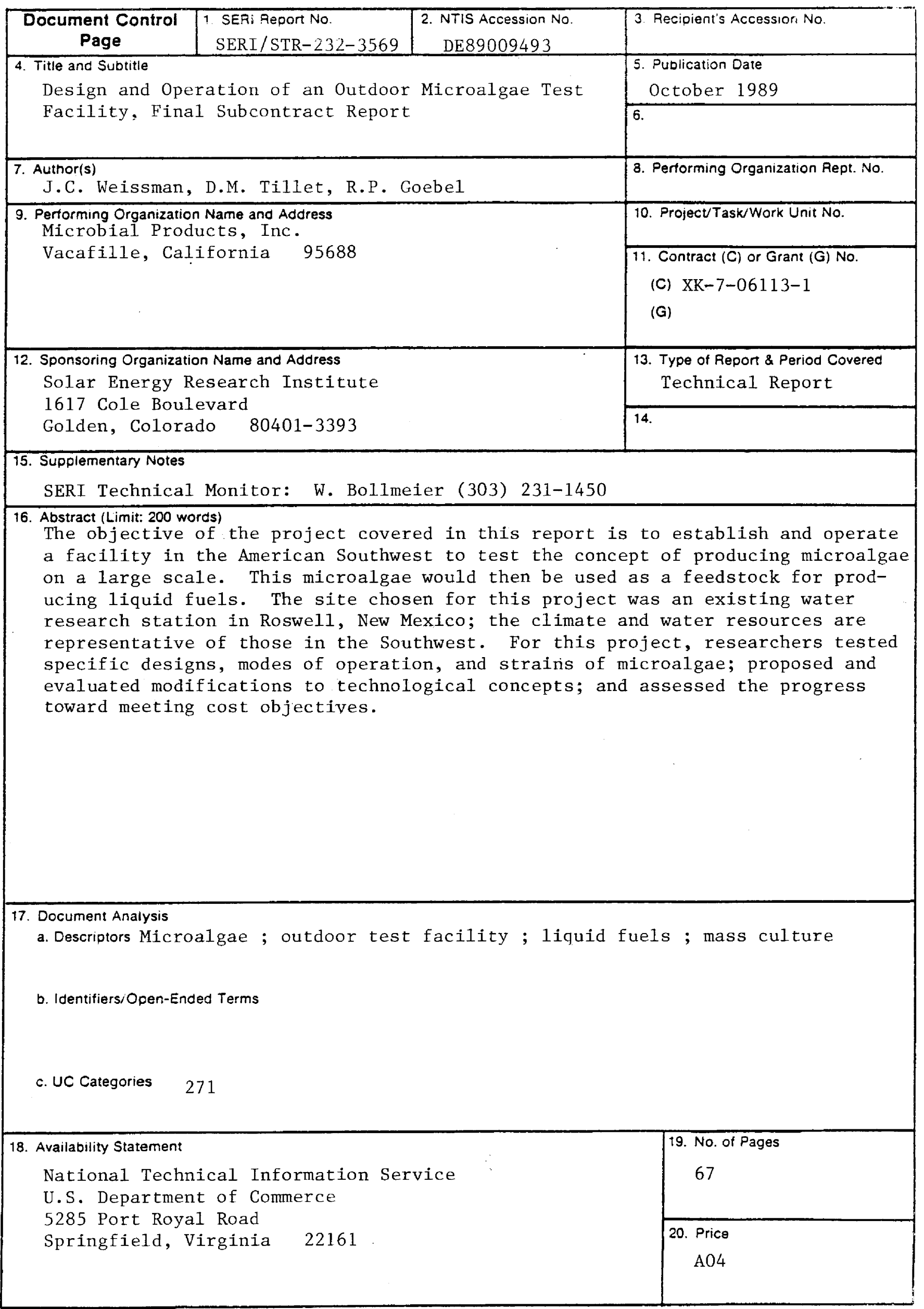

